\title{
OPEN SMART CITIES IN CANADA: ASSESSMENT REPORT
}

\author{
$\frac{\sqrt{1}}{312}$ \\ $\begin{array}{ll}\text { Natural Resources } & \begin{array}{l}\text { Ressources naturelles } \\ \text { Canada }\end{array} \\ \text { Canada }\end{array}$ \\ Canadà
}

OpenNorth 


\section{Publishing and Licensing Information}

Prepared by Rachel Bloom (OpenNorth), Professor Tracey P. Lauriault (Carleton University), and Jean-Noé Landry (OpenNorth).

\section{OpenNorth 2018.}

This work is licensed under an Attribution-NonCommercial-ShareAlike 4.0 International License (CC BY-NC-SA 4.0).

$$
\text { (c) (i) } 8 \text { (9) }
$$

\section{Publication History}

First published in April 2018.

Amendments issued since publication

Date Updated text 


\section{Contents}

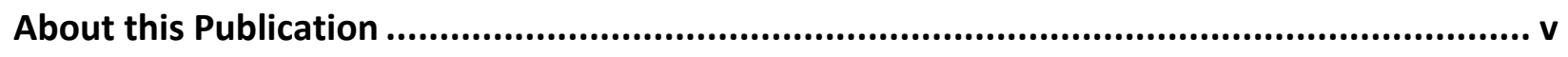

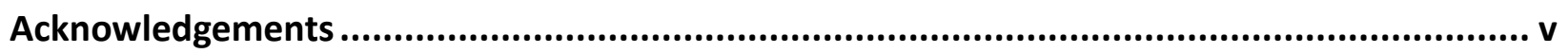

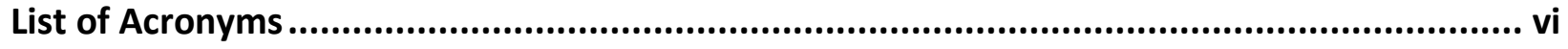

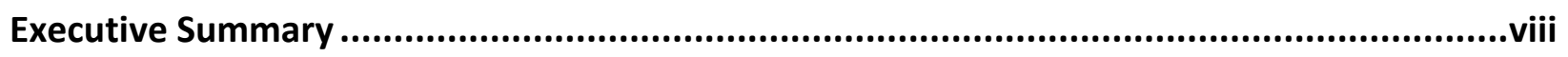

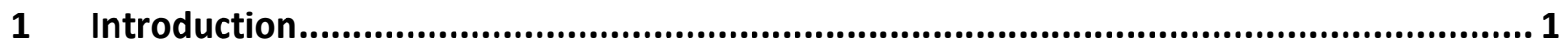

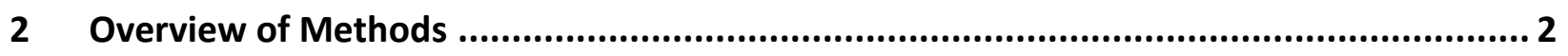

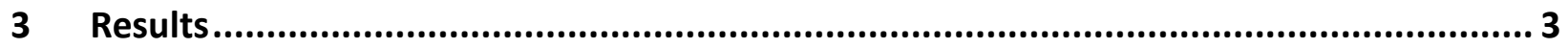

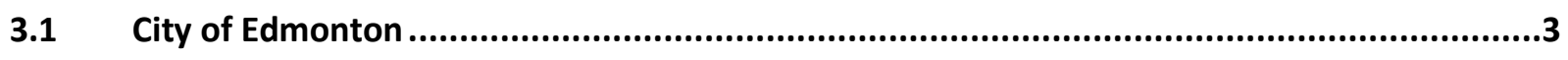

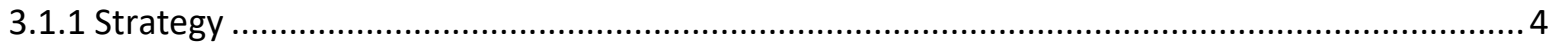

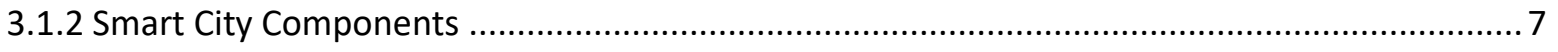

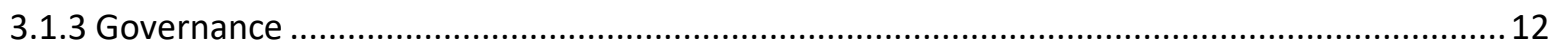

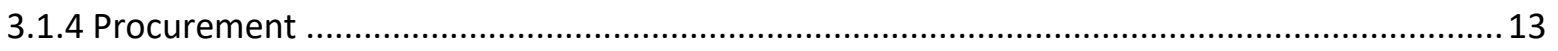

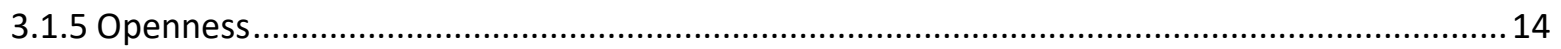

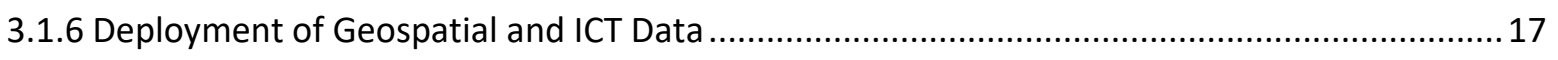

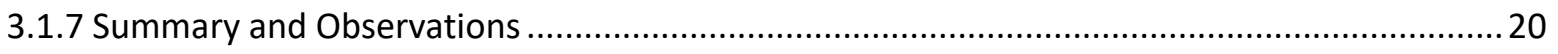

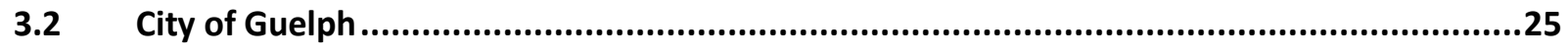

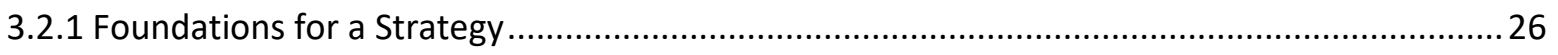

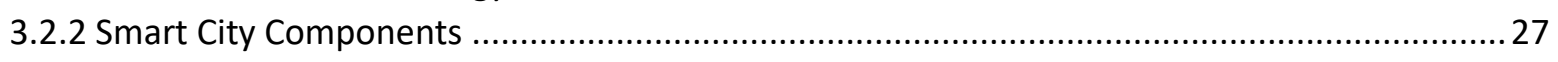

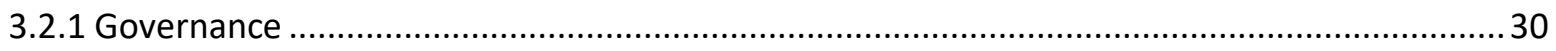

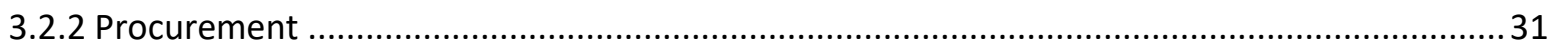

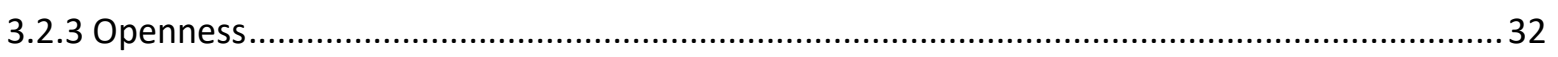

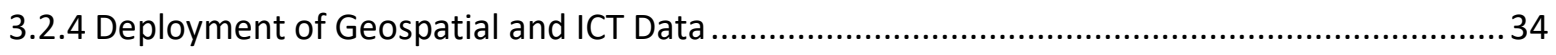

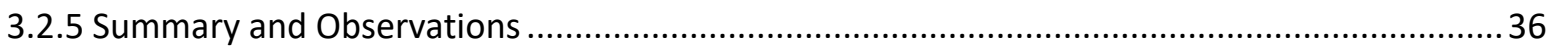

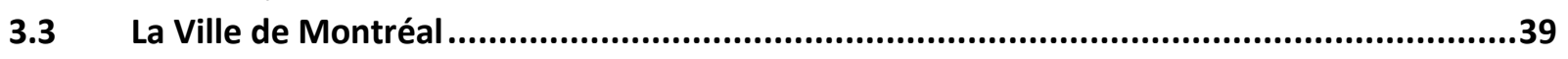

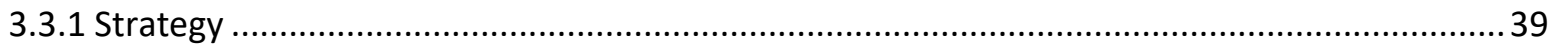

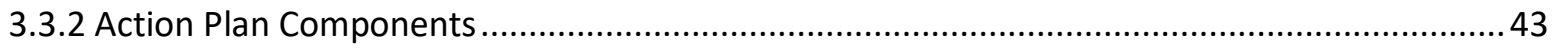

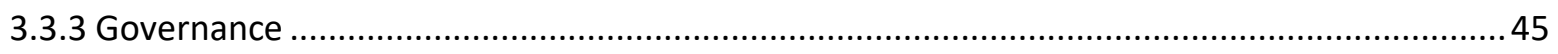

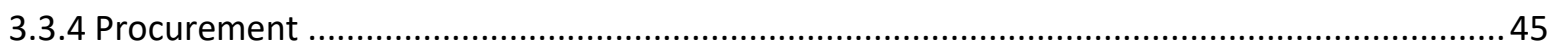

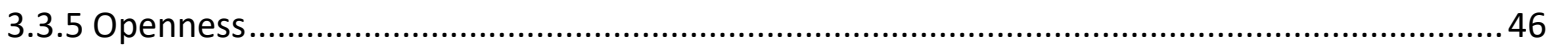

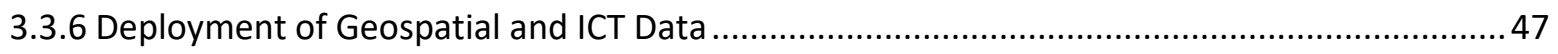

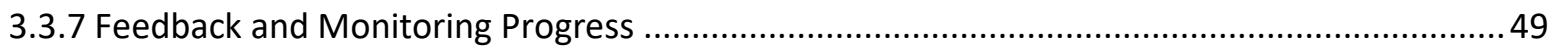

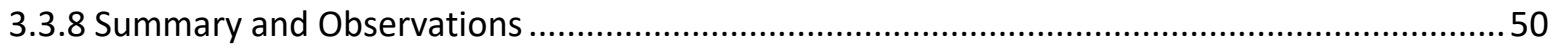

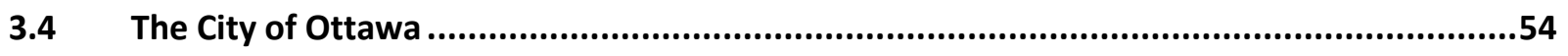

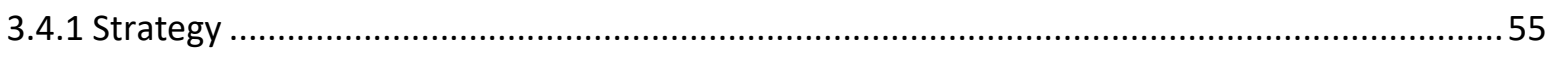

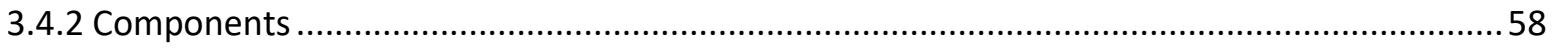

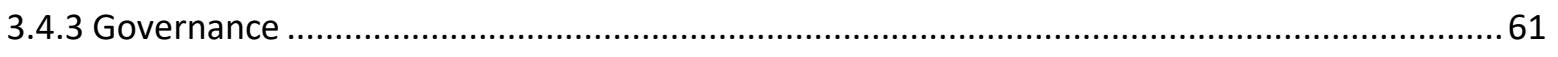

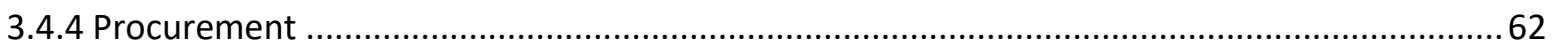

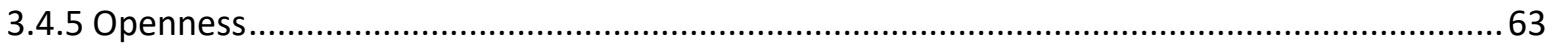

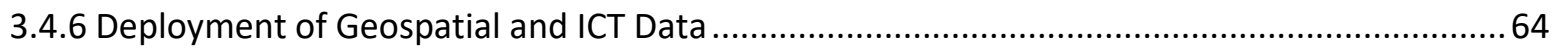




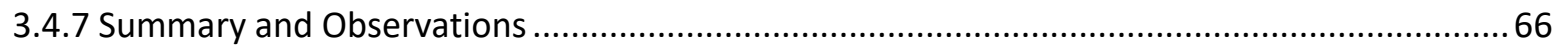

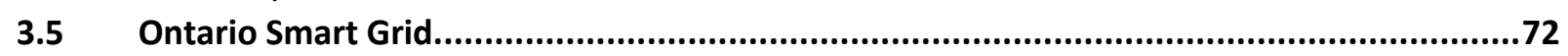

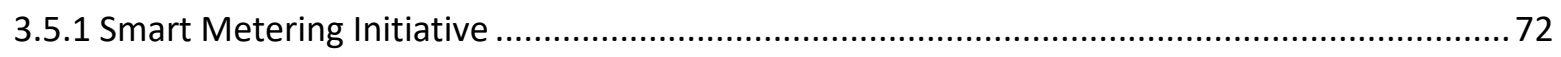

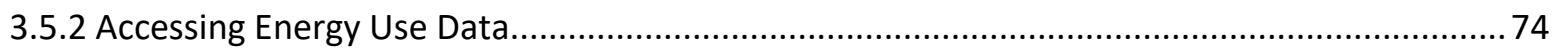

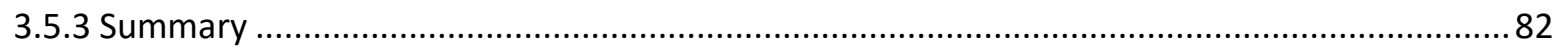

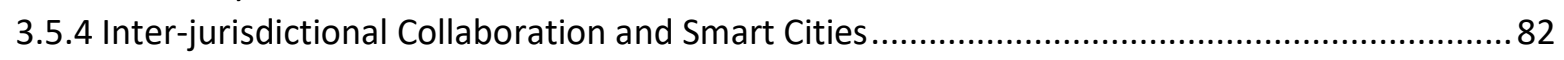

Appendix A: Edmonton's Smart City Strategy (2017) .............................................................. 84

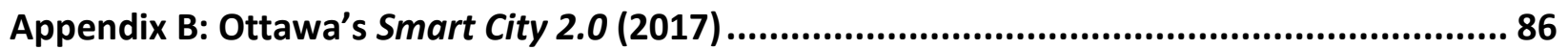




\section{List of Figures}

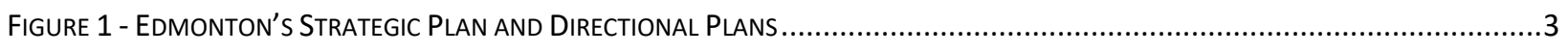

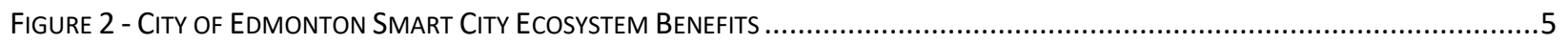

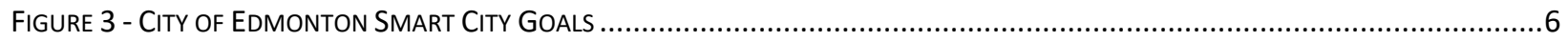

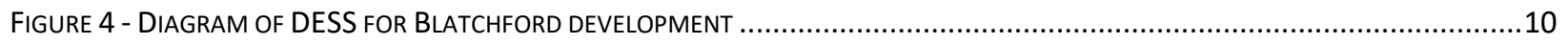

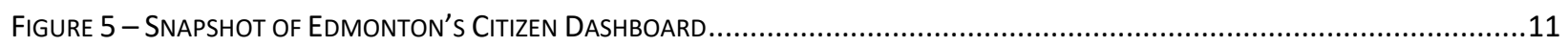

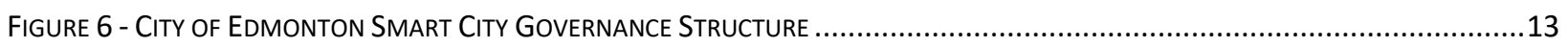

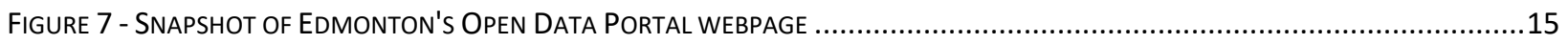

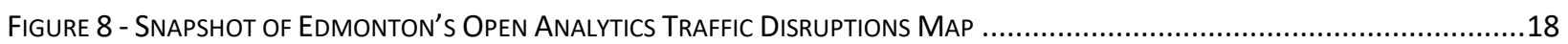

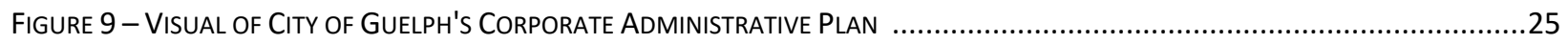

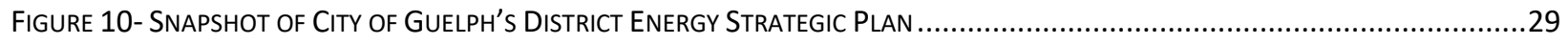

FIgURE 11 - SNAPSHOt OF CITY OF GUELPH'S PERFORMANCE REPORTING DASHBOARD (BETA-VERSION) .......................................30

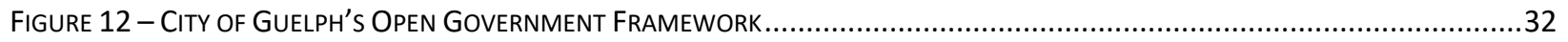

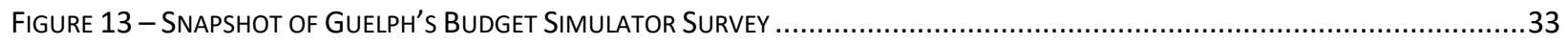

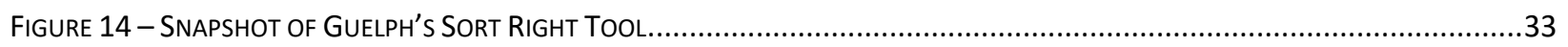

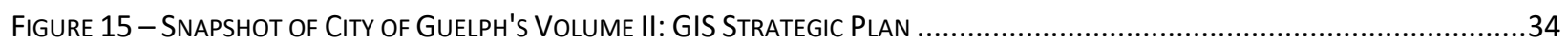

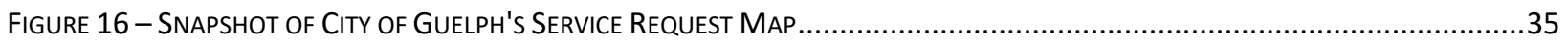

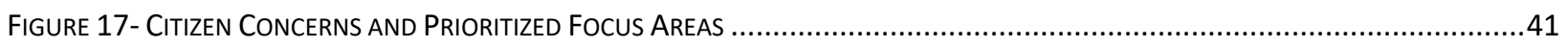

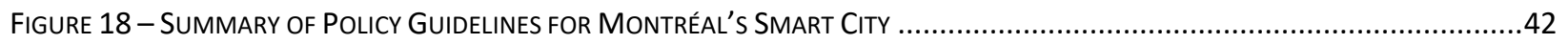

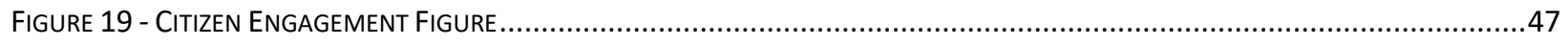

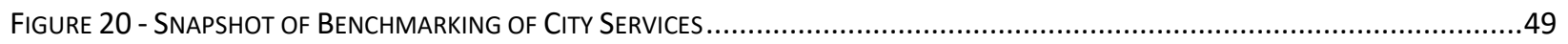

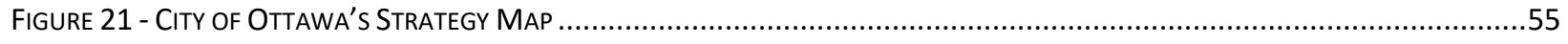

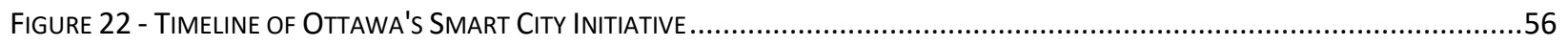

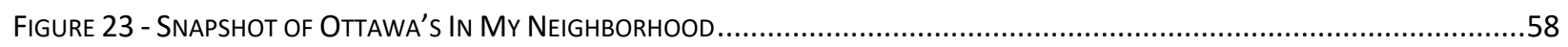

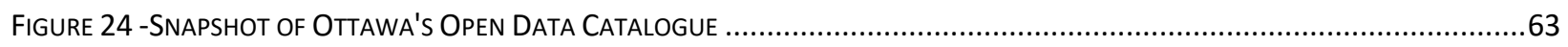

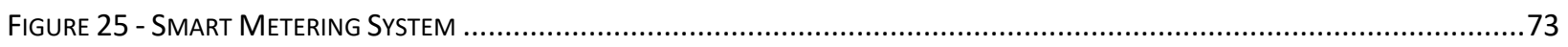

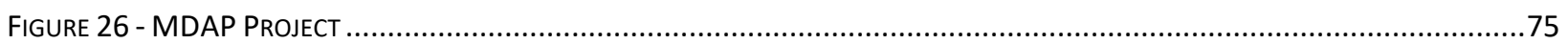

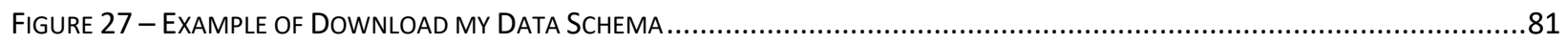

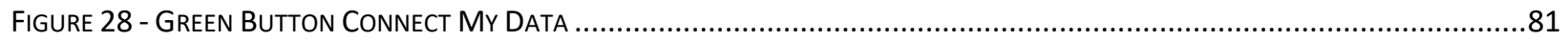

\section{List of Tables}

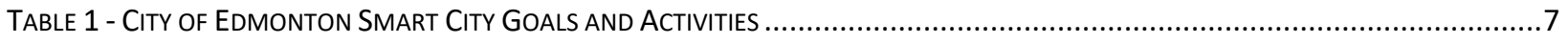

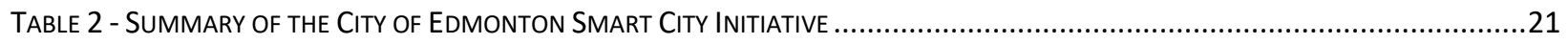

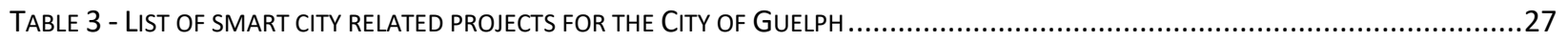

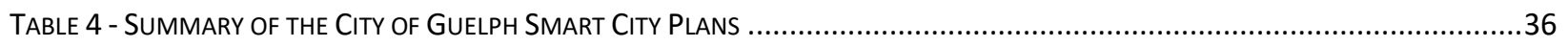

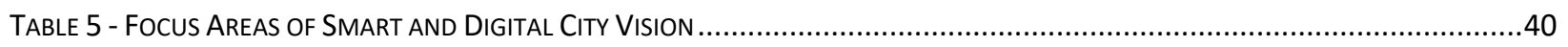

TABLE 6 - LIST OF SMART City Programs ANd EXAMPLES Of PROJECTS For LA VILLE DE MONTRÉAL ..........................................43

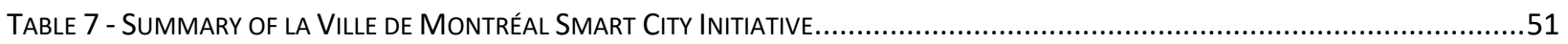

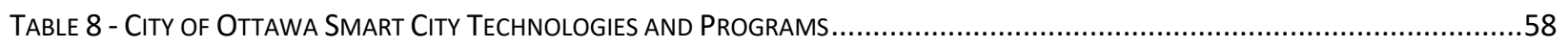

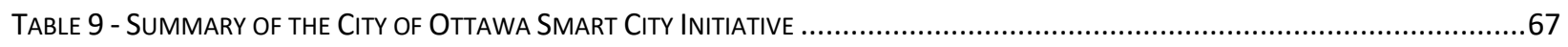

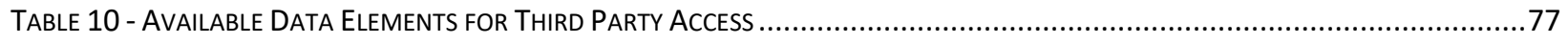

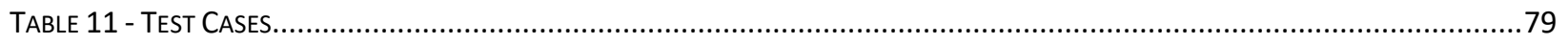

CC BY-NC-SA 4.0 


\section{About this Publication}

This report is an output of Open Smart Cities in Canada, a one-year collaborative research project led by OpenNorth and funded by Natural Resources Canada's GeoConnections program.

OpenNorth, founded in 2011, is Canada's leading not-for-profit organization specializing in open data and civic technology. We are an active member of a global community working in favor of inclusive and innovative ecosystems, improving government transparency and accountability, and increasing public participation in democracy towards enhanced citizen and community well-being. Guided by our core values and strong track record in applied research, we work to enhance data standards, shared governance models, and multi-stakeholder and multi-sectoral partnerships.

\section{Acknowledgements}

Open Smart Cities in Canada is a collaborative project. We would like to thank smart city representatives from the cities of Edmonton, Guelph, Montréal, and Ottawa and officials from the provinces of British Columbia and Ontario for sharing their time, expertise, and experiences with us. Furthermore, this project benefits from contributions made by the project's core team of experts and researchers. We are grateful to Professor Tracey P. Lauriault (Carleton University), David Fewer, LL.M., (Canadian Internet Policy and Public Interest Clinic (CIPPIC)), and Professor Mark Fox (University of Toronto) for providing their expert advice on the design of research and its outputs. Finally, we thank graduate students Stephen Letts and Carly Livingstone (Carleton University) for research assistance and editing over the course of the project.

Financial support is provided by GeoConnections, a national collaborative initiative led by Natural Resources Canada. GeoConnections supports the integration and use of the Canadian Geospatial Data Infrastructure (CGDI), an on-line resource that improves the sharing, access and use of open geospatial information.

\section{Additional Open Smart Cities in Canada Results}

See the links below for more Open Smart Cities in Canada outputs:

- Open Smart Cities in Canada: Executive Summary of Environmental Scan and Case Studies

- Open Smart Cities Guide

- Open Smart Cities FAQ

- Webinar 1

- Webinar 2

- Webinar 3 


\section{List of Acronyms}

ACE Analytics Center of Excellence (Edmonton)

AEC Advance Energy Centre

AMI Advanced Metering Infrastructure

API Application Programming Interface

BVIN Bureau de la Ville Intelligente et Numérique (Montréal)

CENGN Centre of Excellence in Next Generation Networking (Ottawa)

CFO Chief Financial Officer

CGMU Centre de gestion de la mobilité urbaine (Montréal)

CIO Chief Information Officer

CKAN Comprehensive Knowledge Archive Network

(Geo) CMS (Geographic) Content Management System

COTS Commercially Off the Shelf

CRM Citizen Relationship Manager (Guelph)

CSM Citizen Services Management

CVT Connected Vehicle Technology

DESS District Energy Sharing System

FEDC Finance and Economic Development Committee (Ottawa)

FOIP Freedom of Information and Protection of Privacy Act

GID Guelph Innovation District

GIS Geographic Information System

GPS Global Positioning System

IBM International Business Machines Corporation

ICF Intelligent Community Forum

ICT Information and Communications Technologies

IESO Independent Electricity System Operator (Ontario)

IoT Internet of Things

IP Intellectual Property

IT Information Technology

ITS Intelligent Transportation System 


\begin{tabular}{|c|c|}
\hline ISO & International Organization for Standardization \\
\hline KML & Keyhole Markup Language \\
\hline KPI & Key Performance Indicator \\
\hline LBS & Location Based Services \\
\hline LDC & Local Distribution Company \\
\hline LiDAR & Light Detection and Ranging \\
\hline MDAP & Meter Data Access Plan \\
\hline $\mathrm{MDM} / \mathrm{R}$ & Meter Data Management/Repository (Ontario) \\
\hline MUSH & Municipalities, Universities, Schools, and Hospitals \\
\hline NCR & National Capital Region \\
\hline OASIS & Organization for the Advancement of Structured Information Standards \\
\hline ODx & Open Data Exchange (Canada) \\
\hline OGC & Open Geospatial Consortium \\
\hline OEB & Ontario Energy Board \\
\hline PII & Personally Identifiable Information \\
\hline RFP & Request for Proposals \\
\hline RFT & Request for Tenders \\
\hline RIM & Records and Information Management \\
\hline SaaS & Software as a Service \\
\hline SIM & Spatial Information Management \\
\hline SME & Smart Metering Entity (Ontario) \\
\hline SMEs & Small and Medium Enterprises \\
\hline SPACE & Spatial Center of Excellence (Edmonton) \\
\hline $\mathrm{SPO}$ & Service de la Performance Organisationnelle (Montréal) \\
\hline SODA & Socrata Open Data API \\
\hline STM & Société de Transport de Montréal \\
\hline VGI & Volunteered Geographic Information \\
\hline
\end{tabular}




\section{Executive Summary}

The Assessment Report communicates the state of smart city initiatives of four cities in Canada, namely Edmonton, Guelph, Montréal, and Ottawa by reporting on how these cities are developing and rolling out their smart city plans. In addition, we include in our assessment inter-jurisdictional approaches related to smart cities by reporting on Ontario's governance of their Smart Grid. These results inform our objectives to (1) understand what smart cities mean in a Canadian context and (2) create open smart city guidelines intended for smart city leaders and decision makers.

An Open Smart City is where residents, civil society, academics, private sector, and public officials collaboratively mobilize data and technologies when warranted in an ethical, accountable and transparent way in order to govern the city as a fair, viable and liveable commons and balance economic development, social progress and environmental responsibility. Please see the Open Smart Cities Guide for more information about this definition.

To understand how each city defines, governs, and operationalizes their smart city, we conducted interviews with city officials and smart city environmental scans (E-Scans) at each city. Of the four cities, Edmonton, Montréal, and Ottawa currently have smart city strategies and the city of Montréal is during this research the only city to have published an action plan that includes impact evaluation indicators. Overall, all four cities deploy a range of smart city technologies and databased urbanism projects with relevant supportive strategic plans and programs.

\section{Why Smart City Strategies?}

Each city identified a unique set of reasons to pursue their smart city initiative, such as a combination of political campaign promises, internal re-organization and a vision promoted by political leadership, as well as external global economic pressures and trends towards the knowledge economy and high technology sector jobs.

\section{Smart City Resident Engagement?}

The extent to which the public was informed of smart city strategies varies by city. For instance, Montréal engaged residents directly to identify urban issues and suggest smart city projects as solutions; Edmonton incorporated citizen input indirectly by aligning their strategy's focus areas with their citizen informed municipal strategic plan, and Ottawa held invitation only consultations with stakeholders to solicit input on formulating focus areas for their smart city strategy. In addition, smart city strategies for these three cities were informed by research and in consultation with external experts and academics (e.g., best practices in other cities, participation in smart city networks or attending events, hiring private consultants, or examining international smart city standards and frameworks). Montréal is notable for referencing a multitude of European Union frameworks and case studies, some of which exemplify Open Smart City best practices.

There are many similarities in terms of focus. For instance, all four cities emphasize improving and innovating digital public services as a focus for their smart city initiative. Guelph's vision for a smart city emphasizes modernizing digital public services and fostering citizen-facing digital operations. In addition, all four cities either have, or plan to, reform technology procurement processes to encourage innovation, which includes the deployment of accelerator programs and public-private partnerships to pilot technologies with vendors. Montréal is notable for securing 
venture capital to support technology start-ups. In terms of smart city components, the City of Ottawa is unique in their development of a precision agricultural node along with a commitment to promote rural economic development as part of their smart city.

\section{Noteworthy Smart City Governance Structures?}

Cities have re-aligned governance structures to support smart city development. The City of Edmonton, for example, has a dedicated analytics unit, a Smart City Director, and an interdepartmental Smart City Steering Committee to assess risks and set strategic pathways. Guelph's plan includes the development of an IT Governance Committee with subcommittees dedicated to security and location security, digital practices, Geographic Information Systems (GIS), and innovation/service evolution. Both Edmonton and Guelph intend to include citizen representation on their governing committees.

\section{What of Open Smart Cities?}

The dedication of city staff's time and knowledge to the Open Smart Cities in Canada project demonstrates their willingness to advance smart cities that are open and transparent. Furthermore, the four cities included in this report display a commitment to their organization's open data programs. Open data programs are seen as a component of smart city strategies and open data is being praised in these strategies for its ability to unlock a wealth of innovation and to democratize access to public services and information.

What remains to be seen is whether current smart city objectives and guiding principles will align with open data programs, and open government frameworks and policies. Findings from this research suggest more can be done so that smart city programs actively work toward a vision that upholds values of openness, ethics, fairness, trustworthiness, and equity. Open Smart Cities require frameworks and business models that reward and encourage de-centralized, privacy enhancing and cyber-secure infrastructures, and their data ownership models ought to leverage properties of open standards, open source, and open data in order to disrupt proprietary data trends and technology lock-ins.

\section{Gaps?}

Currently, smart city programs lack:

1. Clearly communicated guiding principles for achieving smart city goals;

2. Procurement processes that uphold open principles and components (e.g., open data, open source, and open standards);

3. Privacy and security considerations and policies at the device level (e.g., meters and sensors);

4. Guidelines for Internet of Things (IoT) deployment related to transparency, privacy, and data management;

5. Consent models for sharing personally identifiable information (PII) with third parties;

6. Integration of civic technology actors in governance structures;

7. Mechanisms for sustained meaningful citizen engagement about smart city pathways and plans; and

8. Strategies to realize downstream benefits and risk of negative consequences.

These gaps are expected to be addressed in emerging future plans, and in some cases, it may be necessary to collaboratively rethink smart city plans with stakeholders, residents and municipal/community leaders. 


\section{Introduction}

Smart cities, intelligent cities, sustainable cities, sentient cities, cities as a platform, innovative cities, programmable cities, connected cities, and hackable cities are all labels used to describe new forms of data driven and networked urbanism. ${ }^{1}$ This form of urbanism often includes the following type of technologies: myriad of Internet of Things applications (IoT) (e.g., smart buildings, autonomous cars, etc.) especially with the use of sensors and meters, data dashboards, data portals, data visualization, data analytics, control rooms, WiFi, broadband, applications, software and platforms, any number of benchmarks and indicators, location-based services and GPS tracking, data (big and small), and GIS units. Technologies and techniques are deployed to measure, monitor, track, inventory, assess, and benchmark cities to better know and manage them. Smart cities may also be part of or synonymous with digital strategies, e-government, or municipal information technology (IT), as well as open data and open government. What is certain, is that definitions differ depending on who is doing the defining, be it a vendor, think tank, a consulting firm, standards body, researchers or civil society actors or an organization that develops readiness frameworks, indicator systems or that award smart city prizes. Finally, definitions, missions, visions, mandates, and principles associated with plans, strategies and roadmaps and implementations also differ from one 'smart city' to another.

The Open Smart Cities in Canada project therefore aims to better understand what smart cities are, and to assess whether or not they demonstrate openness in terms of data and information, algorithms, source code, standards, engagement, collaboration, leadership and governance. Specifically, the project examines: smart city strategies and initiatives, open and geospatial data and tools, standards, legalities, and information regarding the procurement of smart city technologies in order to:

1. contribute to the development of national policies, standards and mechanisms in relation to open municipal data, and support their implementation in ways that ensures the maintenance and updating of geospatial data and compatibility with global standards.

2. increase awareness of the tools, processes, and procedures, that produce open and geospatial data, and ways of actively determining the priority data that will become public and contribute to smart city initiatives.

The objective of this Assessment Report is to provide insight into the current practices of four cities in Canada, namely the cities of Edmonton, Guelph, Montréal, and Ottawa.

In addition, these four cities are governed by a complex set of multi-jurisdictional actors, regulation, laws, and entities that are unique to each jurisdiction and utility. In Canada, provinces and territories delegate powers to municipalities and have authority over vital public goods, such as health care, education, natural resources, and social welfare. In order to capture the complexity of inter-jurisdictional processes and coordination related to smart cities, we have additionally provided a case study about the governance and management of Ontario's electricity grid and

\footnotetext{
${ }^{1}$ Kitchin, Rob (2015) Data-driven, networked urbanism, Working Paper for the Data and The City workshop, NIRSA, Maynooth University, County Kildare, Ireland, http://www.spatialcomplexity.info/files/2015/08/SSRNid2641802.pdf
} 
smart meter data. The Ontario Smart Grid case study explains the complexity of utilities operations in Canada and a relationship between the province of Ontario and two case study cities, namely, the cities of Guelph and Ottawa.

\section{Overview of Methods}

First, an Environmental-Scan (E-Scan) of publicly available smart city documentation for the cities of Edmonton, Guelph, Montréal and Ottawa was conducted. The results of the E-Scan were then combined with expert knowledge provided by the Open Smart Cites in Canada team members to inform the creation of a semi-structured interview instrument. Initially, a structured survey was proposed, however, upon examination of the results of the E-Scan, it was discovered that each city was unique in terms of their smart city programs, and the approach was, therefore, shifted to speaking directly with experts in each city. In May and June of 2017, officials from the four collaborating cities generously provided approximately 90 minutes of their time to be interviewed over the phone or in person to discuss their city's smart city plans and strategies. All interviews were recorded and then transcribed. Finally, city officials responded to post-interview follow-up questions and validated a final draft of our assessment in the fall of 2017.

The following information was collected about each collaborating city: smart city visions and strategies; reasons for deploying smart city initiatives; perceived beneficiaries of the smart city; governance models (i.e. the mechanisms, relations, and approaches ${ }^{2}$ in place to direct the smart city); how smart city strategies have been deployed; citizen engagement about the smart city; definitions of "openness" and open characteristics, access to smart city data, and smart city business models; procurement of smart technologies; and perceived challenges and benefits of becoming a smart city. Each city assessment concludes with a summary of findings and key considerations for Open Smart Cities.

Finally, the Ontario case study is informed by a number of publicly available documents and information obtained from provincial public officials (i.e., Ministries of Energy, Municipal Affairs, Ministries of Economic Development and Research Innovation and Science (jointly), Transportation, Land Information Ontario, and the Treasury Board Secretariat). After broad research about Ontario's initiatives related to smart cities, we chose to focus on the interjurisdictional approach to the deployment of Ontario's smart grid and its related meters and thirdparty access to energy use data because of its wealth of information about how people, processes, and technology are coordinated to responsibly and ethically share and extract value from smart city datasets. Like we did with the cities, findings from the inter-jurisdictional case study were validated by representatives from the province of Ontario.

\footnotetext{
${ }^{2}$ European Commission. Analyzing the potential for wide scale roll out of integrated smart cities and communities solutions. June 2016. https://ec.europa.eu/energy/sites/ener/files/documents/d2 final_report_v3.0_no_annex_iv.pdf.
} 


\section{City Results}

The following provides an analysis of E-Scan results and information collected during the interview process with the four collaborating cities. Results for each city are structured as follows: smart city strategies, openness, geospatial data, procurement and a summary of observations.

\subsection{City of Edmonton}

The City of Edmonton, incorporated as a City in 1904, is the provincial capital for the province of Alberta and is one of Canada's major urban centres. The municipality administers a land area of 685.25 square kilometers that is situated in Treaty 6 territory and has a population of 932,546. ${ }^{3}$ The Edmonton region (census metropolitan area (CMA)) is an economic area of influence that includes a combination of municipal districts, cities, First Nations Reserves, villages, summer villages and towns, with a population of 1,321,426 and a large land area of 9,438.86 square

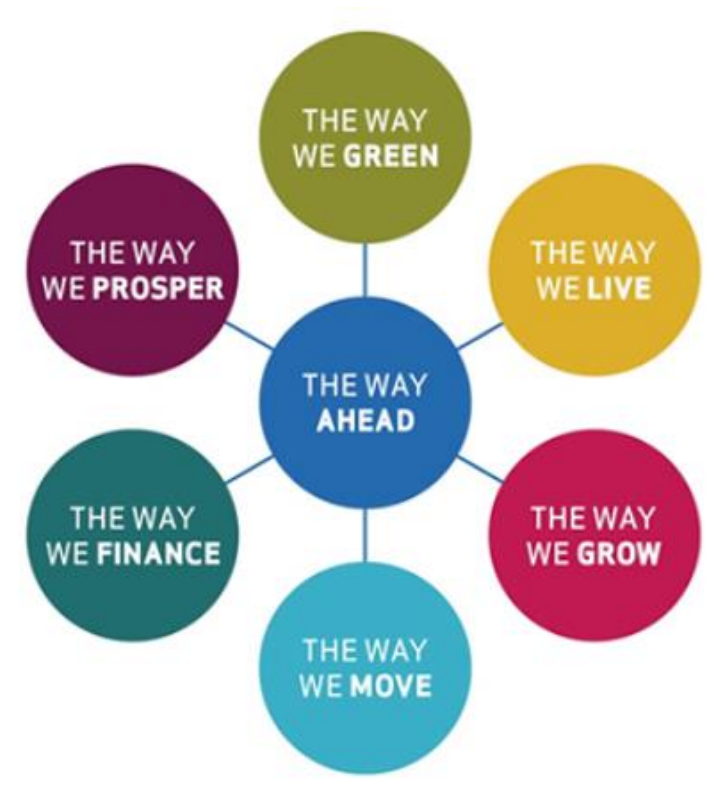

Figure 1 - Edmonton's Strategic Plan and Directional Plans (source: https://www.edmonton.ca/city_governme nt/city_vision_and_strategic_plan/theway-ahead.aspx)

\section{kilometers. ${ }^{4}$}

Edmonton is governed by 12 city ward councilors, a Mayor and a number of council committees ${ }^{5}$ as well a number of boards with appointed citizens, boards with other appointments and City Corporations, ${ }^{6}$ with 10,065 full-time employees (FTEs) and 2,027 part-time employees (PTEs). ${ }^{7}$

The city administration's strategic urban plan The Way Ahead sets, "10-year strategic goals to achieve the City Council's vision for Edmonton in 2040 and to direct long-term planning for the City of Edmonton". ${ }^{8}$ The plan cites four principles that underpin the development and implementation of the city's strategic plans: integration, sustainability, livability, and innovation. Six directional plans support municipal government in achieving the goals set forth by The Way Ahead (see Figure 1).

\footnotetext{
${ }^{3}$ Statistics Canada. 2017. Edmonton, CY [Census subdivision], Alberta and Division No. 11, CDR [Census division], Alberta (table). Census Profile. 2016 Census. Statistics Canada Catalogue no. 98-316-X2016001. Ottawa. Released August 2, 2017. http://www12.statcan.gc.ca/census-recensement/2016/dp$\mathrm{pd} /$ prof/index.cfm?Lang=E(accessed August 3, 2017).

${ }^{4}$ Statistics Canada. 2017. Focus on Geography Series, 2016 Census. Statistics Canada Catalogue no. 98-404X2016001. Ottawa, Ontario. Analytical products, 2016 Census http://www12.statcan.gc.ca/censusrecensement/2016/as-sa/fogs-spg/Facts-cma-eng.cfm?LANG=Eng\&GK=CMA\&GC=835

${ }^{5}$ City of Edmonton: Council and Committee Meetings - Current and ongoing City Council and Committee meeting schedules, agendas and minutes. https://www.edmonton.ca/city government/council-committee-meetings.aspx

${ }^{6}$ https://www.edmonton.ca/city_government/city_organization/list-of-agencies-boards-commissions.aspx

${ }^{7}$ http://content.eluta.ca/top-employer-city-of-edmonton\#

8 https://www.edmonton.ca/city_government/city_vision_and_strategic_plan/the-way-ahead-goals.aspx
} 
The region is home to the provincial government of Alberta, the University of Alberta, the Alberta Innovates - Technology Futures, large health care facilities and R\&D associated with the oil and gas industry, agriculture, forestry, and diamond mining. ${ }^{9}$ Edmonton's service and supply strengths traditionally centered on engineering and construction, manufacturing and metal fabrication and transportation and logistics. More recently however, the Edmonton Region has been able to capitalize on opportunities in emerging industries related to the energy sector including water and waste water treatment, remediation technologies, waste management, information and communication technologies and financial services". ${ }^{10}$

\subsubsection{Strategy}

The City of Edmonton released their Smart City Strategy in the summer of 2017. ${ }^{11}$ The creation of the strategy was inspired by an internal reorganization process in government and a new vision from political leaders. It aligns with the city's overall long term strategic plan and vision, The Way Ahead (updated in 2014). ${ }^{12}$ Furthermore, smart city officials at Edmonton studied international smart city initiatives to inform the development of the Smart City Strategy.

Edmonton's smart city initiatives that predated the strategy locally evolved. As a result, the Smart City Strategy echoes early smart city efforts and implementations, while also providing a future vision and goals for Edmonton's smart city. The strategy will be accompanied by the release of a smart city roadmap ${ }^{13}$ to direct Edmonton's pilot projects and develop a plan for the smart city that is flexible and agile. The roll out of the smart city is emphasized as collaborative and is envisioned as a partnership between Industry, Community, Government, and Academia (see Figure 2).

\footnotetext{
${ }^{9}$ Historica Canada (2017) The City of Edmonton, The Canadian Encyclopedia, accessed August 3, 2017 http://www.thecanadianencyclopedia.ca/en/article/edmonton/

${ }^{10}$ City of Edmonton (2012) Technical Report: Economic + Industry Analysis "The Way We Prosper" An Economic Development Plan prepared by Millier Dickinson Blais for the City of Edmonton Economic Development Plan Technical Report, https://www.edmonton.ca/city_government/documents/PDF/TWWP Technical_Report.pdf.

${ }^{11}$ https://www.edmonton.ca/city_government/documents/PDF/Smart_City_Strategy.pdf

12 https://www.edmonton.ca/city_government/documents/The Way_Ahead_(Final-Web).pdf

${ }_{13}$ Open City and Technology at the City of Edmonton. Interview with Rachel Bloom. Personal Interview. May $23^{\text {rd }}$, 2017.
} 

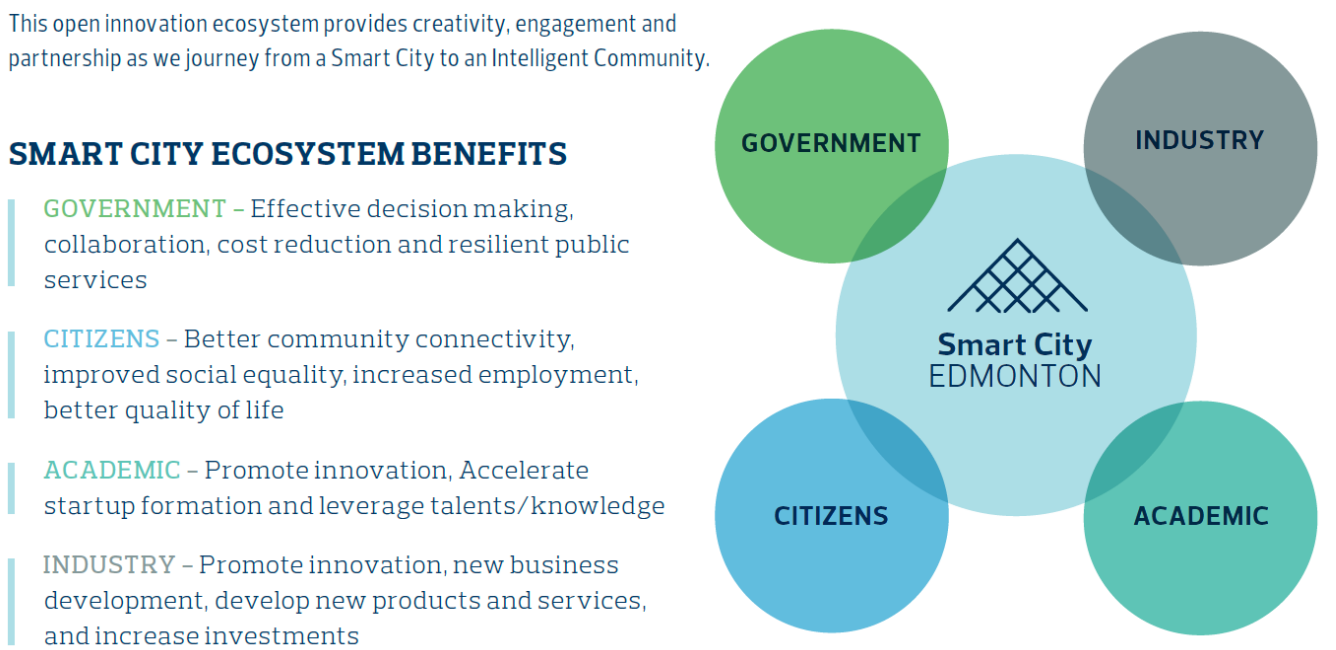

\section{Figure 2 - City of Edmonton Smart City Ecosystem Benefits, (Source: Smart City Strategy (2017) p. 7)}

For Edmonton, a smart city is "about creating and nurturing a resilient, livable, and workable city through the use of technology, data and social innovation". ${ }^{14}$ Resilient, livable and workable in the strategy refer to the characteristics of a "connected", "well-planned", and "flexible" city that has citizens who are healthy and more engaged with their community and focused on reducing the city's environmental footprint. Technology and social innovation are considered by the city to be the backbone to achieving Edmonton's smart city vision and goals. ${ }^{15}$

Subsequently, Edmonton's strategy includes the following goals: (1) resiliency; (2) livability; and (3) workability (see Figure 3). See Appendix A for more information about initiatives in Edmonton that support achieving these goals. According to the strategy, a resilient municipality can withstand external shocks such as economic crises, epidemics, congestion, transport breakdowns, and environmental pollution. ${ }^{16}$ Specific areas of focus of Edmonton's smart city are as follows:

1. open city;

2. citizen engagement;

3. economic diversification;

4. mobility;

5. infrastructure;

6. education;

7. community;

8. health; and

9. the environment

\footnotetext{
14“Smart City Strategy 2017". City of Edmonton. Last Modified in 2017. https://www.edmonton.ca/city government/documents/PDF/Smart_City_Strategy.pdf. ${ }^{15}$ Open City and Technology at the City of Edmonton. Interview with Rachel Bloom. Personal Interview. May $23^{\text {rd }}$, 2017.

16 "Smart City Strategy 2017". City of Edmonton. Last Modified in 2017. https://www.edmonton.ca/city_government/documents/PDF/Smart_City_Strategy.pdf.
} 
The city has not yet developed indicators and standards by which to implement, measure and benchmark smart city targets. However, it has developed progress indicators to assess their open city plans, as outlined in Edmonton's Open City 2017 Refresh report that includes open engagement, open data, open information, and open analytics. ${ }^{17}$ Open city is a focus of the resiliency goal articulated in the city's Smart City Strategy (see Figure 3).

In terms of the Smart City Strategy, the city has not yet defined how data, smart city technologies and new governance structures will be applied to make the city more resilient, and if fundamental policies and practices will be modeled with data. Additionally, questions remain about whether new directions will be data and model driven, or citizen led. Operational efficiency, health, economic diversification, and social inclusion are the foci of Edmonton's smart city and these align with City Council priorities. ${ }^{18}$ Specific processes and practices on how to achieve these goals are, however, are not yet available. The forthcoming roadmap is expected to provide more operational details related to Edmonton's Smart City Strategy.

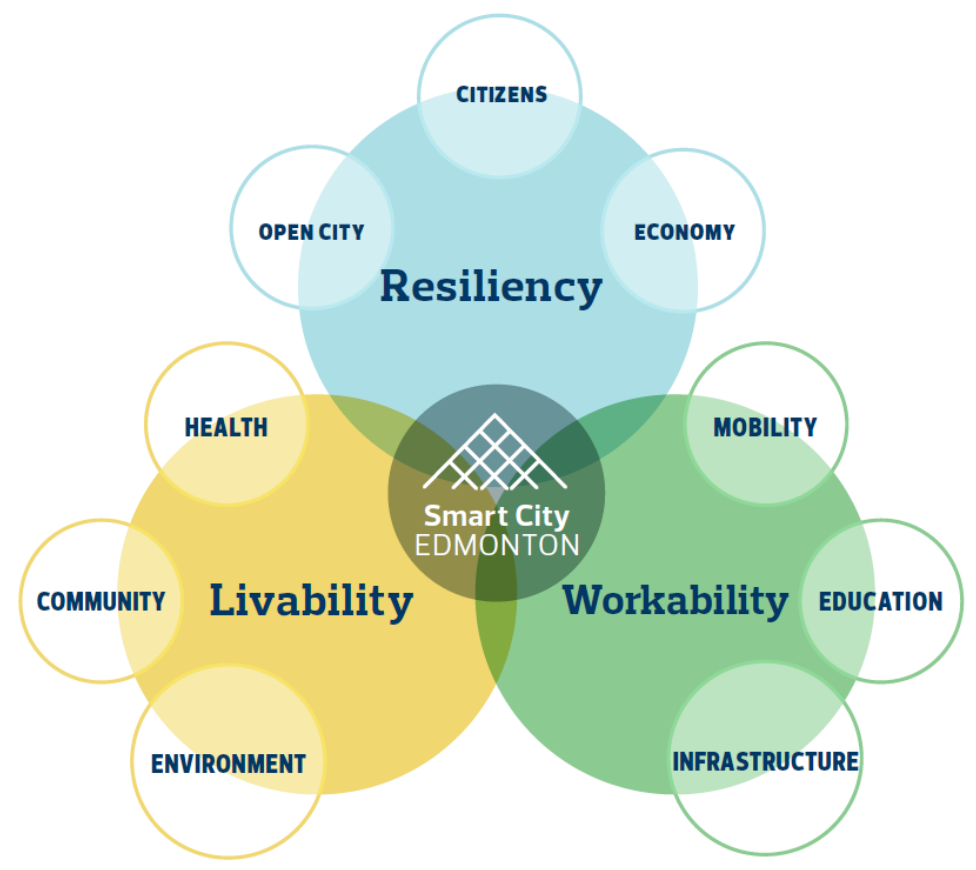

GOAL ONE

Resiliency

A municipality that is resilient is adaptive, wellplanned and flexible - one that can withstand external shocks such as economic crisies, epidemics, congestions, transport breakdowns, and environmental pollutions.

GOAL TWO

Livability

A municipality that is livable is one in which citizens are healthy, engaged with their community and actively minimize their environmental footprint.

\section{GOAL THREE}

Workability

A municipality that is workable is one that connects its citizens through advanced transportation and mobility, broadband connectivity, educational institutions and smart infrastructure.

Figure 3 - City of Edmonton Smart City Goals (Source: Smart City Strategy (2017) p. 9)

\subsubsection{Perceived Beneficiaries}

Citizens are considered by smart city representative to be the primary beneficiaries of Edmonton's smart city and were engaged in The Way Ahead report, which strategically informed the Smart City Strategy. Perceived benefits to citizens cited in the document include economic development, efficient and effective programs and services, and advancing Edmonton's Open City Philosophy.

\footnotetext{
17 "Open City Initiative 2017 Refresh". City of Edmonton. Open City. March 2017. https://www.edmonton.ca/city government/documents/Open_City_Initiative.pdf ${ }_{18}$ Open City and Technology at the City of Edmonton. Interview with Rachel Bloom. Personal Interview. May 23 $3^{\text {rd }}$ 2017.
} 
A marketing/communications strategy will also be developed to inform citizens about smart city plans and benefits of the Strategy. Public communications are deployed via its Open Data Twitter account (@OpenDataEdm) and website.

Some groups are identified as being targeted beneficiaries for specific projects. For example, a project to crowdsource and map accessibility to buildings around Edmonton is intended to benefit people with disabilities. Edmonton plans to use these crowdsourced data to inform municipal infrastructure and facility maintenance. ${ }^{19}$ The extent to which these data will inform accessibility policy and actions for the future is uncertain.

\subsubsection{Smart City Components}

There are a number of ongoing activities that predate the Strategy but are nonetheless part of Edmonton's smart city. These are as follows: (1) intelligent transportation systems; (2) data-based traffic management systems; (3) open data; (4) data analytics; (5) the Internet of Things (IoT) (e.g., 311 app, connected rain gauges, GPS enabled transit buses, traffic lights, traffic monitors, realtime dashboard data streams, etc.); (6) renewable resource management; (7) waste management; (8) geo-demographics (Environics, InfoCanada, StatsCanada, etc.); (9) smart fare for transit; and (10) a smart bus system. According to the smart city representatives at the city, IoT deployment refers to sensors and data collection tools throughout the physical landscape that stream data into various databases and are then integrated when needed for real-time dashboarding, analysis, or decision making. Table 1 includes smart city activities identified by the E-scan and relates them to goals and initiatives in Edmonton's Smart City Strategy.

Table 1 - City of Edmonton Smart City Goals and Activities

\begin{tabular}{|c|c|c|}
\hline $\begin{array}{l}\text { City of Edmonton } \\
\text { Activities }\end{array}$ & Smart City Descriptors & $\begin{array}{c}\text { City of Edmonton Smart City } \\
\text { Goals }\end{array}$ \\
\hline Edmonton Open Data Portal & $\begin{array}{l}\text { City dashboard, city performance } \\
\text { indicators, civic engagement, open } \\
\text { data, geo-visualizations, data } \\
\text { visualizations, open analytics, open } \\
\text { data awards, open government } \\
\text { policy }\end{array}$ & \multirow[t]{2}{*}{ Resiliency / Open City } \\
\hline$\frac{\text { Analytics Centre of }}{\text { Excellence }(\mathrm{ACE})}$ & $\begin{array}{l}\text { Predictive modeling, GIS, location } \\
\text { allocation analysis, quality of life } \\
\text { indicators, predictive policing } \\
\text { algorithms, mining algorithms, } \\
\text { open data analytics, geo- } \\
\text { demographics, open science }\end{array}$ & \\
\hline
\end{tabular}

\footnotetext{
${ }^{19}$ Open City and Technology at the City of Edmonton. Interview with Rachel Bloom. Personal Interview. May $23^{\text {th }}$,
} 2017. 


\begin{tabular}{|c|c|c|c|}
\hline Open City Policy & $\begin{array}{l}\text { Open government policy, open } \\
\text { data, civic engagement }\end{array}$ & & \\
\hline Citizen Dashboard & $\begin{array}{l}\text { Performance metrics, digital public } \\
\text { services, open data, geo- } \\
\text { demographics }\end{array}$ & & \\
\hline $\begin{array}{l}\frac{\underline{\text { Apps4Edmonton and }}}{\text { Annual Open Data Hack-a- }} \\
\underline{\text { thons }}\end{array}$ & $\begin{array}{l}\text { Hack-a-thon, open data, smart city } \\
\text { events }\end{array}$ & \multicolumn{2}{|c|}{$\begin{array}{l}\text { Resiliency / Citizens \& Open } \\
\text { City / Engagement \& Open Data }\end{array}$} \\
\hline$\frac{\text { Alberta Smart City Alliance }}{\text { membership }}$ & $\begin{array}{l}\text { Smart city alliance, smart city } \\
\text { research }\end{array}$ & \multicolumn{2}{|c|}{ Resiliency / Economy } \\
\hline$\frac{\text { Enerkem biorefineries }}{\text { system }}$ & $\begin{array}{l}\text { Waste management, renewable } \\
\text { resources, smart energy }\end{array}$ & \multirow{2}{*}{\multicolumn{2}{|c|}{ Livability / Environment }} \\
\hline $\begin{array}{l}\text { District Energy Sharing } \\
\text { System (DESS) }\end{array}$ & $\begin{array}{c}\text { Energy sharing and distribution } \\
\text { systems, renewable resources, } \\
\text { energy efficiency, part of a } \\
\text { Carbon-neutral Blatchford }{ }^{20} \\
\text { community }\end{array}$ & & \\
\hline Data-Based Crime Fighting & $\begin{array}{c}\text { Safe City, indicators and } \\
\text { benchmarks, Key Performance } \\
\text { Indicator (KPI), geo-demographics }\end{array}$ & Resiliency & Livability \\
\hline$\frac{\text { ACTIVE-AURORA test-bed }}{\frac{\text { for wireless Connected }}{\text { Vehicle Technology }}}$ & $\begin{array}{l}\text { Intelligent transportation Systems } \\
\text { (ITS), Connected Vehicle } \\
\text { Technology (CVT), IoT, standards, } \\
\text { smart mobility }\end{array}$ & \multirow{3}{*}{\multicolumn{2}{|c|}{ Workability / Mobility }} \\
\hline $\begin{array}{l}\text { IBM Smarter Cities } \\
\text { Challenge award to fund } \\
\frac{\text { traffic management }}{\text { modeling System }}\end{array}$ & $\begin{array}{l}\text { Predictive data analytics, } \\
\text { Volunteered Geographic } \\
\text { Information (VGI), citizen } \\
\text { engagement, open data, and } \\
\text { performance indicators, smart } \\
\text { mobility, standards, IoT }{ }^{21}\end{array}$ & & \\
\hline$\underline{\text { Smart Bus Pilot Project }}$ & $\begin{array}{c}\text { Digital public services, data-based } \\
\text { transit service management, smart } \\
\text { mobility, Location Based Service } \\
\text { (LBS) }\end{array}$ & & \\
\hline
\end{tabular}

\footnotetext{
${ }^{20} \mathrm{https}$ ://www.edmonton.ca/projects_plans/blatchford.aspx

21 "City of Edmonton Response to IBM Smarter Cities Report". City of Edmonton. Accessed August 2017. https://www.edmonton.ca/transportation/PDF/IBM_SmarterCities_NextSteps.pdf.
} 
$\underline{\text { Smart Fare System }}$

ITS, digital transit services, smart mobility

\subsubsection{Smart Mobility}

Edmonton received International Business Machines Corporation's (IBM) Smarter City Challenge award for reducing traffic congestion and increasing safety. The award fostered a partnership between IBM and Edmonton's Office of Traffic Safety to pilot software and analytics to predict traffic patterns. ${ }^{22}$ IBM also provides recommendations to improve traffic safety via integrating various data sets across static, real-time and dynamic data sources with the use of sensors, meters and software. ${ }^{23}$

The City of Edmonton is an active partner with the University of Alberta in traffic management modeling and Connected Vehicle Technology (CVT). The ACTIVE-AURORA project ${ }^{24}$ is a partnership between University of Alberta and University of British Columbia and utilizes connected vehicles with wireless mobile devices to exchange information in real-time with roadside equipment (i.e. traffic lights and message signs) and other vehicles. ${ }^{25}$ The project tests standards for smart vehicle technology at the ACTIVE Test-Bed in Edmonton so that traffic information and road construction information from in-vehicle GPS and transportation systems can be automatically communicated. ${ }^{26}$ The project aims to improve traffic safety with pedestrian alerts; notifications of unsafe speed approaching a curve; warnings for following a vehicle too closely; notifications of high-collision locations; notifications of recommended driving speed for different traffic conditions; and notifications of whether a vehicle can safely pass through a green light before it turns red. ${ }^{27}$ The CVT pilot provides geospatial-based traffic solutions through volunteered geographic information (VGI) updates from mobile-based social media platforms such as Twitter.

In addition, the business units purchase VGI from TomTom and in the past, considered collecting VGI from Uber Movement, ${ }^{28}$ Strava,${ }^{29}$ and others. City staff use Miovision's proprietary traffic monitoring technology services to collect geo-enabled traffic movement data. ${ }^{30}$

\footnotetext{
$22 \mathrm{http} / / / \mathrm{www}$. gov.edmonton.ab.ca/transportation/traffic safety/ibm-smarter-cities-recommendations.aspx

${ }^{23} \mathrm{http} / / / \mathrm{prd}$-ibm-smarter-cities-challenge.s3.amazonaws.com/applications/edmonton-canada-full-report-2011.pdf

${ }^{24}$ https://www.alberta.ca/release.cfm?xID=4342706B2F973-F636-E821-D94C9596D4DB4460

${ }^{25}$ http://globalnews.ca/news/3383637/signs-crop-up-in-west-edmonton-heralding-project-that-sees-wirelesstechnology-talk-to-cars/

${ }^{26} \mathrm{http}: / /$ news.gc.ca/web/article-en.do?nid=1125659: "On the Front Edge of Smart Vehicle Technology". Accessed on March 6, 2017. https://www.edmonton.ca/city_government/initiatives_innovation/smart-vehicle-technology.aspx.

${ }^{27} \mathrm{http}$ ://globalnews.ca/news/3383637/signs-crop-up-in-west-edmonton-heralding-project-that-sees-wirelesstechnology-talk-to-cars/

${ }^{28} \mathrm{https://movement.uber} \cdot \mathrm{com} / \mathrm{cities}$ ?lang=en-CA

${ }^{29} \mathrm{http} / / /$ metro.strava.com/

30 https://transformingedmonton.ca/eyes-on-intersections-doing-more-with-less-for-better-traffic-flow/
} 
Edmonton is planning to implement a smart transportation system that includes a smart fare system $^{31}$ for public transit and a smart bus pilot project. ${ }^{32}$ The smart fare system is a "tap and go" and account-based fare payment system for Edmonton's public transit. It is designed to make paying for transit more stream-lined and credit-based. The smart fare system, which will be fully implemented by the City in 2020, will be interconnected with the smart bus pilot project, a platform for delivering real-time geographic information about transit services on the web and mobile applications. This is part of Edmonton's Transit Strategy ${ }^{33}$ that included public engagement, was informed by advanced analytics, and addressed concerns related to accessibility and affordability.

\subsubsection{Smart Energy}

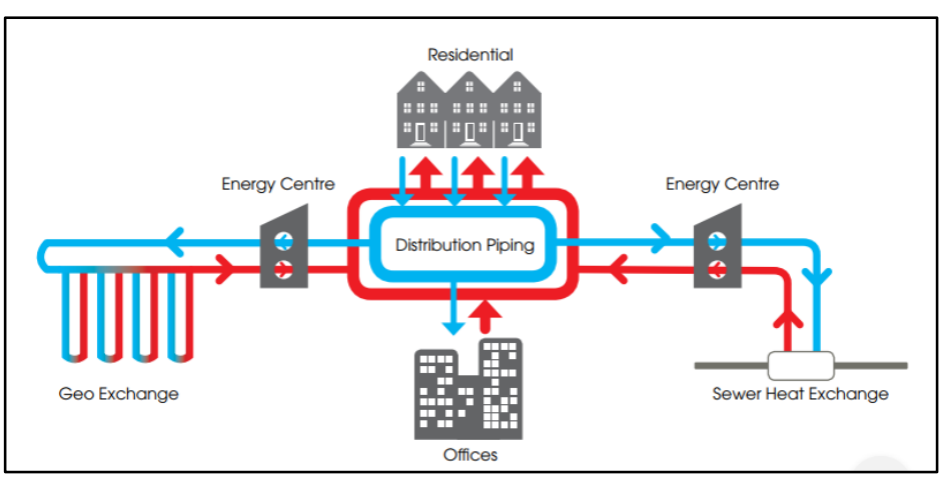

Figure 4 - Diagram of DESS for Blatchford development (source:

https://www.edmonton.ca/city_government/docu ments/Blatchford_booklet_DESS_overview_final Sept_2015.pdf)

photovoltaic panels. ${ }^{36}$ Canadian experts in green energy designed the system and Edmonton City Council designated 19.4 million CAD to fund the initial stage of DESS and approved the project

${ }^{31}$ City of Edmonton. Transportation Committee. Smart Fare Project. Edmonton, AB: City Council Minutes, 2014. Accessed March 13, 2017.

http://sirepub.edmonton.ca/sirepub/cache/2/vapuhcm2eozv0a4u0zhbpxub/37818003132017023139303.PDF.

${ }^{32}$ City of Edmonton. Transportation Committee. Smart Fare Project. Edmonton, AB: City Council Minutes, 2014. Accessed March 13, 2017.

http://sirepub.edmonton.ca/sirepub/cache/2/vapuhcm2eozv0a4u0zhbpxub/37818003132017023139303.PDF.

33 https://www.edmonton.ca/transportation/transit-strategy.aspx

34 "Blatchford: Implementing the Vision: District Energy". Accessed March 13, 2017, https://www.edmonton.ca/city_government/documents/Blatchford_booklet_DESS_overview_final_Sept_2015.pdf.

35 Stolte, Elise, "'So it's not science fiction?': Private Sector ready to bid on turning the sewage into heat at Blatchford development." Edmonton Journal. Last modified July 7, 2016, http://edmontonjournal.com/business/energy/so-its-not-science-fiction-private-sector-ready-to-bid-on-turningsewage-into-heat-at-blatchford-development.

36 "Blatchford: Implementing the Vision: District Energy," accessed March 13, 2017, https://www.edmonton.ca/city_government/documents/Blatchford_booklet_DESS_overview_final_Sept_2015.pdf. 


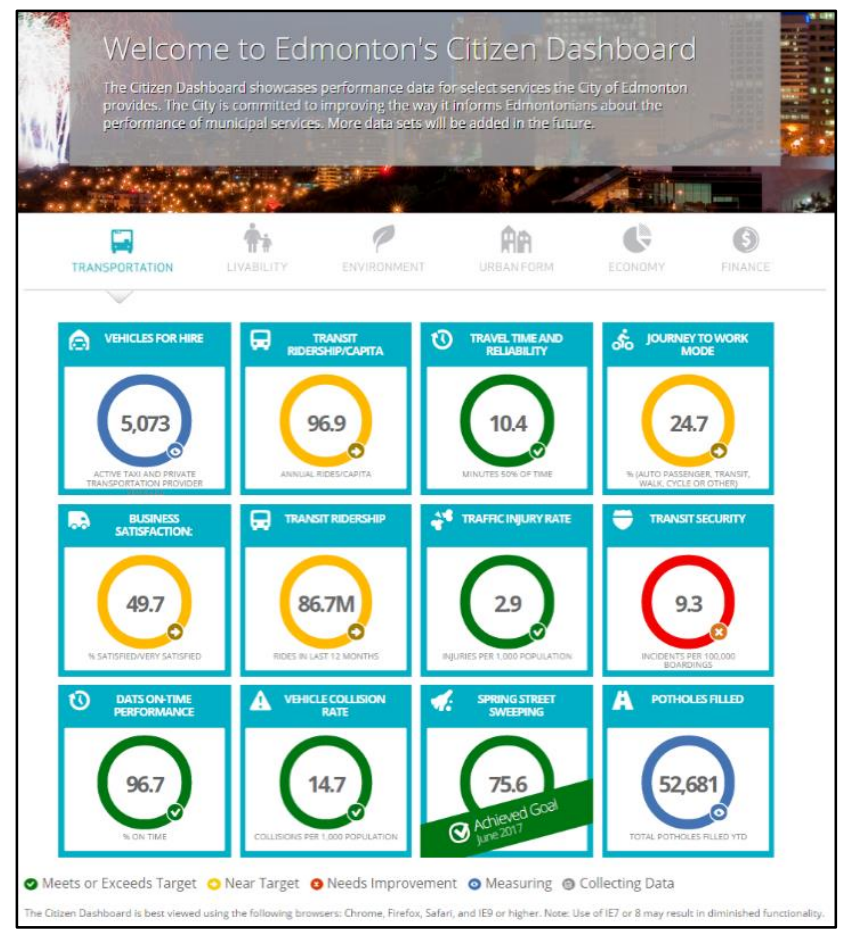

Figure 5 - Snapshot of Edmonton's Citizen Dashboard (source: https://dashboard.edmonton.ca/)

on December 8, 2016. ${ }^{37}$ Proponents of DESS envision that it will efficiently generate and distribute energy and reduce the municipality's ecological footprint.

Finally, the Edmonton's municipal government is engaged in a unique partnership with Enerkem, ${ }^{38}$ a biofuel company based in Edmonton that has developed a system to transfer waste into renewable resources. Edmonton's government has invested 10 million in equipment for Enerkem's waste-tobiofuel facility. ${ }^{39}$

\subsubsection{Data based Indicators and Analytics}

The City of Edmonton utilizes data for internal decision-making via the Analytics Centre of Excellence (ACE). Part of ACE's mandate is to act as an internal consultation service to city staff and support experts to develop innovative data-based solutions to address a variety of issues. Examples of ACE projects include the analysis of crime hotspots in collaboration with the Chief Analytics Officer and End Poverty Edmonton and other non-profit organizations in the city, ${ }^{40}$ as well as geospatial City services demand modeling, and an analysis of poverty in Edmonton. ${ }^{41}$ ACE utilizes geodemographics and collaborates closely with the University of Alberta Computer Science and Alberta Machine Intelligence Institute staff and students. The Open Science initiative also demonstrates a unique kind of collaboration between academia and local government in this field. ${ }^{42}$

The City of Edmonton uses open and administrative data to measure and benchmark the performance of City services. Edmonton's Citizen Dashboard uses open data to visualize service information online and compare the current performance of departments with target performance

37 "City Council Approves District Energy Sharing System for Blatchford," Blatchford (blog), last modified on December 12, 2016, http://blatchfordedmonton.ca/city-council-approves-district-energy-sharing-system-forblatchford/.

${ }^{38}$ Lynch, David. Enerkem biorefineries: A Smart City Solution for Waste conversion to Fuels and Chemicals. PowerPoint presentation. Last modified March 2016. www.acamp.ca/wp-content/uploads/2016/03/18-DavidLynch.pptx.

${ }^{39}$ https://globalnews.ca/news/3517219/edmonton-looking-at-whole-new-garbage-collection-system/

40 https://www.edmonton.ca/residential_neighbourhoods/fire_safety/neighbourhood-empowerment-team.aspx

41 "Analytics," Edmonton (blog), accessed March 13, 2017, https://www.edmonton.ca/city_government/initiatives_innovation/analytics.aspx.

42 http://ace.edmonton.ca/outreach/open-science/h 
metrics (see Figure 5). ${ }^{43}$ This dashboard categorizes metrics by transportation, livability, environment, urban form, economy, and finance.

\subsubsection{Smart City Networks and Awards}

In addition to these projects, the City of Edmonton is a member of the Alberta Smart City Alliance and was a recipient of Intelligent Community Forum's (ICF) title of Top7 in 2017, as well as Smart21 in 2008, 2009, 2015, and 2017 for their smart city initiatives. Edmonton contributes to the Alberta Smart City Alliance via knowledge creation, identifying opportunities, and piloting smart city projects, which are then profiled and shared among Alliance members. Finally, the city hosts an annual Open Data Day Hackathon (started in 2014) to promote the development of applications that use open data. The City recently convened and hosted the Canadian Open Data Summit 2017.

\subsubsection{Governance}

Edmonton has formulated a governance structure for the smart city that has a dedicated analytics unit, a Director, and a Steering Committee (see Figure 6). The Smart City Steering Committee is the governing body and executive sponsor of Edmonton's Smart City Strategy and makes decisions regarding risk assessment practices and strategic pathways. The Smart City Steering Committee consists of Branch Managers that are applicable to the Strategy, but smart city representatives are also looking into including citizen representation. The Smart City Director is responsible for the operations of the Smart City plans and reports to the Open City and Technology Branch Manager, which is part of the department of Financial and Corporate Services led by the Chief Financial Officer (CFO). The former Open and Innovation Branch merged with Information Technology Branch to create the Open City and Technology branch. Directors and Branch Managers of the City's climate strategy, transit, citizen engagement, and economic development are linked laterally to the Smart City team. The City's Chief Information Officer (CIO) sits on the Smart City Steering Committee.

The city's open data team is an operational unit within the smart city organizational structure. Open data, open city, and smart city strategies are the responsibility of the Smart City Director. The municipal Corporate Access and Privacy Manager works for the City Clerk's Office and their primary responsibility on open data matters is to advise on adherence to privacy legislation. ${ }^{44}$ The Smart City Director also chairs an Open Data Advisory Group which is an internal entity comprised of data stewards and legal advisors within city government. This advisory group identifies new opportunities for open data releases, builds a culture of open data, and identifies perceived privacy risks. The city recently has created an Open Data Citizen Advisory Committee that includes external members such as open data users and advocates.

Privacy impact assessments are encoded into the city's Information Communications Technologies (ICT) that collects data and all City technology goes through a privacy impact

\footnotetext{
43 "Edmonton's Open Data Portal," accessed March 14, 2017, 2017. https://data.edmonton.ca/.

44 Open City and Technology at the City of Edmonton. Interview with Rachel Bloom. Personal Interview. May $23^{\text {rd }}$, 2017.
} 
assessment as per FOIP guidelines. The city's Enterprise Architecture Group in the IT branch performs security and risk assessment on all technology.

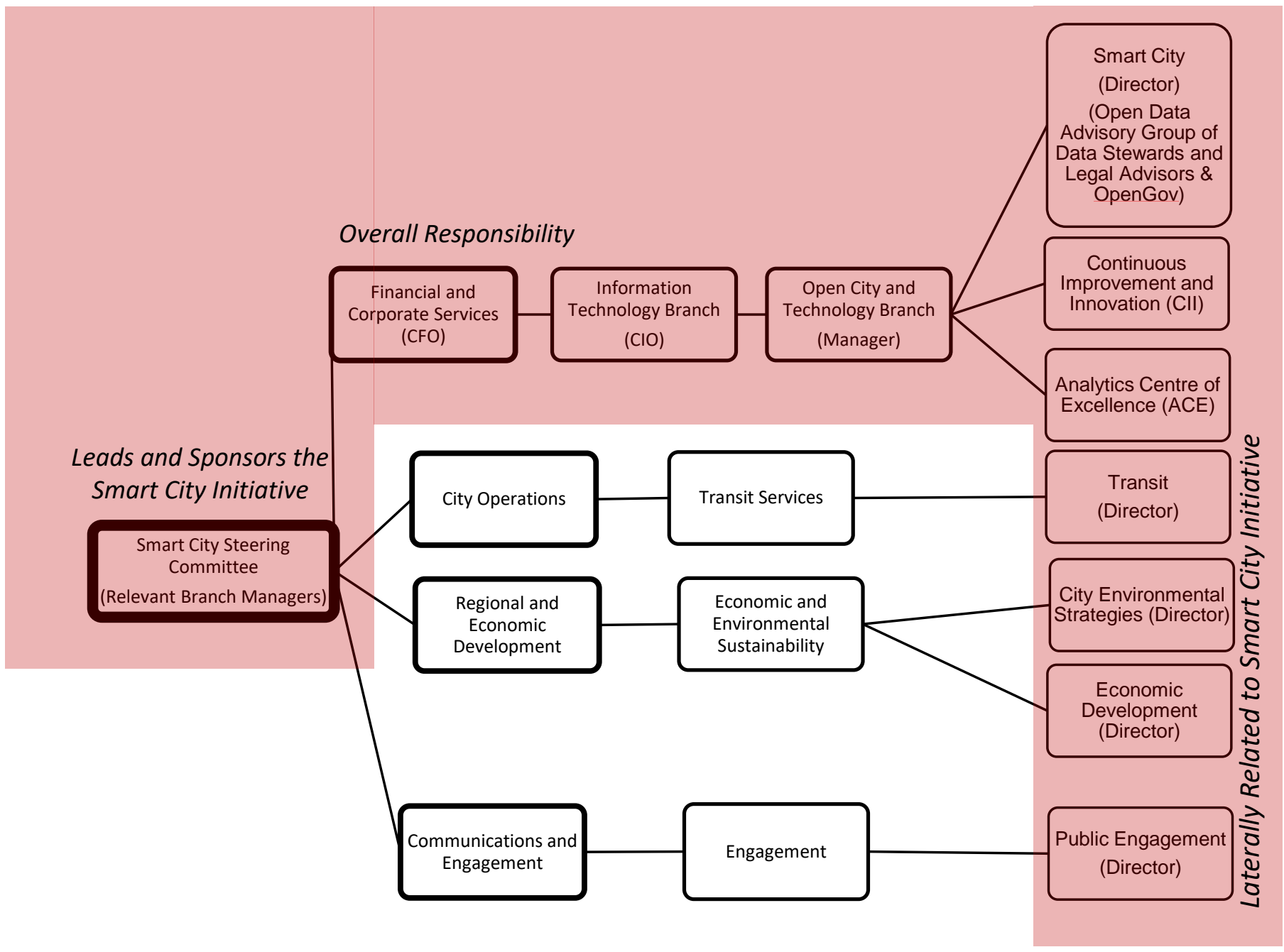

Figure 6 - City of Edmonton Smart City Governance Structure

\subsubsection{Procurement}

The City of Edmonton is considering making changes to their procurement process to support their smart city plans. The new approach may include implementing pilot projects for smart city technologies to test them before they are fully deployed more broadly throughout the city. 
Standards will be taken into consideration when procuring Smart City technologies, although the city has not yet made decisions about whether to adopt or reject standards for smart city technologies. Purchasing bylaws are not considered an impediment for the acquisition of smart city technologies and the smart city initiatives in the strategy do not have a centralized budget.

\subsubsection{Openness}

The Smart City Strategy cites the Edmonton's open city as a focus area for its goal of becoming a resilient city. ${ }^{45}$ Resiliency in this context is related data literacy and informed public debate.

Edmonton's Open City Initiative (2014) is a municipal perspective on the philosophy of open government. The initiative defines an open city as one that is responsive to the goals and objectives of an informed and engaged public; it reduces barriers to information and provides access to services through digital networks and has the ability to connect people wherever they are. ${ }^{46}$ In 2017, the city refreshed its official Open City Initiative. This updated Open City Initiative includes the following goals: Open City Foundation, Open Engagement, Open Data, Open Information, and Open Analytics. ${ }^{46}$ These goals are accompanied with a set of progress indicators and actions.

The Open City Initiative in 2014 guided the development of the Open City Policy adopted by City Council in 2015.47 This Policy articulates the city's commitment to promote principles of transparency, participation, collaboration, inclusiveness, and innovation. ${ }^{48}$ The Policy's framework emphasizes the use of data for evidence-based decision-making and an open data-bydefault approach to data provision. In addition, it emphasizes providing platforms to increase citizen interactions with their government and leveraging technology to improve programs and services provided to residents. It states that the city remains committed to working with academic, public and private partners outside of government to advance Open City principles.

Data captured by smart city technologies falls under the city's open by default principle specified in their Open City Policy framework: "the City should ensure information and data are open by default and private where appropriate". ${ }^{49}$ However, it is not yet clear how the smart city will ensure it upholds the principles laid out in its Open City Policy via procurement processes and contract negotiations.

There are a number of ongoing open city projects in Edmonton, such as the Open Data Portal, Open Data Strategy, the Citizen Dashboard, ACE, and the Metro Open Data Group. ${ }^{23}$ Some of these initiatives are described in more detail below.

\footnotetext{
${ }^{45}$ Smart City Strategy (2017). City of Edmonton. Last Modified in 2017.

https://www.edmonton.ca/city_government/documents/PDF/Smart_City_Strategy.pdf.

${ }^{46}$ https://www.edmonton.ca/city_government/documents/Open_City_Initiative.pdf

47 "Open City Policy," Corporate Service Department. Edmonton, AB. 2015. Accessed March 21, 2017. https://www.edmonton.ca/city_government/documents/PoliciesDirectives/C581.pdf.

48 "Open City Policy," Corporate Service Department. Edmonton, AB. 2015. Accessed March 21, 2017. https://www.edmonton.ca/city_government/documents/PoliciesDirectives/C581.pdf.

49 "Open City Policy". City of Edmonton, Corporate Service Department. City Council document. April 14, 2015. https://www.edmonton.ca/city_government/documents/PoliciesDirectives/C581.pdf.
} 


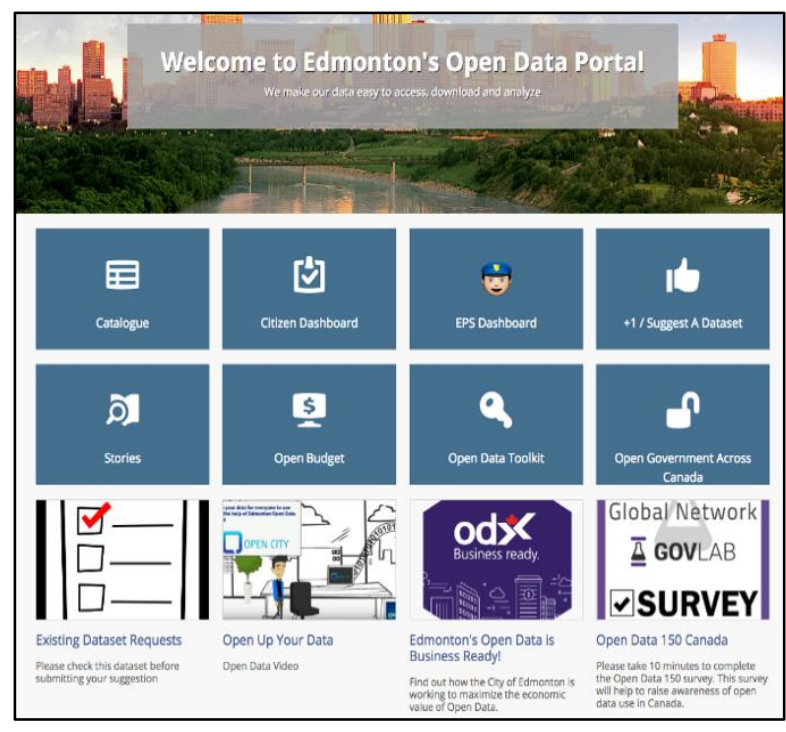

Figure 7 - Snapshot of Edmonton's Open Data Portal webpage (source: https://data.edmonton.ca/)

Edmonton's Open Data Portal, launched in 2010, hosts online datasets published by the city and is a key element of the its Open Data Strategy (see Figure 7) ${ }^{50}$ It is supported in the long term by the Council approved Open City Policy ${ }^{51}$ framework and International Open Data Charter..$^{52}$ Each smart city tool or program is evaluated from an open data perspective using privacy/ownership lenses. Each data collection program involves a Freedom of Information and Protection of Privacy (FOIP) and legal review to determine whether the city administration should release them based on risk assessment. Edmonton also shares information and data in a variety of formats and media and in so doing, adheres to relevant policy, legislation and leading practices related to the privacy and security of personal information. Edmonton subcontracts their open data portal service via Socrata, which allows open data publishers to utilize their software-as-aservice data platform and cloud applications for a fee. The Edmonton Open Data Portal has an Open Data Catalogue that hosts, as of September $7^{\text {th }}, 2017,680$ datasets and a total of 1453 datasets and visualizations to the web. City staff publish these data in a variety of file formats and data schemas and under an open license. The license specifies that the data are free to use and permits data re-users to "copy, modify, publish, translate, adapt, distribute or otherwise use the datasets in any medium, mode or format for any lawful purpose". ${ }^{53}$

The City of Edmonton has received awards for its open data program. In 2015, 2016, and 2017 the city received the highest rating in Public Service Digests' Open Cities Index..$^{54}$ This Index is selfreported to be an open data maturity index, although the methodology for creating the index has not undergone peer or public review. In 2016, the City of Edmonton was awarded the 2016 Canadian Open Data Award for Accessibility by the Open Data Society of British Columbia (OpenDataBC) and OpenNorth at the Canadian Open Data Summit.

Edmonton visualizes open data to better inform the general public about public safety and civic services. For example, the city publishes a map of crime statistics to the web ${ }^{55}$ and their Citizen

\footnotetext{
${ }^{50} \mathrm{https} / / /$ www.edmonton.ca/city_government/documents/PDF/CityofEdmonton_OpenDataStrategy.pdf

51 "Open City Policy". City of Edmonton, Corporate Service Department. City Council document. April 14, 2015. https://www.edmonton.ca/city_government/documents/PoliciesDirectives/C581.pdf.

${ }^{52}$ https://data.edmonton.ca/stories/s/International-Open-Data-Charter/secq-sswa

53 "City of Edmonton Terms of Use," January 2016. Edmonton: AB. https://www.edmonton.ca/city government/documents/Web-version2.1-OpenDataAgreement.pdf.

${ }^{54} \mathrm{https}: / /$ publicsectordigest.com/2016-open-cities-index-top-20-results

55 http://ace.edmonton.ca/projects/visualizations/edmontons-crime-stats/
} 
Dashboard, ${ }^{56}$ that includes a set of performance metrics, which report on the status of government services in relations to proposed targets.

The main customer base for ACE is internal to the municipal organization. However, ACE also has an Open Analytics component focused on demonstrating applications of open source analytics to open data. The Open Analytics team has been involved in conversations between the City, startup companies, and academic institutions to identify how to leverage open source models. Open Analytics has used Tableau and KNIME open source software to visualize and analyze its data via "machine learning, some natural language processing, optimization and anomaly detection". ${ }^{57}$

Finally, Edmonton's Open Science program is a collaboration between Edmonton's Open Data Team and ACE to engage academic and research communities on various projects to improve the city's planning, policy development and efficiency. ${ }^{58}$ The program includes a partnership among researchers, professors, and academic communities for projects related to machine learning, GIS and data mining in multimedia. Collaborations included assisting and giving recommendations on projects and datasets for analysis, ${ }^{59}$ assisting with accessing open data and other data, providing tools and best practices for developing analytics, ${ }^{60}$ and evaluating final projects. ${ }^{61}$ Open Science is a part of the government's Citizen Science Program that falls within the Environmental Strategies unit. Another Citizen Science initiative is a sensor kit to monitor air quality via any Android mobile device. ${ }^{62}$ These kits are available to borrow at Edmonton's public libraries.

\subsubsection{Citizen Engagement}

Residents were not engaged directly in the development of the Smart City Strategy, but the document is reported to reflect the cataloguing of input about previous initiatives. There are plans to engage citizens and private partners to assess and validate the vision, to define future opportunities and to set priorities.

Edmonton's Smart City Strategy is described by smart city representatives as citizen-centric. For Edmonton, citizen engagement includes deploying pilot projects at a small-scale, enabling the community to contribute feedback about the technologies. The BetaCity YEG team, a group of data analysts, programmers, web designers, statisticians, and a range of tech-related skilled citizens host regular meet-ups in Edmonton for addressing local issues; they have also begun a Civic User Testing Group program (modeled after the City of Chicago's initiative) to test the usability of and receive feedback from volunteers about civic tools. BetaCity YEG team is not officially partnered with public officials, however, municipal representatives have financed and used services created by the BetaCity YEG team. For instance, the City has financially sponsored and contributed staff time to various projects which include: the City Environmental Strategies team funding the

\footnotetext{
56 https://dashboard.edmonton.ca/

57 Open City and Technology at the City of Edmonton. Interview with Rachel Bloom. Personal Interview. June 2nd, 2017.

${ }^{58} \mathrm{http}: / /$ ace.edmonton.ca/outreach/open-science/

59 http://ace.edmonton.ca/gis/

${ }^{60}$ http://ace.edmonton.ca/data-mining-in-multimedia/

61 http://ace.edmonton.ca/data-mining-in-multimedia/

62 https://www.edmonton.ca/programs_services/environmental/airbeam-kit.aspx
} 
prototyping of an internet of things-style environmental sensor project, ${ }^{63}$ the development of an open-source social benefits eligibility screening tool, ${ }^{64}$ the development of an open-source pedestrian counter for public space activation monitoring, ${ }^{65}$ SMS-based voting, ${ }^{66}$ and an immediate-needs navigator web application for homeless and low income residents. ${ }^{67}$

According to the Strategy, "engaged citizens participate in government by identifying risks and forming creative solutions". ${ }^{68}$ Engagement with citizens is a part of the city administration's goal of becoming a more resilient city. The Accessibility Advisory Committee's contribution in collaboratively choosing the platform and tools for piloting a crowdsourced accessibility mapping project is an example of co-creating solutions. However, it is not yet publicly specified how and to what extent other groups and their interests identified in the Strategy have informed the smart city vision and goals.

\subsubsection{Deployment of Geospatial and ICT Data}

Approximately 80 percent of the city's data includes georeferenced or geospatial attributes ${ }^{69}$ Much of the data are geocoded by address names, but a lack of standards for address data makes it difficult, at times, to integrate geo-enabled data.

Edmonton's IT branch has established a Spatial Centre of Excellence (SPACE) to respond to challenges related to deployment of spatial data. The SPACE team will examine the city's data and will work on standardizing metadata and reference data when it comes to geographic information. The City is also considering other standards for metadata, such as the Open Geospatial Consortium (OGC) standard for geospatial metadata and the Dublin Core standard. ${ }^{70}$ SPACE is a part of the IT department and has performed location allocation analysis of public services around the city and manages data for on, below, and above ground planning. According to Edmonton's IT branch webpage, ${ }^{71}$ SPACE's approach follows best practices to identify, define, and support corporate spatial needs.

There is currently a discussion within government to update the city's geospatial data infrastructure. Edmonton currently utilizes GeoMedia solutions offered by Integraph, such as their Transportation Manager, IntelliWhere ${ }^{\circledR}$ OnDemand, and other extension products in the GeoMedia suite, to create a collection of user-friendly information. ${ }^{72}$ A leading global provider of Spatial Land Information Management (SLIM) software, Integraph helped the City of Edmonton

\footnotetext{
${ }^{63} \mathrm{https}$ ///betacity.ca/2016/04/23/diy-internet-of-things-lora-or-lorawan-in-edmonton-were-doin-this/

${ }^{64} \mathrm{https} / / /$ betacity.ca/2016/04/09/you-can-benefit-social-benefit-screener-in-progress/

65 https://betacity.ca/2015/11/23/diy-pedestrian-counter/

66 https://betacity.ca/2015/11/22/sms-based-voting/

${ }^{67} \mathrm{https}: / /$ betacity.ca/2015/10/28/linkyeg/

68 "Smart City Strategy 2017". City of Edmonton. Last Modified in 2017.

https://www.edmonton.ca/city_government/documents/PDF/Smart_City_Strategy.pdf

${ }^{69}$ Open City and Technology at the City of Edmonton. Interview with Rachel Bloom. Personal Interview. June 2nd, 2017.

${ }^{70}$ Open City and Technology at the City of Edmonton. Interview with Rachel Bloom. Personal Interview. June 2nd, 2017.

${ }^{71}$ https://www.edmonton.ca/city_government/city_organization/information-technology.aspx

72 "Case Study: City of Edmonton, Alberta". Integraph. 2007. Accessed August 2017. http://www.intergraph.com/global/ca/assets/local/GV_CASE_CityOfEdmonton_SCREEN.pdf.
} 
establish a central repository for GIS data to enable greater access across city government. SLIM includes an Oracle object oriented spatial database, whereby objects have geospatial features and the data are mostly projected into a coordinate system. The Oracle database was chosen because it is tool-agnostic, ensuring that each department may interact with the database with their own tools.

IT and the CIO are responsible for managing the geospatial components of data for the smart city. Spatial data play an important role in Edmonton's smart mobility and open data initiatives. ${ }^{73}$

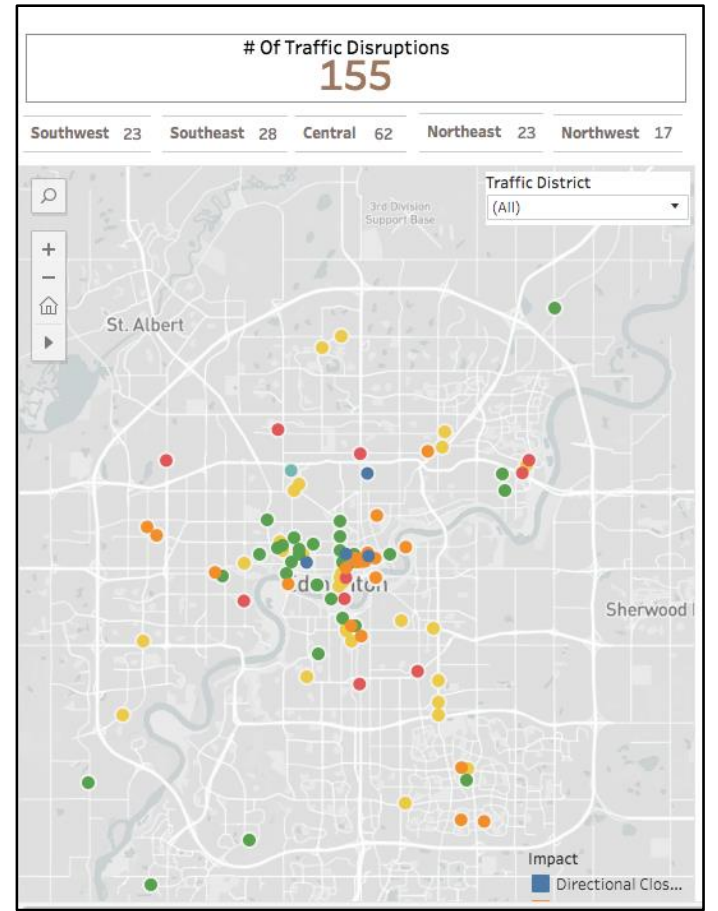

Figure 8 - Snapshot of Edmonton's Open Analytics Traffic Disruptions Map (source:

http://ace.edmonton.ca/portfolio/traff ic-disruptions-map/)

Edmonton's Open Data Portal, GeoEdmonton, ${ }^{74}$ Edmonton Maps, ${ }^{75}$ and the Open Analytics Map ${ }^{76}$ all publish and visualize spatial data openly to the web via applications, such as the Traffic Disruptions Map ${ }^{77}$ and Bike Route Map. ${ }^{78}$ The Bike Route Map displays count data for bicycles, pedestrians, and vehicles based on location, date, time of day, and direction. In addition, traffic movement data are collected via a network of sensors. These data are uploaded by City traffic monitoring staff to Miovision, a Canadian startup. City staff apply proprietary computer algorithms to produce data rich traffic mobility reports, city staff validate a portion of the service's data reporting to ensure 95 percent accuracy of the data. ${ }^{79}$ In addition to vehicles, the systems can also track pedestrian and bike patterns. Staff use the service to move traffic quickly, keep roads in better physical shape, and pursue sustainable transportation goals. Edmonton is also developing a data informed Growth Modelling framework based on spatial forecasting.

Sustainable Development is working on a Growth Modeling Framework as part of Edmonton's Growth Coordination Strategy. ${ }^{80}$ This framework will use a two-lens approach of forecasting and backcasting to track the growth of Edmonton. ${ }^{81}$ Forecasting entails analyzing past and current trends to estimate the future growth of the city's boundaries and its impacts. Backcasting will entail specifying where the city wants to be in the future and estimating what the it needs to do to achieve that state. Builders will use sketch planning via GIS

\footnotetext{
${ }^{73}$ Open City and Technology at the City of Edmonton. Interview with Rachel Bloom. Personal Interview. May $23^{\text {th }}$, 2017.

${ }^{74}$ https://www.edmonton.ca/city_government/initiatives_innovation/geoedmonton.aspx

75 https://maps.edmonton.ca/

${ }^{76}$ https://public.tableau.com/profile/city.of.edmonton\#!/vizhome/OpenAnalyticsMap/OpenAnalyticsMap

$77 \mathrm{http}$ ://ace.edmonton.ca/portfolio/traffic-disruptions-map/

${ }^{78}$ www.ace.edmonton.ca/portfolio/bike-route-map/

$79 \mathrm{https}$ ://transformingedmonton.ca/eyes-on-intersections-doing-more-with-less-for-better-traffic-flow/

80 https://www.edmonton.ca/city_government/urban_planning_and_design/growth-analysis.aspx

81 https://www.edmonton.ca/city_government/documents/PDF/Growth-Modelling-Framework.pdf
} 
and data-based tools to produce general estimates of transportation and land use demand and impacts. This framework is currently under development and it is not yet clear what analytical tools, decision making processes, and data will be used for the framework by city staff.

There is a category for open geospatial data on Edmonton's Open Data Catalogue portal, and many online and interactive maps are available by search on the open data catalogue. Other open spatial data can be ingested and used by developers via the Socrata Open Data API (SODA). Data can also be downloaded in multiple open and machine-readable formats. There are also a variety of mapping apps that offer Location Based Services (LBS) for recreation, transit, building age, property assessment, and building footprints and these are available in the Open Data Catalogue. ${ }^{82}$

Currently, the Edmonton is working on what they currently refer to as the One City Data Hub. ${ }^{83}$ This hub will be a centralized destination for City-generated data for internal city staff. The City of Edmonton plans to use this corporate data warehouse to inform internal decision-making. Any non-sensitive data is expected to eventually be published on the city's open data platform cloud service provided by Socrata. The One City Data Hub includes spatial and non-spatial data, and will help to create more analytics and visualizations for the data. Edmonton is currently pushing data collected from sensors to the Open Data catalogue, such as near real-time rainfall data and the GPS location of Edmonton Transit Service buses.

Data sharing agreements exist between the City of Edmonton and post-secondary institutions such as the University of Alberta data library and other research centres. Data ownership remains with the city when negotiating these data sharing agreements.

Furthermore, the IT Vendor \& Contract Office manages, administers and guides interactions with IT service providers to ensure optimal benefits for the city. ${ }^{84}$ Its key functions include Service Level Management, Performance Manager, Relationship Management, and Risk Management. This new approach was introduced in 2016 and extends itself to the rest of the IT's vendor community beginning in 2017. Moreover, the city secures its data centrally via firewalls and perimeter networks and limits internal access to the data throughout government. According to Edmonton's website, an IT Security, Risk Management, Compliance \& Audit team oversees all IT controls and processes, monitors progress to risk treatments, and serves as a liaison on all IT audits. ${ }^{85}$ What remains unclear is what information handling best practices the team adheres to or how they are evolving with smart city plans. These best practices apply generally to all City technology.

The City Clerk sets retention timelines for the city's data records. These timelines are deployed in the Corporate Records and Information Management Office, which is overseen by the Office of the City Clerk. ${ }^{86}$ Guidelines and timelines for archiving data are made available through routine disclosure.

\footnotetext{
82 https://data.edmonton.ca/applications

${ }^{83}$ Open City and Technology at the City of Edmonton. Interview with Rachel Bloom. Personal Interview. May $23^{\text {th }}$, 2017.

${ }^{84}$ https://www.edmonton.ca/city_government/city_organization/information-technology.aspx

85 https://www.edmonton.ca/city_government/city_organization/information-technology.aspx

${ }^{86} \mathrm{https}$ ://www.edmonton.ca/city_government/city_organization/corporate-records-management.aspx
} 


\subsubsection{Summary and Observations}

Edmonton, like many cities globally, is transitioning toward becoming a smart city. Table 2 below demonstrates how Edmonton's smart city initiative, despite being in its early days, is rather advanced due to its official strategy, a governance structure consisting of a full time and dedicated unit with a director, and integration with the municipal overall strategic plan. It is also noteworthy that Edmonton's Smart City Strategy and its goals of resiliency, livability, and workability, resemble the International Smart Cities Council's definition of a smart city as being "livable", "workable", and "sustainable". ${ }^{87}$

Table 2 below summarizes what has been gleaned from the E-Scan and discussions with City officials. It is expected that as the Smart City Strategy is rolled out, challenges related to personal privacy, data security, data standards and data management, interoperability and resident engagement will be addressed in the open. In addition, while Edmonton remains committed to their Open City Initiative and Policy, we await to see how the smart city will actively integrate and uphold open city principles in all components of the smart city.

It is anticipated that government will focus on how it will integrate civil society into the smart city governance structure and further acknowledges that there is a role for communicating the Smart City Strategy and its impacts. We await to see how experienced actors from other sectors (academia, civil society, etc.) become involved in developing the roadmap and governing in a formal fashion, either as part of the leadership committee or as part of an advisory capacity in a formal council or committee. In addition, it remains unclear how Edmonton will decide to integrate existing strategies and expertise on data archiving procedures, geospatial modeling and spatial data infrastructures, cybersecurity, and privacy when deploying IoT technologies and Software as a Service (SaaS). In other words, we look forward to seeing how the smart city will make linkages across departments and areas of expertise to ensure an urban operating model that is secure, open, and oriented around the needs of residents and small and medium enterprises (SMEs).

Finally, it will be interesting to see if the smart city representatives for the city will gear its smart city goals of resiliency, livability and workability in such a way as to not only better and innovatively serve the community and to tackle the problem sets it has identified, but also to model new approaches to transportation, affordable housing and climate change reduction. We also look forward to observing how the city will leverage a community of civic technology groups along with the private sector to provide for safe, ethical, privacy and transparency by design, accessible and commonly owned solutions. We hope these key considerations will appear in the upcoming roadmap for the smart city.

${ }^{87}$ https://smartcitiescouncil.com/article/about-us-global 
Table 2 - Summary of the City of Edmonton Smart City Initiative

\begin{tabular}{|c|c|c|}
\hline $\begin{array}{c}\text { Smart City } \\
\text { Component/Process }\end{array}$ & Current State & $\begin{array}{c}\text { Considerations for } \\
\text { the Future }\end{array}$ \\
\hline Smart City Strategy & Smart City Strategy (2017) & -- \\
\hline $\begin{array}{c}\text { Smart City } \\
\text { Roadmap \& } \\
\text { Guiding Principles }\end{array}$ & In progress. & Forthcoming \\
\hline Urban Plan & $\begin{array}{l}\text { Is integrated with the Strategic Plan, } \\
\text { The Way Ahead 2008-2018 (updated in } \\
\text { 2014); Is not linked directly to the The } \\
\text { Way We Grow, }{ }^{88} \text { the municipal } \\
\text { development plan. }\end{array}$ & $\begin{array}{l}\text { Will The Way We } \\
\text { Grow integrate and } \\
\text { mandate smart city } \\
\text { components? }\end{array}$ \\
\hline $\begin{array}{l}\text { Governance } \\
\text { Structure }\end{array}$ & $\begin{array}{l}\text { Is situated within Financial and } \\
\text { Corporate Services; Has strong } \\
\text { leadership from CIO and CFO; Has an } \\
\text { Executive Leadership Committee made } \\
\text { up of Key Branch Managers and } \\
\text { includes collaboration with other units; } \\
\text { Plans to include citizen representation } \\
\text { on the smart city leadership committee; } \\
\text { Does not specify how civic technology } \\
\text { representatives will be incorporated. }\end{array}$ & $\begin{array}{l}\text { How will the } \\
\text { general public be } \\
\text { integrated into the } \\
\text { governance } \\
\text { structure? Will } \\
\text { citizens have a } \\
\text { decision making role } \\
\text { and be empowered? } \\
\text { What kind of role } \\
\text { will civic } \\
\text { technology and civil } \\
\text { society groups play } \\
\text { in the governance } \\
\text { structure? }\end{array}$ \\
\hline Dedicated Personnel & $\begin{array}{l}\text { Includes a Smart City Director, Smart } \\
\text { City Unit, ACE, Open Data, and Spatial } \\
\text { Analytics. }\end{array}$ & $\begin{array}{l}\text { Will there be } \\
\text { dedicated legal, } \\
\text { privacy and security } \\
\text { personnel/function? }\end{array}$ \\
\hline Dedicated Unit & $\begin{array}{l}\text { Smart City \& Open City Unit, ACE, } \\
\text { Open Data, and Spatial Analytics Unit. }\end{array}$ & $\begin{array}{l}\text { Will there be } \\
\text { dedicated legal, } \\
\text { privacy and security } \\
\text { personnel/function? }\end{array}$ \\
\hline
\end{tabular}

${ }^{88} \mathrm{https}: / /$ www.edmonton.ca/city_government/documents/PDF/MDP Bylaw_15100.pdf 


\begin{tabular}{|c|c|c|}
\hline $\begin{array}{l}\text { Inventory of } \\
\text { initiatives }\end{array}$ & Is presented in the Smart City Strategy. & $\begin{array}{l}\text { What constitutes a } \\
\text { smart city } \\
\text { program/project? } \\
\text { What is systematic } \\
\text { about the decision } \\
\text { process? }\end{array}$ \\
\hline Procurement & $\begin{array}{l}\text { Includes examining changes that will } \\
\text { allow for implementing flexible pilots. }\end{array}$ & $\begin{array}{l}\text { What will the } \\
\text { guding principles be } \\
\text { for procuring smart } \\
\text { city technologies? } \\
\text { Will terms such as } \\
\text { open source, open } \\
\text { standards, privacy } \\
\text { and transparency by } \\
\text { design, and } \\
\text { cybersecurity } \\
\text { standards guide } \\
\text { requests? Will the } \\
\text { city retain data, } \\
\text { hardware and } \\
\text { software IP? }\end{array}$ \\
\hline Engagement & $\begin{array}{l}\text { Is discussed, but the general public is } \\
\text { not directly engaged by the Smart City } \\
\text { Steering Committee as of yet, and civil } \\
\text { society (makers, civic tech, NGOs) are } \\
\text { not part of the governance structure; } \\
\text { The Smart City Strategy mentions } \\
\text { outreach to community groups and } \\
\text { some plans are informed by earlier } \\
\text { consultations with stakeholders (e.g., } \\
\text { crime analytics). }\end{array}$ & $\begin{array}{l}\text { While civic } \\
\text { engagement is a } \\
\text { priority, how will } \\
\text { "smart citizens" be } \\
\text { empowered and } \\
\text { included in a } \\
\text { decision making } \\
\text { capacity? }\end{array}$ \\
\hline Openness & $\begin{array}{l}\text { Includes an Open Data Portal with open } \\
\text { formats, open performance indicators, } \\
\text { open maps and data, an open data } \\
\text { license, a proprietary Socrata platform; } \\
\text { City has an Open City Initiative and } \\
\text { Policy; There are no specific plans for } \\
\text { meaningful public engagement beyond } \\
\text { hackathons; It is uncertain if there is an } \\
\text { open source strategy. }\end{array}$ & $\begin{array}{c}\text { Will open source be } \\
\text { part of being an } \\
\text { open smart city? }\end{array}$ \\
\hline
\end{tabular}




\begin{tabular}{|c|c|c|}
\hline Spatial Data & $\begin{array}{l}\text { Most data are geo-referenced and } \\
\text { addresses are geocoded; Mapping } \\
\text { services and many data are shared in } \\
\text { open formats on the Open Data } \\
\text { Catalogue; Government has a dedicated } \\
\text { spatial planning unit; Policies for open } \\
\text { standards and specifications for } \\
\text { geospatial information are under } \\
\text { development. }\end{array}$ & $\begin{array}{l}\text { How will cities } \\
\text { utlimately decide on } \\
\text { the adoption or } \\
\text { rejection standards } \\
\text { for integrating } \\
\text { geospatial data? } \\
\text { How will data be } \\
\text { geocoded? Will } \\
\text { there be any } \\
\text { framework data } \\
\text { shared? }\end{array}$ \\
\hline Crowdsourcing & $\begin{array}{l}\text { City government has their Citizen } \\
\text { Science and Open Science programs. }{ }^{89}\end{array}$ & $\begin{array}{l}\text { What role will } \\
\text { crowdsourcing play } \\
\text { in the Smart City } \\
\text { Strategy? How will } \\
\text { the "Idea Generator" } \\
\text { influence the } \\
\text { decision making } \\
\text { process and translate } \\
\text { ideas into action? }\end{array}$ \\
\hline \multirow[t]{2}{*}{$\begin{array}{c}\text { Standards \& } \\
\text { Interoperability }\end{array}$} & $\begin{array}{l}\text { The is no formal smart city standards } \\
\text { strategy or public statement; Edmonton } \\
\text { is aware of OGC standards for } \\
\text { metadata; There is the adoption of open } \\
\text { formats for open data and APIs (SODA } \\
\text { API) for open data; Dublin Core, a } \\
\text { standard for metadata, is being } \\
\text { considered for ICT data }\end{array}$ & \multirow{2}{*}{$\begin{array}{l}\text { How will the One } \\
\text { City Data Hub } \\
\text { integrate the data? } \\
\text { Will interoperabiliy } \\
\text { of software and data } \\
\text { be specified and } \\
\text { will the smart city } \\
\text { be a platform that } \\
\text { others plug into? }\end{array}$} \\
\hline & $\begin{array}{l}\text { Edmonton is working on centralizing } \\
\text { and integrating data in a corporate } \\
\text { warehouse via what is referred to as the } \\
\text { One City Data Hub. }\end{array}$ & \\
\hline
\end{tabular}

\footnotetext{
${ }^{89} \mathrm{https://www.edmonton.ca/programs \_ services/environmental/citizen-science.aspx}$
} 


\begin{tabular}{|c|c|c|}
\hline Privacy & $\begin{array}{l}\text { Privacy impact assessments reside with } \\
\text { the City Clerk; City uses a privacy-by- } \\
\text { design approach to assessments; City } \\
\text { organization conducts privacy impact } \\
\text { assessments per FOIP for all IT across } \\
\text { branches; Privacy issues related to } \\
\text { publishing open data are identified by } \\
\text { legal administrators; There are not yet } \\
\text { guidelines or policies specifically for } \\
\text { IoT deployment. }\end{array}$ & $\begin{array}{l}\text { Will methods of } \\
\text { privacy impact } \\
\text { assessments evolve } \\
\text { with emergent smart } \\
\text { city technologies } \\
\text { and IoT? }\end{array}$ \\
\hline Security & $\begin{array}{l}\text { City implements perimeter systems and } \\
\text { firewalls for data that is linked to the } \\
\text { cloud and limits internal access to data; } \\
\text { Security assessment for all IT is } \\
\text { conducted by the IT Security, Risk } \\
\text { Management, Compliance and Audit } \\
\text { Team. }\end{array}$ & $\begin{array}{l}\text { What security } \\
\text { standards and } \\
\text { practices will be } \\
\text { applied in a smart } \\
\text { city context, such as } \\
\text { for data captured by } \\
\text { meters and sensors } \\
\text { and at the device } \\
\text { level? }\end{array}$ \\
\hline Archiving & $\begin{array}{l}\text { There is a records management strategy } \\
\text { for city information that is made } \\
\text { available through routine disclosure. }\end{array}$ & $\begin{array}{l}\text { How will data } \\
\text { preservation be } \\
\text { considered with } \\
\text { emergent smart city } \\
\text { technologies, } \\
\text { especially data } \\
\text { derived from IoT or } \\
\text { SaaS? Will } \\
\text { archiving and data } \\
\text { retention best } \\
\text { practices be part of } \\
\text { the Smart City } \\
\text { Strategy or the } \\
\text { forthcoming } \\
\text { roadmap? }\end{array}$ \\
\hline
\end{tabular}




\subsection{City of Guelph}

The City of Guelph, one of the first planned towns in Canada, was founded in 1827 and was officially incorporated as a city in $1879 .{ }^{90}$ It is a small rural city located in Southwestern Ontario, situated on the traditional territory of the Neutral, Anishinaabeg, Haudenasaunee and Métis Peoples. The City has a 2016 Census population of $131,794,{ }^{91}$ with a population growth of $8.3 \%$. It is about a 1.5-hour drive from the city of Toronto and is approximately 30 minutes away from Kitchener-Waterloo.

Guelph is a single-tier municipality and is governed by a mayor-council system with 12 city councilors who oversee 6 wards. The City has approximately 1,900 full and part-time employees ${ }^{92}$ and makes its strategic plans accessible online. ${ }^{93}$ The City's Corporate Administrative Plan, Focusing on What Matters, is published on the Guelph's website and specifies goals of service excellence, financial stability, and innovation (see Figure 9). It is also accompanied by the Initiatives Status Dashboard ${ }^{94}$ that reports on the progress of the plan and its three programs:

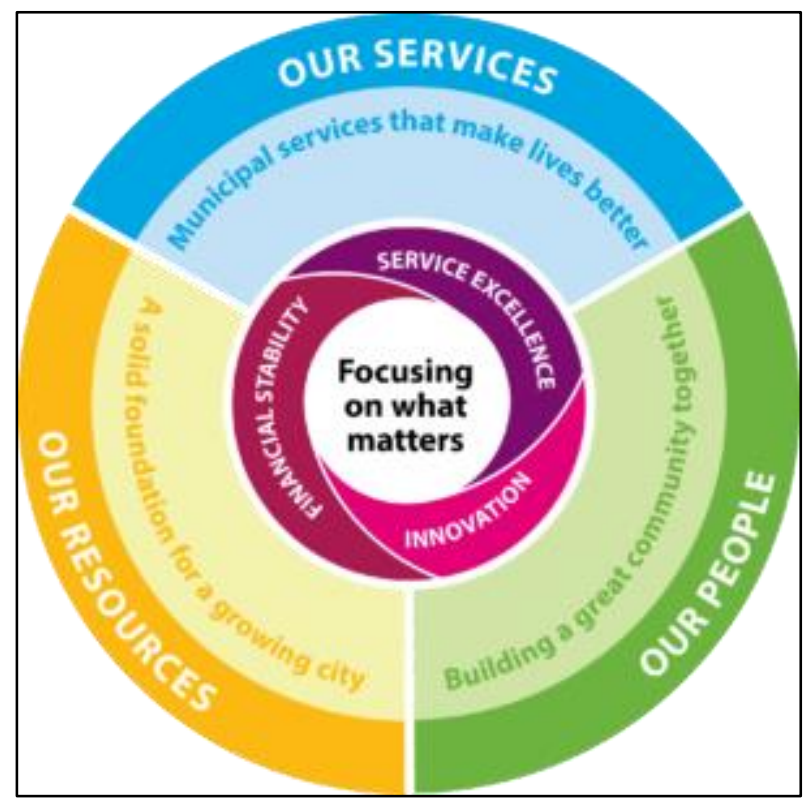

Figure 9 - Visual of City of Guelph's Corporate Administrative Plan (source: https://guelph.ca/2016/09/city-guelphreleases-corporate-administrative-plan/) service modernization program, leadership and engagement, and sustainable resources program.

Guelph promotes a diverse economy consisting of various industries. While small, it is home to the University of Guelph, (one of the top Agricultural Universities with 23,000 students), the Province of Ontario's Ministry of Agricultural and Rural Affairs, and a General Hospital. It is also within $25 \mathrm{KM}$ of the universities of Waterloo, Wilfrid Laurier and Conestoga College. ${ }^{95}$ The city's population is generally well-off, with an average household income of $\$ 83,000$ and a workforce that is primarily professional, scientific and technical; core sectors include advanced manufacturing, agri-innovation with burgeoning ICT and green technology sectors, ${ }^{96}$ and the city attracts many entrepreneurs. ${ }^{97}$ In addition, Guelph is considered to be an agri-tech cluster ${ }^{98}$ and

\footnotetext{
${ }^{90}$ http://guelph.ca/living/about-guelph/

${ }^{91}$ http://www12.statcan.gc.ca/census-recensement/2016/dp$\mathrm{pd} / \mathrm{prof} /$ details/page.cfm?Lang=E\&Geo1=CSD\&Code1=3523008\&Geo2=CD\&Code2=3523\&Data=Count $\&$ Search $\underline{\text { Text }=\text { Guelph } \& \text { SearchType }=\text { Begins } \& \text { SearchPR }=01 \& B 1=A l l \& T A B I D=1 \# \text { map-popup }}$

92 http://guelph.ca/employment-careers/

93 http://guelph.ca/living/environment/

94 https://guelph.ca/plans-and-strategies/corporate-strategic-plan/cap-dashboard/

95 http://guelph.ca/wp-content/uploads/Quicksheet July2017 x1a.pdf

96 http://guelph.ca/wp-content/uploads/2016-2017GuelphCommunityProfile.pdf

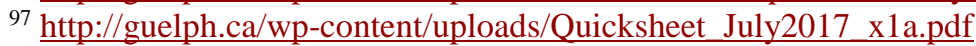

98 http://guelph.ca/wp-content/uploads/Strategic_Plan_for_the_Guelph_Agri-Innovation_Cluster.pdf
} 
provides incentives for new businesses to locate there. ${ }^{99}$ Guelph relies on groundwater for its water supply, and prioritizes its water conservation and environmental efforts as well as its green technology cluster. ${ }^{100}$

\subsubsection{Foundations for a Strategy}

Guelph is in the process of determining what a smart city might mean for the administration and for the city overall. The City of Guelph does not currently have an official smart city strategy, framework, or roadmap, but it does have a Corporate Technology Strategic Plan ${ }^{101}$ that provides some direction for the smart city. Guelph's government nonetheless communicates a number of smart city goals and has deployed a number of ongoing smart city activities, which will be described in more detail below.

The City of Guelph's vision and definition for a smart city originates from its 2012 Corporate Technology Strategic Plan:

The vision of a modern City is one that offers services to customers when and where they want them. A Smart City is one that uses technology to achieve this goal, using technology at every appropriate opportunity to streamline processes and simplify access to city services. This is a city that has all the information it needs, available and accessible, to support effective decision-making. This is a City in which technology underpins the processes needed to deliver streamlined and efficient services to customers. ${ }^{102}$

A professional consulting firm, Prior \& Prior Ltd., assisted in the development of Guelph's Corporate Technology Strategic Plan and consulted with members of City Council, the Executive Team, program managers, IT management, city staff, and external partners to inform the plan's development. The smart city initiative signals a cultural shift for the administration in terms of how the government views, manages, and invests in technology, and will likely influence the organization's strategic pathway to becoming a smart city.

Guelph's Technology Strategic Plan suggests that a modern smart city uses citizen-centric digitized platforms to manage and automate its public services. According to a City contact in IT Projects, citizen centric platforms are any system or solution that is built with the citizen point of view in mind, in terms of how they interact with the tool. Modernized digitized services are interconnected across information management systems, delivered over the internet as a priority, and enable government to share government data openly with the public. ${ }^{102}$ The objective of the Corporate Technology Strategic Plan is to lead Guelph toward becoming a smart city and the IT Steering Committee is tasked with developing a priority technology project list and drafting an annual technology budget.

\footnotetext{
${ }^{99}$ http://guelph.ca/wp-content/uploads/BDE_AnnualReport2014.pdf

${ }^{100} \mathrm{http}: / / g u e l p h . c a /$ living/environment/water/

101 http://guelph.ca/wp-content/uploads/CorporateTechnologyStrategicPlan.pdf

102 “Corporate Technology Strategic Plan: Final Report," Prior \& Prior Associates Ltd. August 2012. Accessed April 3, 2017. http://guelph.ca/wp-content/uploads/CorporateTechnologyStrategicPlan.pdf.
} 
The City of Guelph anticipates incorporating smart city components into the municipal Corporate Administrative Plan, Focusing on What Matters. ${ }^{103}$ Smart city initiatives and target areas will be prioritized according to the level of interest by the organization's political leadership and staff availability. Furthermore, public consultations will be part of the process for setting smart city focus areas.

\subsubsection{Perceived Beneficiaries}

Guelph's smart city is designed to benefit citizens, civil society organizations, the private sector and city staff, however, government does not yet have a communication strategy in place to publicize and report on how the smart city will benefit these beneficiaries.

Municipalities, universities, school boards, and hospitals (MUSH) are also considered to be potential beneficiaries of the smart city because these organizations could potentially use and emulate the municipality's use of successful technologies.

\subsubsection{Smart City Components}

Even without an official smart city strategy, the City of Guelph has deployed smart environmental and energy initiatives, digital public services and platforms, an open data program, data-based indicators, and innovative approaches for procuring technology. Table 3 lists projects that the City of Guelph has participated in and also relates each of them to smart city components.

Table 3 - List of smart city related projects for the City of Guelph

\begin{tabular}{|c|c|}
\hline Project & Smart City Components \\
\hline $\begin{array}{l}\text { District Energy } \\
\text { Strategic Plan }\end{array}$ & Smart energy, smart meters, smart grid, district energy systems \\
\hline$\frac{\text { Grid Smart City }}{\text { Cooperative }}$ & Smart energy \\
\hline$\frac{\text { Water/energy rebate }}{\text { programs }}$ & Smart energy, smart citizens \\
\hline$\frac{\text { Civic Accelerator }}{\underline{\text { Program }}}$ & $\begin{array}{l}\text { Smart city accelerator, procurement best practices, technology } \\
\text { startups, smart governance }\end{array}$ \\
\hline$\frac{\text { Guelph Innovation }}{\text { District (GID) }}$ & Economic cluster, innovation, technology businesses \\
\hline$\underline{\text { myGuelph }}$ & $\begin{array}{l}\text { Civic engagement, service dashboards, smart citizens, geo- } \\
\text { visualization of open data, digital public services, open government }\end{array}$ \\
\hline
\end{tabular}

103 IT Projects, Strategy and Digital at the City of Guelph. Interview with Rachel Bloom. Personal Interview. May $25^{\text {th }}, 2017$. 


\begin{tabular}{|c|c|}
\hline Open Data Guelph & $\begin{array}{l}\text { Open data, open data catalogue, open license, open government, } \\
\text { GTFS transit data }\end{array}$ \\
\hline Open Guelph & Open government \\
\hline$\frac{\text { Open Government }}{\underline{\text { Action plan }}}$ & Open government \\
\hline$\frac{\text { Corporate GIS Strategic }}{\underline{\text { Plan }}}$ & GIS, public service provision, open data standards \\
\hline $\begin{array}{l}\text { Guelph Community } \\
\text { Well Being Indicators }\end{array}$ & Smart community indicators \\
\hline $\begin{array}{l}\frac{\text { Corporate Technology }}{\text { Strategic Plan }}{ }^{104} \\
\underline{\text { S }}\end{array}$ & $\begin{array}{l}\text { ICT strategy, includes a smart City vision, roadmap, and proposed } \\
\text { governance structure }\end{array}$ \\
\hline$\frac{\text { Guelph Map App: }}{\underline{311 \mathrm{GIS}}}$ & Digital services platform, open data standards \\
\hline$\underline{\text { Sort Right }}$ & Digital service platform \\
\hline$\frac{\text { Online payment system }}{\underline{\text { for taxes and fines }}}$ & Digital public services \\
\hline $\begin{array}{c}\text { Open Source } \\
\text { Procurement Strategy } \\
\underline{\text { and Best Practices }}\end{array}$ & Open source, open city, open government action plan \\
\hline$\frac{\begin{array}{c}\text { Guelph Lab's } \\
\text { Procurement Lab }\end{array}}{\text { project }}$ & Smart business models, technology accelerators \\
\hline Open Budge Simulator & Open government, open data \\
\hline$\frac{\text { NextBus and GTFS }}{\text { transit data }}$ & Mobility, smart transportation \\
\hline $\begin{array}{c}\frac{\text { Service Modernization }}{\underline{\text { Program (in }}} \\
\underline{\text { development) }}\end{array}$ & $\begin{array}{l}\text { Performance dashboards, Citizen Relationship Management } \\
\text { technology solution, myGuelph }\end{array}$ \\
\hline
\end{tabular}

${ }^{104}$ http://guelph.ca/plans-and-strategies/corporate-gis-strategic-plan/ 


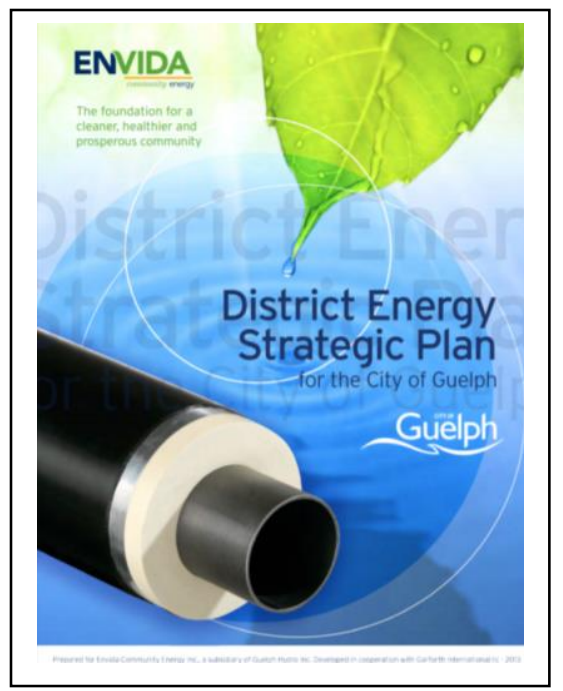

Figure 10- Snapshot of City of Guelph's District Energy Strategic Plan (source: https://guelph.ca/plans-andstrategies/community-energyinitiative/district-energystrategic-plan/)

\subsubsection{Smart Energy and Environment}

The municipality has a program that offers rebates to residents who purchase more efficient devices for water consumption and has implemented a program to install solar panels on top of municipal buildings in collaboration with GridSmartCity, a utility partner cooperative that aims to improve energy efficiency and distribution. ${ }^{105}$ As part of municipal water conservation efforts, the Guelph offers a rebate on the purchase of water conservation sensor kits to detect leaks and floods. The kits deliver real time data and alerts via email, text or an app. ${ }^{106}$

The City of Guelph's energy initiative, which was endorsed by Council in 2006, led to the development of a District Energy Strategic Plan. ${ }^{107}$ In 2013, Envida Community Energy commissioned the plan for a district energy system to supply at least 50 percent of heating to institutional, commercial, industrial, and residential buildings. ${ }^{108}$

On May 12, 2014, City Council also approved a plan to develop a Guelph Innovation District (GID). The GID is an economic cluster focused on green-economy and innovation sector jobs. ${ }^{109}$ GID includes a new urban village, a mixed-use main street, a research park and an adaptive re-use area around the historic reformatory complex. ${ }^{110}$ City officials believe that GID will lead to innovations focused on addressing climate change and waste management.

\subsubsection{Innovative Procurement}

The Guelph Civic Accelerator ${ }^{111}$ has demonstrated innovative procurement practices and is a part of the city's open data program. It is a partnership between municipal public officials, Innovation Guelph, Canada's Open Data Exchange (ODx), the University of Guelph,

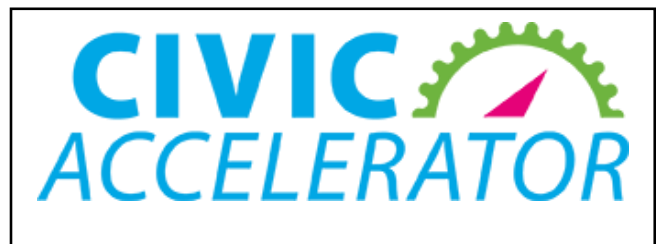
the Guelph Lab, and the Guelph Chamber of Commerce. The Civic Accelerator program seeks technology-based solutions to a number of municipal challenges; specifically, representatives from various municipal departments announced their interest in a service or product that enables citizens to (1) detect water leakages and reduce their water consumption; (2) maximize parking in the

\footnotetext{
105"Guelph Community Energy Initiative," GridSmartCity. Last modified January 10, 2012. http://gridsmartcity.com/guelph-community-energy-initiative/.

106 https://alertlabs.com/pages/guelph-rebate

107 “Guelph District Energy Strategic Plan," City of Guelph, Envida Community Energy, International Inc. January 2013. Accessed March 24, 2017. http://guelph.ca/wp-content/uploads/011514_DistrictEnergyStrategicPlan_web.pdf 108 http://www.envida.ca/en/aboutus/aboutus.asp

${ }^{109} \mathrm{http}: / /$ svn-ap.com/projects/abc-project/

${ }_{110} \mathrm{http} / / / g u e l p h . c a / 2014 / 05 /$ council-approves-plan-innovation-district-guelphs-east-end/

111 http://open.guelph.ca/accelerator/
} 
downtown area, and (3) contribute more feedback to government on urban planning decisions. ${ }^{112}$ City officials identified departments that were open to new procurement methods and had the resources to support its implementation. Qualifying departments then identified the three issues for the program that did not lend to traditional procurement methods or traditional market solutions. ${ }^{113}$

The City of Guelph also ensures to specify the retention of data's ownership when procuring IT. Ownership of data is written into calls for tender and then agreed upon at the time of acquisition of a service or product. It is also common practice to include a license termination clause within the legal data sharing agreement to ensure data ownership remains with the public agency. ${ }^{114}$

Guelph has also sought opportunities to co-procure smart technology, such as fiber optic cables, with other public organizations (i.e., municipalities, universities, school boards and hospitals).

\subsubsection{Data-based Indicators and Dashboards}

Components of the smart city are monitored and guided by departmental indicators and benchmarking systems. ${ }^{115}$ For instance, Guelph posts annual performance report cards ${ }^{116}$ and launched a public facing performance reporting dashboard with metrics for measuring City operations (see Figure 11). ${ }^{117}$

\subsubsection{Governance}

The City of Guelph, along with developing smart city plans, is redesigning its IT Governance Committee. This overarching Committee is now the governing body for the smart city and includes members of the muncipal

\section{The Count (BETA testing phase)}

The City of Guelph's performance reporting dashboard

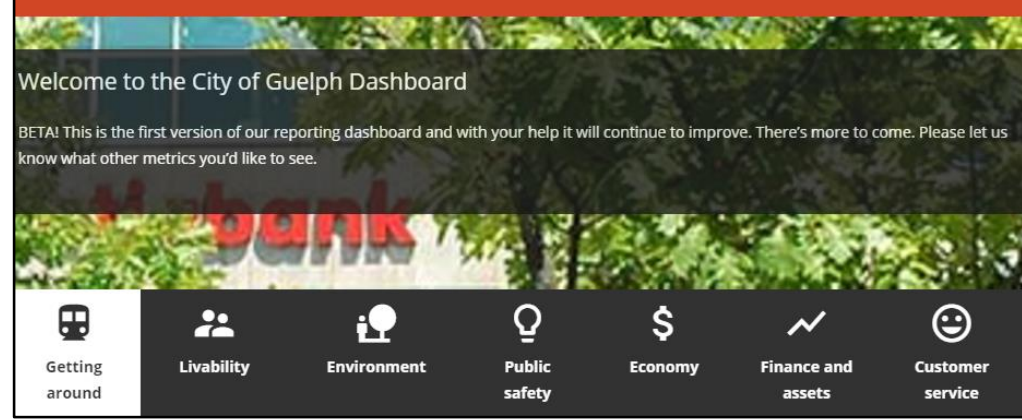

Figure 11 - Snapshot of City of Guelph's Performance Reporting Dashboard (beta-version) (source: https://guelph.ca/city-hall/city-administratorsoffice/strategic-planning-corporate-initiatives/publicreporting/performance-dashboard/) Executive Committee, such as The

\footnotetext{
112 "The Challenges," Civic Accelerator. Accessed March 16, 2017. http://open.guelph.ca/accelerator/challenges/.

${ }^{113}$ http://brookfieldinstitute.ca/wpcontent/uploads/2017/06/GuelphCivicAccelerator_CasesStudyReport_BrookfieldInstitute.pdf

114 IT Projects, Strategy and Digital at the City of Guelph. Interview with Rachel Bloom. Personal Interview. May $25^{\text {th }}, 2017$.

115 IT Projects, Strategy and Digital at the City of Guelph. Interview with Rachel Bloom. Personal Interview. May $25^{\text {th }}, 2017$.

116 http://guelph.ca/city-hall/budget-and-finance/performancereports/

${ }^{117}$ http://guelph.ca/city-hall/city-administrators-office/strategic-planning-corporate-initiatives/publicreporting/performance-dashboard/
} 
Chief Administrative Officer and Deputy Chief Administration Officers. A new Digital Group will be formed and will be part of the IT Governance Committee; this group will develop the Guelph's smart city strategy. ${ }^{118}$ The original responsibilities for the IT Governance Committee were primarily software centric and focused on adopting and updating corporate applications. The redesigned IT Governance Committee will broaden their focus and include the following subcommittees: digital, security and physical location security, innovation/service evolution, GIS, and, to some extent, citizens. Each subcommittee is responsible for devising a plan for engagement with citizens. These subcommittees will be responsible for the operationalization of the smart city.

The IT Governance Committee will examine the smart city initiatives of other similar-sized cities to assess best practices and will solicit the opinion of citizens with a survey. The results of this research will provide direction to the Digital Group working on Guelph's smart city.

\subsubsection{Procurement}

There does not appear to be a set of guiding principles for procuring smart city technologies, although as discussed, there are agreed upon practices to ensure that data remain the IP of the city. Additionally, the city aims to partner, via knowledge sharing, co-procuring, and the cross populating of implementation teams with other organizations (i.e., municipalities, universities, school boards, and hospitals) to procure smart city technologies.

Guelph has reformed the Request for Proposals (RFP) process to make the procurement process more accessible to smaller vendors, such as startups and SMEs. Guelph's Civic Accelerator Program demonstrates simplified procurement processes for new ideas that are presented to government. The vision is to build an environment where business and government feel comfortable experimenting with these new products and services. Specifically, the program aims to help companies innovate and bring new products and services to market and encourages the development of procurement best practices for the City of Guelph. ${ }^{119}$

Moreover, the City of Guelph's Open Government Framework supports the procurement of open source technologies ${ }^{120}$ and recommends the adoption of the UK Open Source Procurement toolkit. ${ }^{121}$ The model enables municipal government to consider open source solutions alongside proprietary based solutions. In addition to this strategy, there is a requirement in City RFPs which includes citizen input. The mechanism for collecting input on services is the myGuelph Portal, which doubles as the government's public-facing Citizen Relationship Management (CRM) system. ${ }^{122}$

\footnotetext{
118 IT Projects, Strategy and Digital at the City of Guelph. Interview with Rachel Bloom. May 25 2017.

119 "Civic Accelerator," City of Guelph. Accessed March 16, 2017. http://open.guelph.ca/accelerator/.

120 "Open Government Framework," Committee Report - Corporate and Human Resources, City Clerks Department. November 2012. http://guelph.ca/wp-content/uploads/GuelphOGF_Framework_Nov2012.pdf. 121 "All about Open Source: An Introduction to Open Source Software for Government IT V2.0," UK government. April 2012. http://www.gov.uk/government/uploads/system/uploads/attachment_data/file/78959/Akk_About_Open Source_v2_0.pdf

122 http://www.guelphlab.ca/procurement-lab-project/
} 


\subsubsection{Openness}

An essential component of openness for Guelph involves publishing performance indicators for City services, even when the government is not meeting a proposed target. ${ }^{123}$ The city will develop an Accountability and Performance Management Framework to improve government service accountability and transparency as part of their Modernization Program. Specifically, the framework will build on, "good practices already in the City and provide a clear set of expectations, continuous improvement processes, performance dashboards and employee training". ${ }^{124}$

Guelph City Council adopted an Open Government Framework in November of 2012, ${ }^{125}$ which outlines their vision, guiding principles and directions for open government (see Figure 12). The framework includes open data, open engagement with citizens, access to information, and open governance, ${ }^{126}$ and informs the Open Government Action Plan, released by the city in 2014. The Action Plan includes data standards, a data inventory, and organizational data champion(s).

The City of Guelph publishes open data sets on their Open Data Guelph ${ }^{127}$ website. Open data stewards and data custodians are assigned responsibility of datasets published on the website. The open data catalogue is powered by the Comprehensive Knowledge Archive Network (CKAN), an open source platform. Datasets are mostly published in machine-readable, proprietary, and non-proprietary file formats. The selection of datasets is based on a survey and an assessment report produced by Public Sector Digest. City business units publishes their open data under version 1.0 of the Open Government License - Ontario. The legal agreement specifies that data re-users are free to, "copy, modify, publish, translate, adapt, distribute or otherwise use

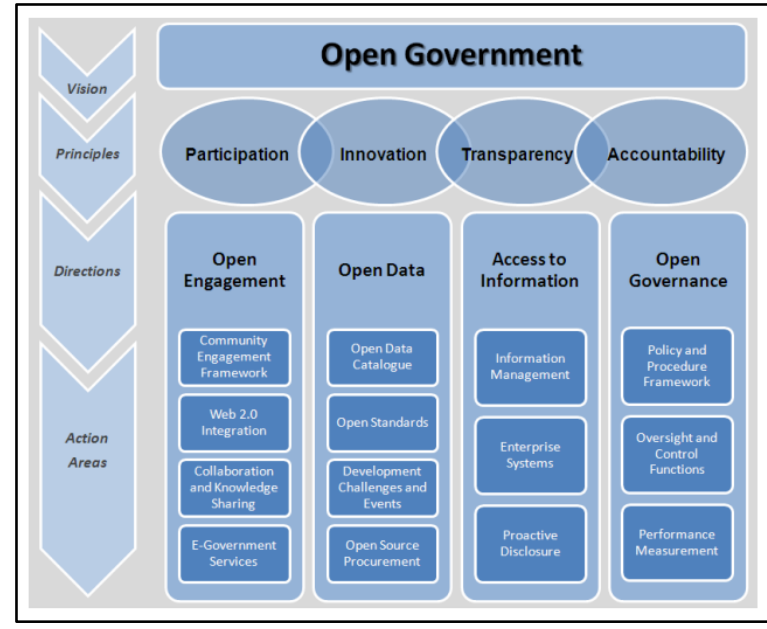

Figure 12 - City of Guelph's Open Government Framework (source: http://guelph.ca/wpcontent/uploads/GuelphOGF_Framewor k_Nov2012.pdf p.7)

\footnotetext{
123 IT Projects, Strategy and Digital at the City of Guelph. Interview with Rachel Bloom. Personal Interview. May $25^{\text {th }}, 2017$.

124 http://guelph.ca/plans-and-strategies/corporate-strategic-plan/service-modernization-program/\#

125 "An Open Meeting of Guelph City Council as Shareholder of Guelph Municipal Holding Inc.," Council Minutes. November 26, 2012. Guelph: ON. Accessed March 16, 2017. http://52.52.106.67/distiller/assets/pdf_files/943d0179c1236eb5e8a1d25cbc2e96ea.pdf.

126 "An Open Meeting of Guelph City Council as Shareholder of Guelph Municipal Holding Inc.," Council Minutes. November 26, 2012. Guelph: ON. Accessed March 16, 2017. http://52.52.106.67/distiller/assets/pdf_files/943d0179c1236eb5e8a1d25cbc2e96ea.pdf.

127 http://open.guelph.ca/open-data-guelph/
} 


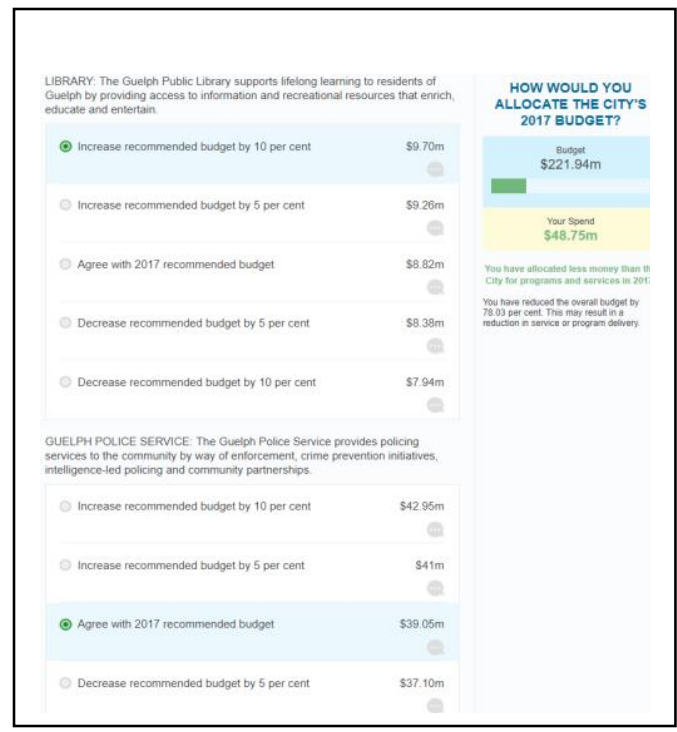

Figure 13 - Snapshot of Guelph's Budget Simulator Survey

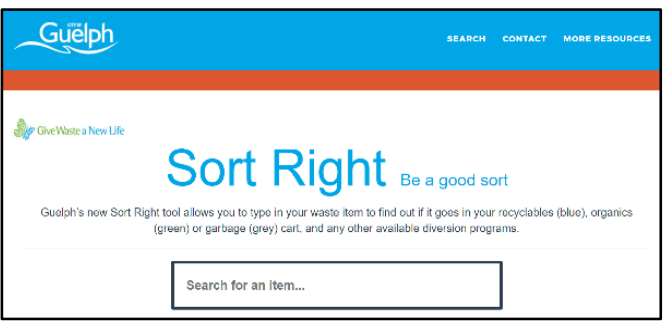

Figure 14 - Snapshot of Guelph's Sort Right Tool (source:

http://guelphapps.elasticbeanstalk.com/)

this information in any medium, mode, or format for any lawful purpose". ${ }^{128}$

Guelph repurposes their open data in a variety of civic oriented applications. For example, the city uses an open budget simulator to visualize budget information and decisions (see Figure 13). Other open data services include a map that geo-locates 311 data, an online fine payment system, an online tax payment system, and a waste sorting application (see Figure 14). ${ }^{129}$ In 2015, public officials hosted an open data hackathon to encourage the development of third party applications that benefit residents. In March of 2016, City Council awarded Open Guelph with $\$ 40,000$ CAD to build two new civic digital services.

\subsubsection{Citizen Engagement}

Information about the Open Guelph program is published on the city's website. ${ }^{130}$ The Open Guelph portal points to the Open Data Portal, the Open Government Action Plan, a government engagement platform, Open Guelph media and blogs, literature on open government and innovation, information about round tables and a City managed improvement network for citizens.

myGuelph, on the other hand, is a digital one-stop shop for residents to access City services. The city held extensive consultations and conducted a survey in early 2016 to solicit community feedback regarding which digital services would improve the lives of residents and services for businesses. ${ }^{131}$ As a result, myGuelph will implement a CRM system, service dashboards, interactive maps, tools for understanding council business, new digital public services, an online Q\&A about local government, an open information catalogue, and improved social media presence. ${ }^{132}$

The city's citizen engagement team will also consult to find out what residents consider a smart city to be. In addition, a random survey was distributed to 600 residents to assess if the city was

\footnotetext{
128 "City of Guelph Open Licence Agreement," Accessed March 15, 2017. http://data.open.guelph.ca/pages/opengovernment-licence.

${ }^{129}$ http://open.guelph.ca/2016/06/the-digital-services-you-said-would-make-your-life-easier-or-business-better/

130 "An Open Meeting of Guelph City Council as Shareholder of Guelph Municipal Holding Inc.," Council Minutes. November 26, 2012. Guelph: ON. Accessed March 16, 2017. http://52.52.106.67/distiller/assets/pdf_files/943d0179c1236eb5e8a1d25cbc2e96ea.pdf.

${ }^{131} \mathrm{http} / / /$ open.guelph.ca/open-government/myguelph/

132 "Project overview: myGuelph," Open Guelph. Accessed March 16, 2017. http://open.guelph.ca/wpcontent/uploads/2016/01/myGuelph-snapshot.pdf.
} 
meeting its Corporate Administration Plan goals. The survey asked questions about major urban issues, quality life in Guelph, perceptions of Guelph, overall satisfaction with municipal services and programs, and satisfaction with city staff. ${ }^{133}$ The output of this research informs Guelph's Community Plan. ${ }^{134}$

\subsubsection{Deployment of Geospatial and ICT Data}

The City of Guelph has a Corporate GIS Strategic Plan ${ }^{135}$ with a mission statement to "provide professional geospatial services to City of Guelph staff and citizens in order to enhance public services, improve operations, and to better disseminate information". ${ }^{136}$ Their Plan includes data standards; GIS functionality; public service and customer relations; GIS infrastructure; data creation, conversion, and maintenance; and coordination. ${ }^{137}$ This Plan specifies GIS software needs for each department and determines whether there is a desire by city staff to adopt GIS software. Examples of GIS software listed in the report are ArcGIS online, ArcGIS for desktop, Spatial Analyst, and a geocoding/data mining application.

Open data is part of Guelph's Corporate GIS Strategic Plan and the five-year tactical plan includes the implementation of open geospatial data standards. Guelph already openly publishes data about real-time transit bus services information via NextBus; NextBus uses the General Feed Transit Specification - Real Time, an open format to publish public transit data. The Corporate GIS Strategic Plan also discusses the Geospatial Content Management System (GeoCMS) and how it makes it easier for governments to openly publish geospatial data. GeoNode, for example is their web-based, open source application and platform which is an extendible and integrated way to publish data. The following is an excerpt from their GIS Strategic Plan:

"The City is currently in the process of standardizing on CKAN (Comprehensive Knowledge Archive Network) for the storage and distribution of data such as spreadsheets and the contents of databases. A logical next step would be to review existing GeoCMS packages and choose a system that will perform similar and management capabilities for spatial data in the enterprise GIS. The ability of the GeoCMS to easily publish spatial data makes it ideal for the Open Data initiative. Various GeoCMS packages exist

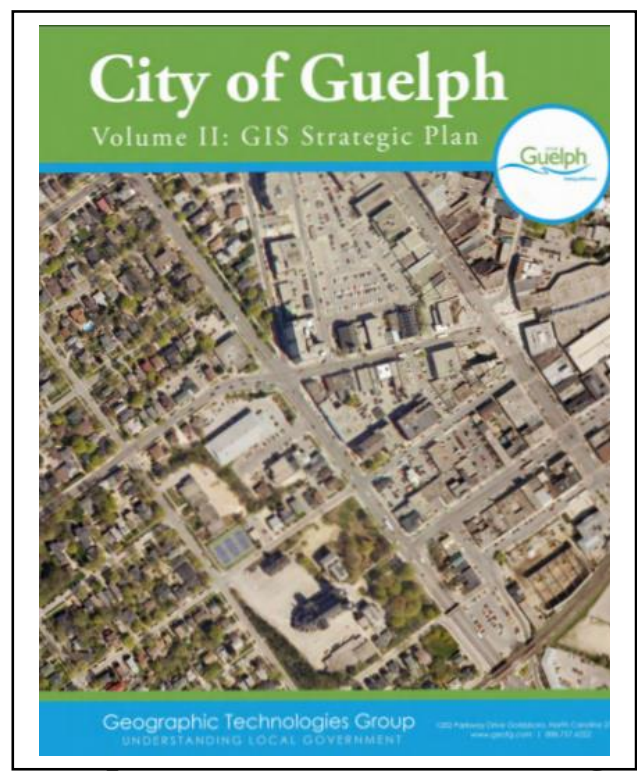

Plan (source:

https://guelph.ca/plans-andstrategies/corporate-gis-strategicplan/)

\footnotetext{
${ }^{133}$ http://guelph.ca/wp-content/uploads/council_agenda 102317.pdf\#page=4

134 https://guelph.ca/community-plan/

$135 \mathrm{http}: / /$ guelph.ca/plans-and-strategies/corporate-gis-strategic-plan/

136 “City of Guelph: Volume II: GIS Strategic Plan.” 2014. Geographic Technologies Group. Accessed April 3, 2017. http://guelph.ca/wp-content/uploads/GIS_Stratigic_Plan.pdf.

137 “City of Guelph: Volume II: GIS Strategic Plan.” 2014. Geographic Technologies Group. Accessed April 3, 2017. http://guelph.ca/wp-content/uploads/GIS_Stratigic_Plan.pdf.
} 
but one application worthy of note is GeoNode. GeoNode is an open source web-based application and platform for developing GIS and or deploying spatial data infrastructures (SDI). It is designed to be extended and modified and can be integrated into existing platforms such as ArcGIS. ",138

City staff currently use the KYUBIT ${ }^{139}$ program to do online analytical processing, including the tracking of key performance indicators and to populate its data dashboards. ${ }^{140}$ The software sits on top of the city's Microsoft data warehouse consisting of Microsoft SQL server databases. At the moment, all of the city's GIS databases sit within a data warehouse. However, the municipal IT Governance Committee is endorsing a plan to move all of the city's corporate databases into the same data warehouse so that internal data can be accessible across silos by using the KYUBIT program. The city as an organization is still determining the best way forward in terms of geocoding its city data and is consulting with its GIS software provider, ESRI. The city envisions having a location identifier associated with each of its datasets. In addition, the city organization is assessing how best to optimize data access from visualizations. Currently, the business units use ESRI's ArcGIS online service to map data so that authorized persons from multiple departments can access geo-visualized information.

Currently, the city retains all its data for preservation purposes for an indefinite period of time. The Records and Information Management Subcommittee, a part of the IT Governance

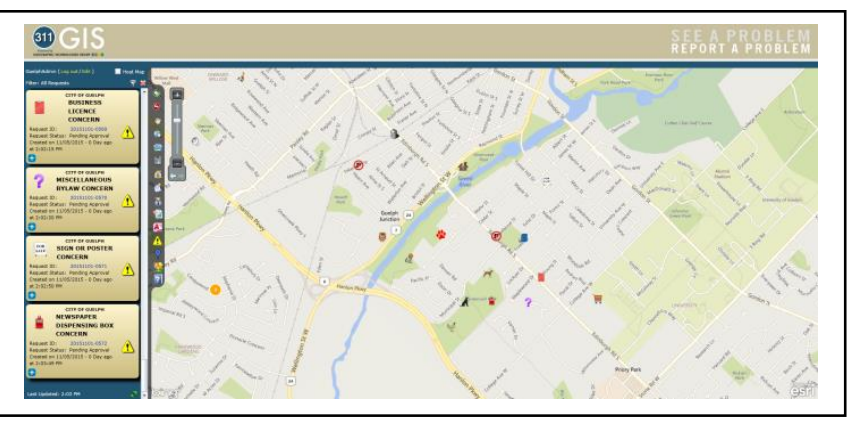

Figure 16 - Snapshot of City of Guelph's Service Request Map (source:

https://guelph.ca/how-can-we-help-you/map-

\section{app/)} Committee, will, as part of their work plan, create a retention policy for all City owned data.

Like Edmonton, Guelph hosts an array of geospatial information on their open data portal. Guelph's open data catalogue publishes geospatial data in both open, machine-readable formats (e.g. KML and GeoJSON) and proprietary, machinereadable formats (e.g. ESRI shapefile). In addition, the city has an interactive online mapping system ${ }^{141}$ and also offers a park

\footnotetext{
${ }^{138}$ http://guelph.ca/plans-and-strategies/corporate-gis-strategic-plan/

${ }^{139}$ kyubit.com

${ }^{140} \mathrm{http} / /$ guelph.ca/city-hall/city-administrators-office/strategic-planning-corporate-initiatives/publicreporting/performance-dashboard/

${ }^{141} \mathrm{http} / /$ guelph.ca/living/getting-around/maps/
} 
locator, grass maintenance tracker, and a 311 Map online.

\subsubsection{Summary and Observations}

The City of Guelph does not have an official smart city strategy, but it does have smart city-like initiatives and plans (see Table 3 ) and has articulated their vision for the smart city in its Corporate Technology Strategic Plan. ${ }^{142}$

Even in the absence of a smart city strategy, Guelph is well on its way to becoming an open smart city (see Table 4 below). Guelph is particularly notable for the centralization of digital services, the integration of key data intensive units across the municipality, citizen engagement practices, and innovative procurement that includes open source, GIS strategy/needs assessment, and its practices for specifying data Intellectual Property (IP). The City of Guelph is also guided by a set of principles and unique partnerships (e.g., SmartGrid Cooperative) to inform its transition towards a more environmentally conscious city. Furthermore, the government actively engages with its residents on urban issues and intends to consult them about what they would like to see in a smart city, although how recommendations will be integrated in practice remains a work in progress.

Table 4 - Summary of the City of Guelph Smart City Plans

\begin{tabular}{|c|l|c|}
\hline $\begin{array}{c}\text { Smart City } \\
\text { Component/Process }\end{array}$ & \multicolumn{1}{|c|}{ Current State } & $\begin{array}{c}\text { Considerations for the } \\
\text { Future }\end{array}$ \\
\hline $\begin{array}{c}\text { Smart City } \\
\text { Strategy }\end{array}$ & $\begin{array}{l}\text { Not yet; But Guelph does have } \\
\text { smart city plans articulated in its } \\
\text { Corporate Technology Strategic } \\
\text { Plan. }\end{array}$ & - \\
\hline $\begin{array}{c}\text { Smart City } \\
\text { Roadmap \& } \\
\text { Guiding Principles }\end{array}$ & Not yet. & -- \\
\hline & $\begin{array}{l}\text { Not yet; But smart city projects are } \\
\text { integrated in some departmental } \\
\text { strategic plans }\end{array}$ & $\begin{array}{c}\text { Worporate Administrative } \\
\text { Plan mandate and } \\
\text { interoperate smart city } \\
\text { components? }\end{array}$ \\
\hline Urban Plan & $\begin{array}{l}\text { Even in the absence of an official } \\
\text { smart city strategy, there is a Digital } \\
\text { Group and IT Governance } \\
\text { Committee that will be responsible } \\
\text { for smart city/digital operations. }\end{array}$ & $\begin{array}{c}\text { How will residents and civic } \\
\text { technology organizations be } \\
\text { incorportated into the } \\
\text { governace structure? }\end{array}$ \\
\hline $\begin{array}{c}\text { Governance } \\
\text { Structure }\end{array}$ & $\begin{array}{c}\text { Will there be dedicated } \\
\text { legal, privacy and security } \\
\text { personnel/function? }\end{array}$ \\
\hline $\begin{array}{c}\text { Dedicated } \\
\text { Personnel }\end{array}$ & Not yet. & \\
\hline
\end{tabular}

${ }^{142}$ http://guelph.ca/wp-content/uploads/CorporateTechnologyStrategicPlan.pdf 


\begin{tabular}{|c|c|c|}
\hline Dedicated Unit & $\begin{array}{l}\text { Not yet; A Digital Team is being } \\
\text { developed, although they will not } \\
\text { be FTEs on smart city or digital } \\
\text { initiatives. }\end{array}$ & $\begin{array}{l}\text { Will there be dedicated } \\
\text { legal, privacy and security } \\
\text { personnel/function? }\end{array}$ \\
\hline $\begin{array}{l}\text { Inventory of } \\
\text { initiatives }\end{array}$ & $\begin{array}{l}\text { Not yet; But several smart city-like } \\
\text { projects have been identified and } \\
\text { are ongoing. }\end{array}$ & $\begin{array}{l}\text { How will City of Guelph } \\
\text { strategize downstream } \\
\text { benefits of smart city } \\
\text { initatives? }\end{array}$ \\
\hline Procurement & $\begin{array}{l}\text { Not explicitly; But exploring the } \\
\text { implementation of a flexible system } \\
\text { via an accelerator program, open } \\
\text { source procurement and the } \\
\text { consideration of data IP at the } \\
\text { contractual level. }\end{array}$ & $\begin{array}{l}\text { What will the guiding } \\
\text { principles, standards, open } \\
\text { source, and etc., be for } \\
\text { procuring smart city } \\
\text { technologies? Will terms } \\
\text { such as open source, privacy } \\
\text { and transparency by design, } \\
\text { and cybersecurity standards } \\
\text { guide requests for tenders } \\
\text { (RFTs)? Will the city } \\
\text { continue to retain data, } \\
\text { hardware and software IP as } \\
\text { they partner with technolgoy } \\
\text { firms? }\end{array}$ \\
\hline Engagement & $\begin{array}{l}\text { Not yet; But engagement is part of } \\
\text { open data and open government } \\
\text { programs and the public has been, } \\
\text { and will continue to be, surveyed on } \\
\text { technology plans. }\end{array}$ & $\begin{array}{l}\text { How will residents be } \\
\text { empowered and included in } \\
\text { decision making throughout } \\
\text { project life cycles and in the } \\
\text { long term? }\end{array}$ \\
\hline Openness & $\begin{array}{l}\text { Not yet; But there is an open data } \\
\text { catalogue that implements open } \\
\text { formats, open maps, consideration } \\
\text { of an open source strategy, open } \\
\text { license, CKAN platform and open } \\
\text { data hackathons; Guelph engages } \\
\text { citizens on things like their CRM } \\
\text { and conducts surveys about } \\
\text { technology decisions. }\end{array}$ & $\begin{array}{l}\text { Will comittment to open } \\
\text { data, open standards, and } \\
\text { personal privacy be upheld } \\
\text { when procuring smart city } \\
\text { technologies? }\end{array}$ \\
\hline Spatial Data & $\begin{array}{l}\text { Not yet; But Guelph has a mature } \\
\text { GIS program with a Corporate GIS } \\
\text { Strategy, and part of its vision is } \\
\text { geo-enabling its open data assets. }\end{array}$ & $\begin{array}{l}\text { How will Guelph ultimately } \\
\text { decide on the adoption of } \\
\text { standards for integrating } \\
\text { geospatial data? }\end{array}$ \\
\hline Crowdsourcing & $\begin{array}{l}\text { Not yet; But the city has its service } \\
\text { requests map online. }\end{array}$ & $\begin{array}{c}\text { How are crowdsourced data } \\
\text { or citizen science intiatives } \\
\text { being utilized for the smart } \\
\text { city? }\end{array}$ \\
\hline
\end{tabular}




\begin{tabular}{|c|l|c|}
\hline $\begin{array}{c}\text { Standards \& } \\
\text { Interoperability }\end{array}$ & $\begin{array}{l}\text { Not specified for the smart city; } \\
\text { Data standards and open source are } \\
\text { considered in the GIS Strategic } \\
\text { Plans. }\end{array}$ & $\begin{array}{c}\text { Will interoperabiliy of } \\
\text { software and data be } \\
\text { specified? Will the smart } \\
\text { city be a platform that others } \\
\text { plug into? }\end{array}$ \\
\hline Privacy & $\begin{array}{l}\text { The city abides by Ontario's } \\
\text { Municipal Freedom of Information } \\
\text { and Protection of Privacy Act } \\
\text { (MFIPPA). }\end{array}$ & $\begin{array}{c}\text { Will privacy by design } \\
\text { principles be applied for } \\
\text { smart city technologies? }\end{array}$ \\
\hline Security & $\begin{array}{l}\text { The Guelph IT Governance } \\
\text { Committee has a security and } \\
\text { physical security subcommittee. }\end{array}$ & $\begin{array}{l}\text { What security standards and } \\
\text { practices will be applied in a } \\
\text { smart city context, such as } \\
\text { for data captured by meters } \\
\text { and sensors and at the device } \\
\text { level? }\end{array}$ \\
\hline Archiving & $\begin{array}{l}\text { The city has commissioned a report } \\
\text { for recommendations to address } \\
\text { identified gaps/risks and has a } \\
\text { Records and Information } \\
\text { Management (RIM) Strategy that } \\
\text { mentions management of new and } \\
\text { emerging technologies; A data } \\
\text { retention strategy is under } \\
\text { development. }\end{array}$ & $\begin{array}{c}\text { How will strategic data } \\
\text { preservation account for } \\
\text { emergent smart city } \\
\text { technologies, especially IoT } \\
\text { and SaaS? }\end{array}$ \\
\hline
\end{tabular}




\subsection{La Ville de Montréal}

La Ville de Montréal is located on the Île de Montréal at the confluence of the Saint Lawrence and Ottawa Rivers in the province of Quebec and on the traditional and unceded territory of the Kanien'keha:ka First Nation. The city was incorporated in 1832 and is Canada's second-most populous city. According to Statistics Canada, ${ }^{143}$ la Ville de Montréal had a reported population of 1,704,694 people and has a land area of 265.65 square kilometers. 1,680,910 people in Montréal speak the city's official language, French, as their first language. ${ }^{144}$ Montréal is considered to be a center for the expression and diffusion of French Canadian culture and is also host to several multicultural communities and neighborhoods.

Montréal's City Council consists of 65 members that represent the city's distinct municipal boroughs and is led by a Mayor, who is the head of the executive branch. Montréal's Executive Committee manages contracts and grants, human and capital resources, buildings, and supplies. In 2013, la Ville de Montréal published an update to its Development Plan ${ }^{145}$ that outlines development principles (e.g., community involved in drawing up and implementing the plan, development of public transit and active transportation, values of solidarity and inclusiveness, and social diversity).

City boroughs each have their own Mayor and a Borough Council and are distinct in how they manage their jurisdictions. Boroughs administer budgets and services, such as the cleanliness of public places, maintenance, municipal road repair, distribution of drinking water, sports and cultural activities, local parks, social development and urban planning.

The city is promoted widely as a leader in aeronautics, information technology, artificial intelligence, biotechnology, medicine, multimedia, the arts, and urban planning. ${ }^{146}$ It is a university center due to its two French and two English speaking universities. Montréal acts as a cultural and economic metropolis for Québec that is at the heart of a greater region of more than three million people. ${ }^{147}$

\subsubsection{Strategy}

La Ville de Montréal published its 2014-2017 Montréal Smart and Digital City Strategy under the leadership of former Mayor of Montréal, Denis Codèrre. A smart city vision was a part of his election strategy during the 2013 municipal election.

According to their smart city vision, Montréal intends to become an international leader among smart cities by 2017 . This vision is guided by the following four focus areas developed by

\footnotetext{
${ }^{143}$ http://www12.statcan.gc.ca/census-recensement/2016/dppd/prof/details/page.cfm?Lang=E\&Geo1=CSD\&Code1=2466023\&Geo2=PR\&Code2=01\&Data=Count\&SearchTex $\mathrm{t}=$ Montréal\&SearchType=Begins $\&$ SearchPR $=01 \& \mathrm{~B} 1=\mathrm{All} \& \mathrm{TABID}=1$

${ }^{144} \mathrm{http}: / / \mathrm{www} 12$. statcan.gc.ca/census-recensement/2016/dp$\mathrm{pd} /$ prof/details/page.cfm?Lang=E\&Geo1=CSD $\&$ Code $1=2466023 \&$ Geo2=PR \&Code2=01\&Data=Count $\&$ SearchTex $\mathrm{t}=$ Montréal\&SearchType $=$ Begins $\&$ SearchPR $=01 \& \mathrm{~B} 1=\mathrm{All} \& \mathrm{TABID}=1$

${ }^{145}$ http://ville.Montréal.qc.ca/portal/page?_pageid=7737,98695583\&_dad=portal\&_schema=PORTAL

146 Official Tourist Guide 2017. Tourisme Montréal. Modified in 2017. https://indd.adobe.com/view/b679d129-4b124ca3-a6d3-8c84173480ae.

147 http://ville.Montréal.qc.ca/portal/page?_pageid=2762,3099669\&_dad=portal\&_schema=PORTAL
} 
Montréal's elected officials: collection, communication, collaboration, and coordination. Each focus area is described in Table 5 below, along with related initiatives. The former Mayor's administration later established the Bureau de la Ville Intelligente et Numerique (BVIN) as the responsible institution tasked with defining Montréal's smart city strategy, designating strategic initiatives and formulating funding/partnerships to implement projects.

Table 5 - Focus Areas of Smart and Digital City Vision

\begin{tabular}{|c|c|c|}
\hline Focus Area & $\begin{array}{c}\text { Descriptive } \\
\text { Characteristics }\end{array}$ & Supportive Initiatives \\
\hline \multirow[b]{2}{*}{ Collection } & \multirow{2}{*}{$\begin{array}{l}\text { Transparent } \\
\text { management and } \\
\text { open government }\end{array}$} & $\begin{array}{l}\text { Releasing bulk data and developing applications, } \\
\text { enabling users to display and use the data. }\end{array}$ \\
\hline & & $\begin{array}{l}\text { Collecting and analyzing telemetry data to boost } \\
\text { control over, and optimize, the use of public } \\
\text { resources. }\end{array}$ \\
\hline \multirow{3}{*}{ Communication } & \multirow{3}{*}{$\begin{array}{l}\text { Information access } \\
\text { and distribution } \\
\text { systems }\end{array}$} & $\begin{array}{l}\text { Developing a Web platform and mobile apps to } \\
\text { distribute information to citizens in real-time. }\end{array}$ \\
\hline & & Deploying a wired and Wi-Fi broadband network. \\
\hline & & $\begin{array}{l}\text { Creating new technology learning and creation } \\
\text { centres. }\end{array}$ \\
\hline \multirow{2}{*}{ Coordination } & \multirow{2}{*}{$\begin{array}{l}\text { Digital public } \\
\text { services }\end{array}$} & $\begin{array}{l}\text { Developing smart transport, infrastructure, security, } \\
\text { energy, water and environmental management } \\
\text { systems. }\end{array}$ \\
\hline & & $\begin{array}{l}\text { Providing digital, while preserving conventional, } \\
\text { access to public services ( } 311 \text {, permit issuance, } \\
\text { etc.). }\end{array}$ \\
\hline \multirow{3}{*}{ Collaboration } & \multirow{3}{*}{$\begin{array}{l}\text { Supporting industry } \\
\text { to stimulate } \\
\text { innovation and } \\
\text { creativity }\end{array}$} & $\begin{array}{l}\text { Helping private and institutional stakeholder set up } \\
\text { networks of technology incubators and accelerators. }\end{array}$ \\
\hline & & Addressing the needs of technology start-ups. \\
\hline & & $\begin{array}{l}\text { Encouraging the use of the public space to test } \\
\text { innovative solution to solve municipal issues. }\end{array}$ \\
\hline
\end{tabular}

The strategy has identified a number of smart city models, such as an IT-based model, a big databased model, and an organic city living model. These definitions are based on the UK Department for Business, Innovation \& Skills' (BIS) Smart City Framework (2014) ${ }^{148}$ and the European Innovation Partnership on Smart Cities and Communities' Strategic Implementation Plan (2013). ${ }^{149}$ According to the Strategy, a smart city is about "better services for citizens, a universally

\footnotetext{
148 "A smart city is one where there is the effective integration of physical, digital and human systems in the built environment to deliver a sustainable, prosperous and inclusive future for its citizens."

149 "Smart cities should be regarded as systems of people interacting with and using flows of energy, materials, services and financing to catalyze sustainable economic development, resilience, and high quality of life; these flows and interactions become smart through making strategic use of information and communication
} 
higher standard of living and the harnessing of our metropolis's resources to ensure its development is in line with the needs of the city's people". ${ }^{150}$

The Montréal Smart and Digital City Strategy and its priorities emerged from direct consultations with the community. Several phone and web surveys were conducted between 2012 and 2014, along with an analysis of 311 requests, numerous town hall meetings and suggestions from citizens, ideas dropped into the BVIN's online suggestion box, and the jevoismtl.com initiative. ${ }^{151}$ Results of these consultations led to the following priority areas: urban mobility, direct services to citizens, way of life, democratic life, and economic development (see Figure 17).

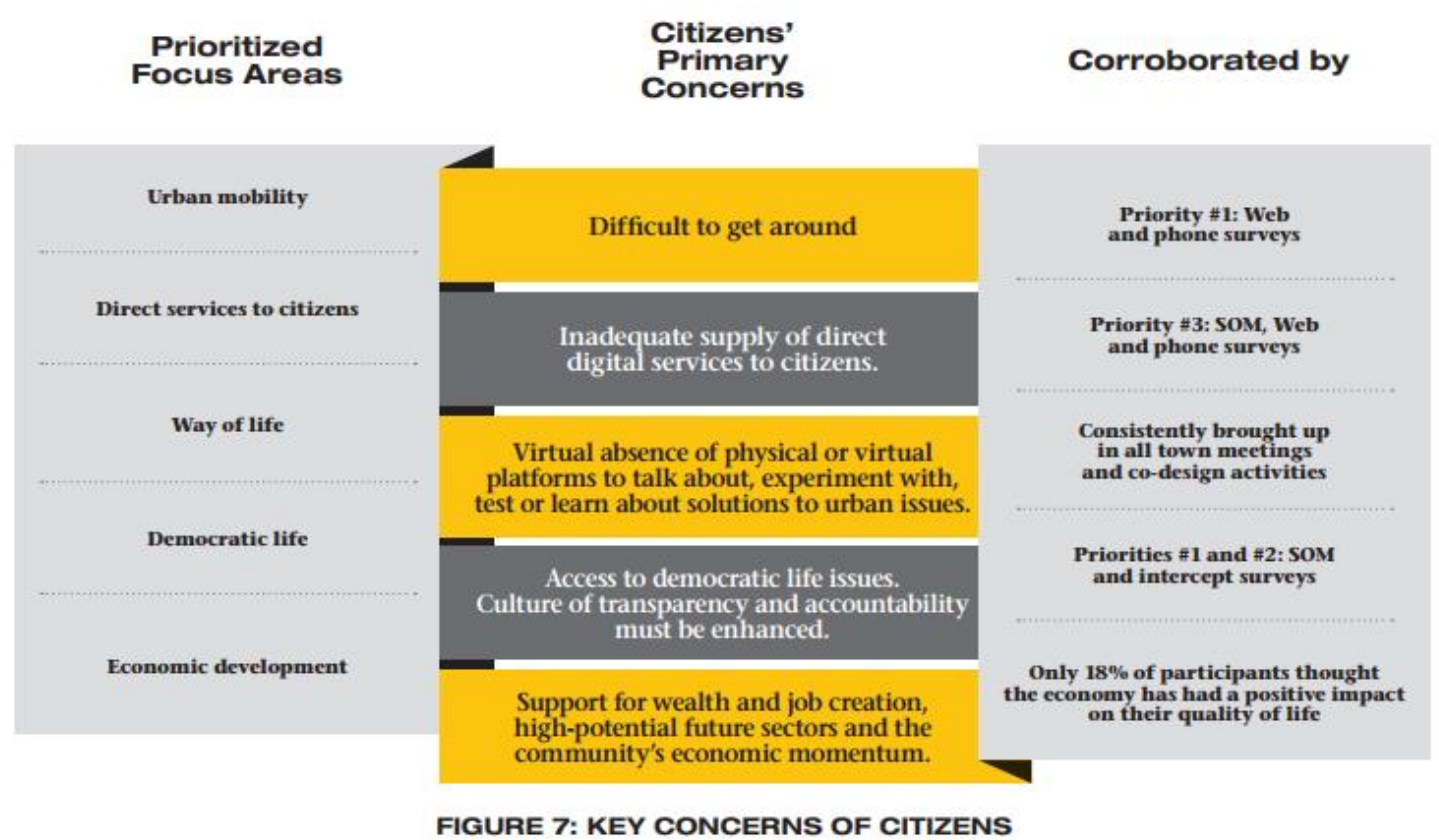

\section{Figure 17- Citizen Concerns and Prioritized Focus Areas (Source: Montréal Smart and Digital City Strategy (2014-2017) p. 32)}

The BVIN then consulted Think Tanks, such as the Intelligent Communities Forum (ICF), and almost 200 experts to help them co-design the program's structure. Research to formulate the strategy included a review of international smart city case studies for the cities of Arlington (USA), Barcelona (Spain), Columbus (USA), Eindhoven (Netherlands), Lyon (France), New York (USA), and Toronto (Canada), all of which are listed on the BVIN website along with numerous other references. ${ }^{152}$ In addition, the BVIN website cites strategic smart city reports commissioned by the

\footnotetext{
infrastructure and services in a process of transparent urban planning and management that is responsive to the social and economic needs of society."

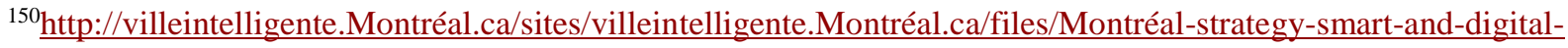
city-an.pdf

${ }^{151}$ See Section 3.3.5.1 for more information about jevoismtl.com initiative.

152 http://villeintelligente.Montréal.ca/en/documents
} 
European Commission and standards bodies (e.g., British Standards Institution and International Telecommunication Union). ${ }^{153}$

After considering resident consultations and international best practices research, the BVIN created a strategic framework that aligns their smart city with the following 9 policy guidelines:

1. Developing multiservice ultra-high-speed telecom infrastructure

2. Releasing, analyzing and using prioritized open data

3. Creating an open interoperable technological architecture

4. Developing solutions to urban issues in co-creation with the community

5. Optimizing the mobility of people across the island in real time

6. Increasing the provision of direct digital services to citizens and businesses

7. Supporting urban innovation and diminishing the digital divide

8. Improving access to democratic life and bolstering the culture of transparency and accountability

9. Promoting the growth of a leading-edge sector by employing the smart city strategy as a catalyst to bring the smart city to fruition and as an engine of economic development

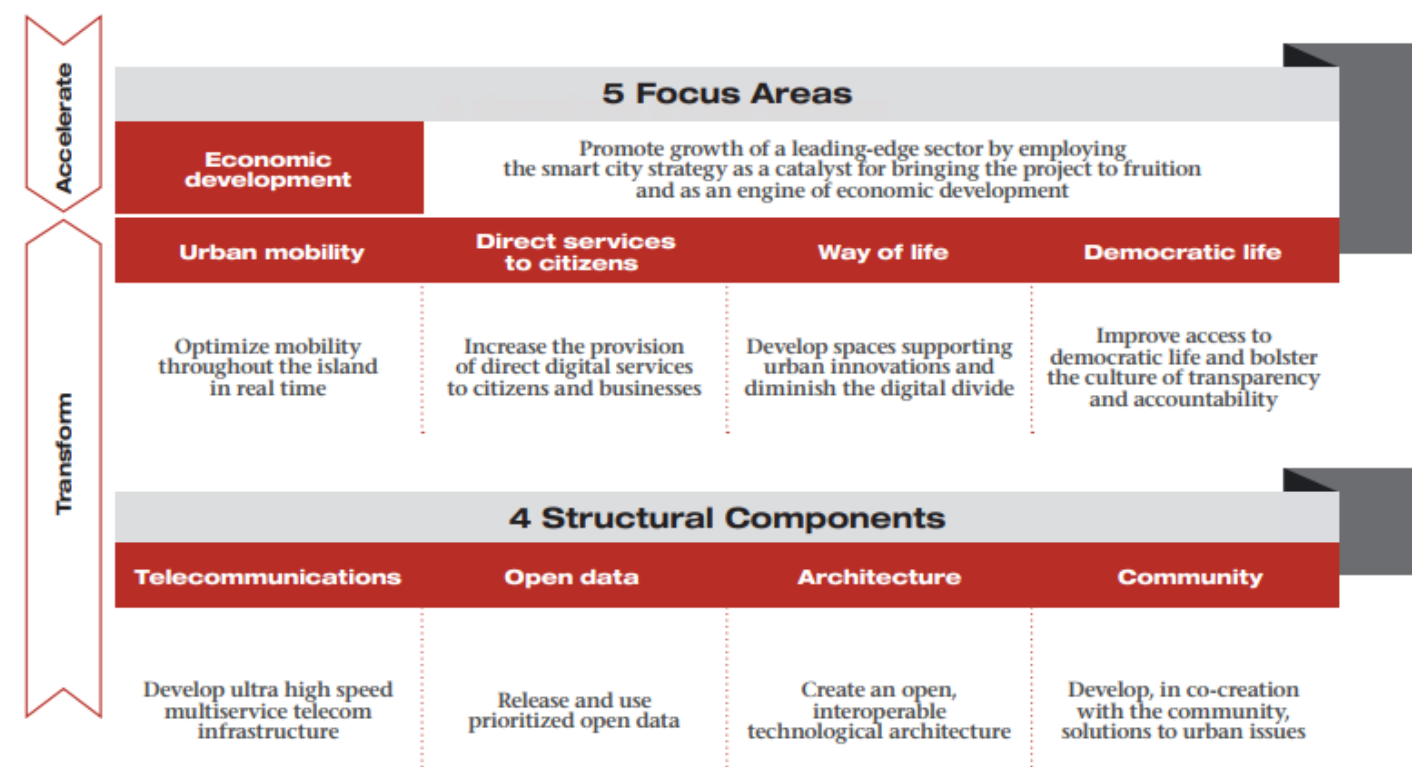

Figure 18 - Summary of Policy Guidelines for Montréal's Smart City (Source: Montréal Smart and Digital City Action Plan (2015-2017) p. 4)

La Ville de Montréal later published the Montréal Smart and Digital City Action Plan 20152017. ${ }^{155}$ It contains information about the consultation, strategy, plan, implementation, and the follow-up of 70 smart city projects that span six smart city programs.

${ }^{153}$ http://villeintelligente.montreal.ca/en/documents 


\subsubsection{Perceived Beneficiaries}

Smart city representatives believe citizens will benefit from projects that focus on addressing urban issues, and government will save costs via the strategy's projects. Public officials, however, are still working on how to communicate tangible outcomes to smart city beneficiaries. ${ }^{154}$

Then BVIN also has attempted to ensure that Montréal's smart city will benefit people with disabilities and has requested proposals for software solutions at an event hosted by Desjardin. In addition, the BVIN has engaged in ongoing conversations with a team that aims to provide better services to people with disabilities. Furthermore, it is currently working on a project to crowdsource information about accessibility around the city.

\subsubsection{Action Plan Components}

The Montréal Smart and Digital City Action Plan details 70 projects that arose from public consultations and research on smart city best practices. The six overarching smart city programs are: (1) public WiFi, (2) ultra-high speed multiservice network, (3) smart city economic cluster, (4) smart mobility, (5) participatory democracy, and (6) digital public services, ${ }^{155}$ as seen in Table 6 below.

Table 6 - List of Smart City Programs and Examples of Projects for la Ville de Montréal

\begin{tabular}{|c|l|}
\hline Smart City Program & \multicolumn{1}{c|}{ Examples of Projects } \\
\hline Public WiFi & $\begin{array}{l}\text { Deployment in indoor municipal facilities, urban areas, commercial } \\
\text { corridors, target neighborhoods; mobile hot spots; WiFi locator app. }\end{array}$ \\
\hline $\begin{array}{c}\text { Ultra-High-Speed } \\
\text { Multiservice Network }\end{array}$ & $\begin{array}{l}\text { New telecom policy; one-stop-shop - urban telecommunications; } \\
\text { deployment of fibre to the home. }\end{array}$ \\
\hline $\begin{array}{c}\text { Smart City Economic } \\
\text { Cluster }\end{array}$ & $\begin{array}{l}\text { Montréal innovation challenges; employee innovation challenges; } \\
\text { Smart City accelerator; Smart City investment fund; living labs in } \\
\text { libraries and other venues; digital workshops and fab labs in } \\
\text { libraries; innovation PME program - Smart City initiative; } \\
\text { Montréal open data portal. }\end{array}$ \\
\hline $\begin{array}{c}\text { Smart Mobility } \\
\text { Participatory } \\
\text { Democracy }\end{array}$ & $\begin{array}{l}\text { Inventory of mobility data in real time; collection of incomplete and } \\
\text { missing data; iBUS, GeoTraffic; Open Montréal 511 API; smart } \\
\text { taxi; integrated travel corridor management (CGMU); traffic light } \\
\text { synchronization; smart parking application. }\end{array}$ \\
\hline $\begin{array}{l}\text { Reformulation of open data policy; Montréal's open data portal; } \\
\text { automated data retrieval via application program interfaces (APIs); } \\
\text { visualization of open contract data using the Open Contracts data }\end{array}$ \\
\hline
\end{tabular}

154 BVIN at la Ville de Montréal. Personal interview with Rachel Bloom. May 24 ${ }^{\text {th }}, 2017$.

155"Montréal Smart and Digital City: 2015-2017 Action Plan," Last modified May, 2015.

http://villeintelligente.Montréal.ca/sites/villeintelligente.Montréal.ca/files/plan-action-bvin-ce-6-mai-2015-eng.pdf. 


\begin{tabular}{|l|l|}
\hline & $\begin{array}{l}\text { standard; open budget data visualization; public safety data } \\
\text { visualization; online right of initiative (e-petition). }\end{array}$ \\
\hline Digital Public Services & $\begin{array}{l}\text { Pedestrian information terminals; digital citizenship and literacy } \\
\text { initiatives; online/mobile payment functionalities; digital citizen } \\
\text { identity; online OPUS recharge; info-snow application; info-towing } \\
\text { application; municipal court online. }\end{array}$ \\
\hline
\end{tabular}

The Montréal Smart and Digital City Action Plan (2015-2017) also lists the entities that are in charge of each smart city project, the role of the BVIN, how projects are doing, and how those projects relate to Montréal's Smart and Digital City Strategy (2014-2017), timelines, and the entities that are providing financial support.

\subsubsection{Smart Mobility}

As stated previously, smart mobility is a key focus area of the Montréal Smart and Digital City Strategy. The Montréal Smart and Digital City Action Plan (2015-2017) includes information about the Centre de gestion de la mobilite urbaine (CGMU), which is the central point of Montréal's intelligent transportation systems (ITS). ${ }^{156}$ Montréal's Strategic ITS Plan ${ }^{157}$ includes a control center, messaging system, management of traffic signals, electronic payment systems, and linking to mobile applications and smart phones. The CGMU's control center, equipped with servers, software, and video screens, processes and analyzes real time information and relies on telecommunications to integrate and assure the transmission of data. A dedicated fiber network connects equipment (sensors, variable message signs, traffic lights) to the CGMU. ${ }^{158}$ The network enables the control center to know about the state of the equipment, to communicate with the equipment in the field, and to collect data remotely.

In addition, more than 500 observation cameras have been installed around the city and are linked to the CGMU. ${ }^{157}$ The CGMU creates geo-visualizations of data to ensure that partners can readily access and understand mobility information in real time. ${ }^{159}$ The initiative relies on a partnership with la Ville de Montréal, the Police Service, the Société de transport de Montréal (STM), the Montréal Public Safety Center, Montréal Parking Center, Quebec Ministry of Transportation and

156 "Les systèmes de transport intelligents: Au service des citoyens" http://ville.Montréal.qc.ca/pls/portal/docs/PAGE/TRANSPORTS_FR/MEDIA/DOCUMENTS/STI\%20BROCHUR E-V3.PDF.

157 "Center for Urban Mobility Management (CGMU)," Banque d'information 311. Last modified September 27, 2016. http://www1.ville.Montréal.qc.ca/banque311/content/centre-de-gestion-de-la-mobilit\%C3\%A9-urbaine-cgmu. 158 "Les systèmes de transport intelligents: Au service des citoyens", la Ville de Montréal. Accessed March 24, 2017. http://ville.Montréal.qc.ca/pls/portal/docs/PAGE/TRANSPORTS_FR/MEDIA/DOCUMENTS/STI\%20BROCHUR E-V3.PDF.

159 "Les systèmes de transport intelligents: Au service des citoyens", Ville du Montréal. Accessed March 24, 2017. http://ville.Montréal.qc.ca/pls/portal/docs/PAGE/TRANSPORTS_FR/MEDIA/DOCUMENTS/STI\%20BROCHUR E-V3.PDF. 
the Federal Bridge Corporation. The city also publishes non-personal real-time traffic information, provided by the CGMU, to its open data catalogue online (see Section 3.2 to learn more). ${ }^{160}$

\subsubsection{Recognition}

Montréal is internationally recognized for its smart city efforts. The ICF awarded the Montréal with the Smart Community of the Year award in 2016. ${ }^{161}$ The ICF analyzes quantitative data, does site inspections, and collects votes from an international jury of international experts to select award recipients. The ICF assesses cities according to the following six criteria: broadband, knowledge workforce, innovation, digital equality, sustainability, and advocacy. ${ }^{162}$ Specifics on how it measures these criteria are not made available publicly.

\subsubsection{Governance}

The muncipal Executive Committee appoints a member responsible for the smart city. The BVIN is situated directly under Montréal's General Manager and Executive Committee. The BVIN is aligned with the muncipal central services and is responsible for piloting and governing the projects listed in the Montréal Smart and Digital City Action Plan, and individuals at City departments operationalize these projects. The BVIN's role is to support, facilitate, and follow up with the departments and there is no overarching and interdepartmental decision-making committee or commission that makes decisions about the smart city.

The IT department conducts privacy and security assessments and provides input about privacy considerations during the planning stages of smart city technological initiatives. Some older IT systems have required an ex-post privacy assessment of data. In addition, the City Clerk ensures that personal privacy is not violated by a department openly publishing data.

\subsubsection{Procurement}

The Montréal Smart and Digital City Action Plan supports the development of Montréal's startup technology industry. La Ville de Montréal funds a venture capital firm, Capital Intelligent Montréal, which provides financial support to innovative companies working on urban solutions. In addition, la Ville de Montréal is a partner of Canada's first smart city accelerator, InnoCité MTL. The accelerator provides training and opportunities for startups to test products with the government and partners. InnoCité MTL is a part of LaMain, which coordinates the activities of accelerator programs and incubators in Quebec.

Requests for Tenders (RFTs) by the municipality often include specific requirements that do not easily align with existing software services. Montréal's smart city accelerator, InnoCité, addresses this issue by making the software lightweight and by implementing a Software as a Service (SaaS) model. While these solutions are innovative, the city organization is still working out how to

\footnotetext{
${ }^{160} \mathrm{http}: / /$ donnees.ville.Montréal.qc.ca/dataset/circulation-mobilite-temps-reel

${ }^{161}$ Bell, Robert and Goyette, Stephane. Intelligent Community Montréal: Human, Open, and Innovative. Montréal: ICF, 2016. Accessed March 15, 2017. http://villeintelligente.Montréal.ca/sites/villeintelligente.Montréal.ca/files/icftop7-Montréal-visit-report.pdf.

162 Bell, Robert and Goyette, Stephane. Intelligent Community Montréal: Human, Open, and Innovative. Montréal: ICF, 2016. Accessed March 15, 2017. http://villeintelligente.Montréal.ca/sites/villeintelligente.Montréal.ca/files/icftop7-Montréal-visit-report.pdf.
} 
negotiate conditions in user agreements to enable municipal staff to exert complete control over the data generated by outsourced systems and to ensure that these can be archived for the future.

Montréal is also working to change requirements in building permit contracts, which will require that builders disclose detailed data related to traffic construction and closures. Disclosing detailed geospatial information about traffic closures and construction helps city government improve mobility, which is a key goal set forth by the Montréal Smart and Digital City Strategy.

Central IT's call for tender template does not standardize language about access to data, formats, standards, and privacy. Instead, each borough determines what is in their best interest and they structure their own RFT templates. The budget for the smart city projects is decentralized and sources of funding for projects are specified in the smart city action plan.

\subsubsection{Openness}

Like Edmonton, la Ville de Montréal's open data program is subsumed within their smart city strategy. Montréal's Registry is responsible for applying the Province's Act Respecting Access to Documents Held by Public Bodies and the Protection of Personal Information, and recommends that data be made available according to the Open Data Policy's specified principles. Montréal's Open Data Policy ${ }^{163}$ documents the policy's objective; scope; definitions; guiding principles regarding data access; data inventory and its exceptions; supporting documents; access to information and proactive disclosure; responsibility for applying the policy; and its implementation date. The Policy's scope applies to Montréal's administrative units, including boroughs. Transparency and data quality principles resemble the principles promoted by the Sunlight Foundation. Open data provisions therefore adhere to the data quality standards of completeness, primacy, timeliness, ease of physical and electronic access, machine readability, non-discrimination, use of commonly owned (open) standard formats, (open) licensing, permanence, and usage costs. In addition, the Policy advocates for an open by default approach for publishing public datasets. Government must also justify the reasoning (i.e., commercial, privacy-related, etc.) for withholding datasets from the public.

Montréal's Open Data Policy is outlined in their Portail Données Ouvertes (Open Data Portal). The portal contains an open data catalogue hosted on the CKAN platform, which is an open source platform to publish city data online. Montréal's Portail Données Ouvertes stores metadata about the catalogues datasets in its webpage. The open data portal enables the public to suggest datasets for local government to publish and provides information about licensing. The legal agreement specifies that the data are free to use and can be re-purposed for any lawful purpose. In addition, la Ville de Montréal has visualizations of open data about procurement contracts and crime. ${ }^{164}$ The procurement data are visualized according to the Open Contracting Data Standard and anyone may query the data about public contracts by using an open API. ${ }^{165}$

The Open Data Policy does not define openness for a municipality more generally. According to city staff at the BVIN, an open city refers to transparency and accountability by the government

\footnotetext{
${ }^{163} \mathrm{http}: / /$ donnees.ville.Montréal.qc.ca/portail/city-of-Montréal-open-data-policy/

$164 \mathrm{https} / / /$ ville.Montréal.qc.ca/vuesurlasecuritepublique/\#

165 http://donnees.ville.montreal.qc.ca/dataset/contrats-et-subventions-api
} 
and requires that citizens are equipped with information and the necessary tools to understand how choices in government are made. ${ }^{166}$ Openness also refers to citizens being empowered to build from government information and services.

\subsubsection{Citizen Engagement}

As stated earlier, citizens both directly and indirectly informed the smart city strategy's focus areas. Anyone can access information about the smart city strategy and action plan via the BVIN's website, a Facebook page, and ideas page. ${ }^{167}$

Some of the projects presented in the city's action plan derive from the $J e$ Vois Montréal event. The event was launched in 2014 by a coalition of businesses and civic leaders. ${ }^{168} \quad 181$ recommended project ideas arose from the event, some

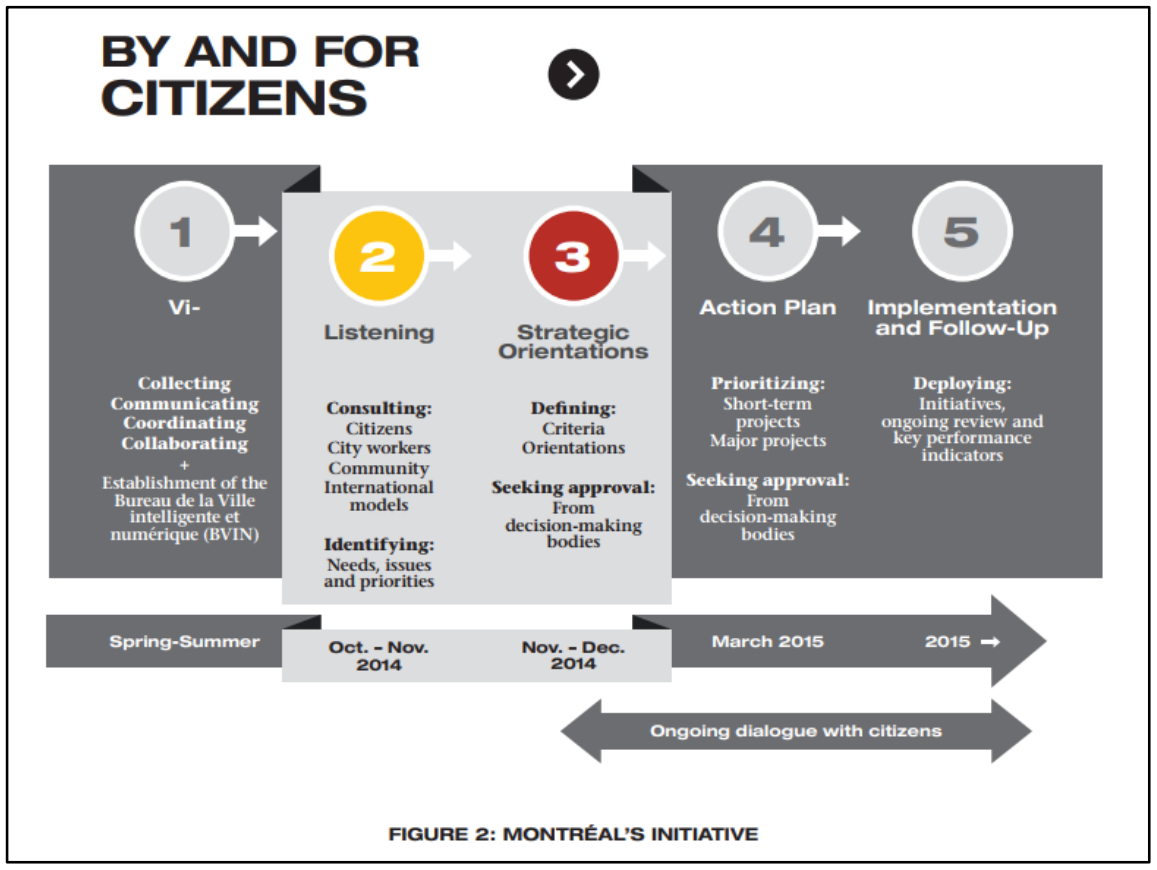

Figure 19 - Citizen Engagement Figure (Source: Montréal Smart and Digital City Strategy (2014-2017) p. 5) of which became part of the smart city action plan. Je Fais Montréal later emerged as a forum for the city, stakeholders, and citizens to consult on and monitor how well these projects that arose from Je Vois Montréal were progressing. ${ }^{169}$ The city set up the Conseil Avis Développeurs Novateurs (ADN), consisting of 22 members from various sectors and the Mayor as its Chair, to provide support to the Je Fais initiative.

The city is in the process of revamping its citizen engagement strategy. The strategy will encourage continued outreach to civil society groups as projects unfold and there are plans to reach out to the Je Fais forum to continue to mobilize civil society engagement over time.

\subsubsection{Deployment of Geospatial and ICT Data}

Geo-enabled information is important to understanding City operations due to the distinct way that each municipal borough manages its territory. Thus, la Ville de Montréal's IT Services staff are working to revise the municipal GIS strategy and increase the ability to geocode information. Currently, most of the city's geospatial data is specified by addresses and place names.

\footnotetext{
166 BVIN at la Ville de Montréal. Personal interview with Rachel Bloom. May 24 $4^{\text {th }}, 2017$.

$167 \mathrm{http}: / /$ villeintelligente.Montréal.ca/en/participate

168 "Faire Montréal," Faire Montréal: À propos. Accessed March 15, 207. https://fairemtl.ca/fr/je-fais-Montréal.

169 "Faire Montréal," Faire Montréal: À propos. Accessed March 15, 207. https://fairemtl.ca/fr/je-fais-Montréal.
} 
The city has focused on improving access to government data via the adoption of standards for open data. For instance, the Montréal has adopted an Open Contracting Data Standard for open data about public procurement contracts ${ }^{170}$. In addition, Montréal has considered but ultimately did not adopt the City Service Development Kit ${ }^{171}$ (CitySDK) that specifies a set of open APIs for sharing data about city services with developers.

Generally, the visualization of procurement data, ${ }^{172}$ crime mapping, ${ }^{173}$ and traffic cameras map, ${ }^{174}$ are launched on an ad-hoc basis, but city staff hope to develop a more unified approach for visualizing geospatial information. ${ }^{175}$ Currently there are a diverse set of geo-visualization tools in use such as GMap and Esri. The city publishes some of its open geospatial data in machinereadable formats that are open (e.g. GeoJSON and KMZ) and proprietary (ESRI shapefiles).

The city also publishes municipal maps from their Open Data Catalogue and spatial metadata specify the data's spatial reference, model element accuracy, data types, and boundaries. As for cartographic data standards, the Quebec Ministry of Transport guidelines ${ }^{176}$ have been adopted since 2015. The Geomatics Division has collected Light Detection and Ranging (LiDAR) data since 2015 and these have been made open data, as are their visualizations. These data provide 3D topographic information for digital terrain models, contour lines, planning, calculating tree height, mapping building roofs, 3D modeling of the city, and beyond.

The city has a structured process to archive data and documents ${ }^{175}$ in place, but does not yet have a process for data derived from IoT, although a team in the IT branch aims to secure these data.

Montréal is the first city in Canada to partner with Waze, a proprietary crowdsourced traffic and navigation application. The city signed a free partnership with Waze for a two-year pilot project that exchanges geo-located traffic obstruction data to Waze, while Waze shares their real-time and anonymous incident and slow-down information. ${ }^{177}$

Montréal also provides real-time sensor traffic data on their open data portal. ${ }^{178}$ These are disseminated according to the MQTT protocol, which is now an Organization for the Advancement of Structured Information Standards (OASIS) standard. The portal also includes information about the data's methodology and its data dictionary for some off their data. In addition to real time traffic data from sensors, the city also releases an air quality index at an hourly rate.

\footnotetext{
170 http://standard.open-contracting.org/latest/en/

171 https://www.citysdk.eu/

172 http://bit.ly/2nGaDuu

173 https://ville.Montréal.qc.ca/vuesurlasecuritepublique/\#

174 http://ville.Montréal.qc.ca/circulation/

175 BVIN at la Ville de Montréal. Interview with Rachel Bloom. May 24 $4^{\text {th }}, 2017$.

176 https://www.transports.gouv.qc.ca/fr/entreprises-partenaires/entreprises-reseaux-routier/guidesformulaires/Pages/arpentage-conception.aspx

177 Galang, Jessica. "Ville de Montréal Signs Two-Year Pilot Project Partnership with Waze," Last modified April 25, 2016. Accessed March 17, 2017. http://betakit.com/city-of-Montréal-signs-two-year-pilot-project-partnership-withwaze/.

${ }^{178}$ http://donnees.ville.Montréal.qc.ca/dataset/circulation-mobilite-temps-reel
} 
City data are not centralized; instead, Montréal's open architecture principle in their strategy tries to make data accessible to city staff via open APIs. The city has a data sharing partnership with the Centre de Recherche Informatique de Montréal and McGill University for the development of prototypes and to test data interoperability projects. These agreements include compliance to open data standards and software, and those data shared by the municipality and derived from the pilot remain the city's IP.

\subsubsection{Feedback and Monitoring Progress}

Montréal's smart city progress has been monitored from 2012 to 2016 with a set of performance indicators by the municipal service de la performance organisationnelle (SPO). ${ }^{179}$ Indicators are published online as part of the Vue sur les Indicateurs de Performance, a part of the Smart and Digital City Action Plan ${ }^{180}$ (see Figure 20 below). The 147 performance indicators monitor 20 organizational activities and are part of two large indicators systems, the Municipal Benchmarking Network Canada and the Quebec Ministry of Municipal Affair and Land Occupancy initiatives. Some of the data for these indicators are derived from public surveys.

The city has not adopted international standards for the smart city because it is hard to translate these according to complex ongoing projects and processes. Thus, to benchmark smart city progress, the approach has been delivery of satisfaction surveys about smart city programs and projects. ${ }^{181}$

Feedback from citizens and the media to date has been mixed. One example of a positive smart city impact is the vehicle signaling system for viaducts, which has reduced downtown accidents by 50 percent. ${ }^{182}$

Media have also been critical of project shortfalls. The Info-Neige app, for example, has had issues delivering data to users ${ }^{183}$ and the app reportedly did not reduce the number of tows that occurred

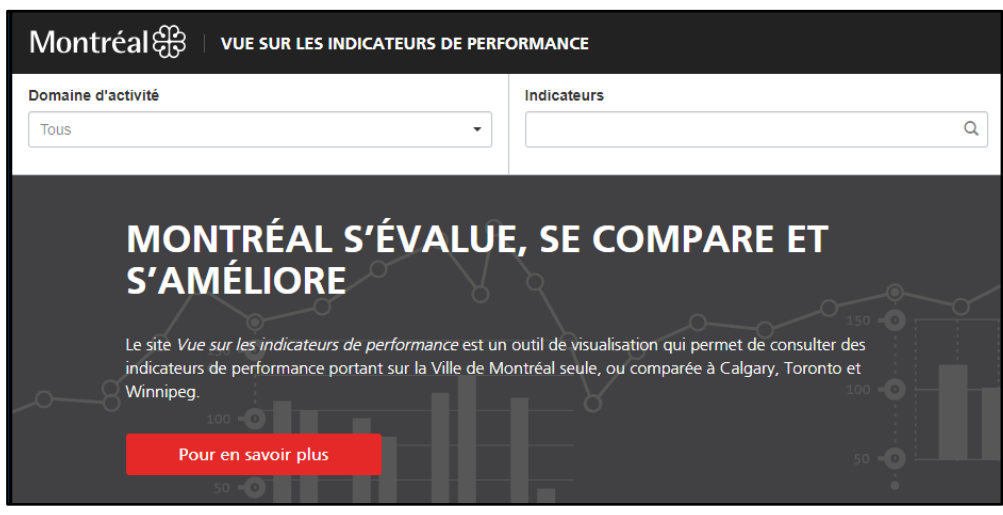

Figure 20 - Snapshot of Benchmarking of City Services (Source: http://ville.montreal.qc.ca/vuesurlesindicateurs/index.php)

\footnotetext{
179 BVIN at la Ville de Montréal. Interview with Rachel Bloom. May 24 $4^{\text {th }}, 2017$.

${ }^{180} \mathrm{http}: / /$ ville.Montréal.qc.ca/vuesurlesindicateurs/index.php

${ }^{181}$ BVIN at la Ville de Montréal. Personal interview with Rachel Bloom. May 24 ${ }^{\text {th }}, 2017$.

182 "Monitorage des structures de voies," Ville de Montréal. Modified on July 12, 2012. Accessed March $18,2017$. http://ville.montreal.qc.ca/portal/page?_pageid=8957,99681596\&_dad=portal\&_schema=PORTAL\&id=4416\&ret= http://ville.montreal.qc.ca/pls/portal/url/page/transports_fr/rep_publications/rep_actualites/coll_actualites.

183 Marchal, Mathia. "Le déneigement intelligent connaît des bogues," Journal Metro. Last modified January 5 , 2017. Accessed on March 20. http://journalmetro.com/actualites/Montréal/1072943/le-deneigement-intelligentconnait-des-bogues/.
} 
over three winters. ${ }^{184}$ Additionally, delays in the launch of iBus, a digital platform for delivering real-time and geo-located bus itinerary information was delayed, partly due to the procurement of a new radio-communication system equipment linked to iBus. ${ }^{185}$

\subsubsection{Summary and Observations}

Montréal is the only city out of the four that has published an action plan and performance indicators to measure the progress of their smart city efforts. Furthermore, the Montréal Smart and Digital City Strategy is unambiguously focused on input from residents and has judiciously engaged residents to identify urban issues and propose solutions to these issues. Moreover, strategic and reference documents, as well as visions, definitions, timelines, and methods were made available to the public via the BVIN's website. A scan of these documents suggest that international smart city frameworks and European Union funded initiatives informed the creation of the Strategy. In addition, principles of accountability and transparency are included as guiding principles for the smart city.

The Montréal Smart and Digital City Action Plan is notably ambitious, with a total of 70 projects included in the official report presented to the municipal Executive Committee. The city has demonstrated a commitment to tackling mobility issues via open data and innovative partnerships. The city has also demonstrated a commitment to working with and supporting local technology startups.

While the Montréal has demonstrated a commitment to engaging local technology startups, resident engagement by the city appears to have waned over time. One of the reasons for this may be the absence of an interdepartmental decision-making committee to provide sustained leadership to the business units that operationalize the Action Plan's programs and projects.

Overall, and as has been observed in other cities, best practices related to IoT, open and geospatial data, SaaS, data management at the device level, privacy, human rights, ethics, and security are generally missing from Montréal's publicly available smart city documentation. The BVIN, however, does emphasize piloting open standards and open source for data interoperability and geo-enabling and visualizing open data to improve its accessibility. Finally, the recent publication of guidelines for smart cities for the public good by the Quebec Commission de L'éthique en Science et en Technologie, in addition to the fact that a new Mayor has recently taken office, will likely influence and inform Montréal's open smart city plans for the future.

\footnotetext{
${ }^{184}$ Marchal, Mathia. " Nouvelle application InfoNeige: les Montréalais plus actifs lors d'opérations de déneigement," Journal Metro. Last modified February 14, 2018. Accessed on February 28, 2018. http://journalmetro.com/actualites/Montréal/1072943/le-deneigement-intelligent-connait-des-bogues/ . ${ }^{185}$ Shaffer, Marie-Eve. "Un contrat pour iBus prolongé au coût de 1,8M\$\$," Journal Metro. Last modified February 16, 2016. http://journalmetro.com/actualites/Montréal/917963/un-contrat-pour-ibus-prolonge-au-cout-de-18m/: Magder, Jason. "Still waiting: Web and digital bus tracking program postponed, again," Montréal Gazette. Last modified January 5, 2017. Accessed March 20, 2017. http://Montréalgazette.com/news/local-news/still-waiting-weband-digital-bus-tracking-program-postponed-again.
} 
Table 7 - Summary of la Ville de Montréal Smart City Initiative

\begin{tabular}{|c|c|c|}
\hline $\begin{array}{c}\text { Smart City } \\
\text { Component/Process }\end{array}$ & Current State & Considerations for the Future \\
\hline $\begin{array}{l}\text { Smart City } \\
\text { Strategy }\end{array}$ & $\begin{array}{l}\text { Montréal, Smart and Digital City: } \\
\text { 2014-2017 Strategy (2014) }\end{array}$ & -- \\
\hline $\begin{array}{c}\text { Smart City } \\
\text { Roadmap \& } \\
\text { Guiding Principles }\end{array}$ & $\begin{array}{l}\text { Montréal, Smart and Digital City: } \\
\text { 2015-2017 Action Plan (2015) }\end{array}$ & -- \\
\hline Urban Plan & $\begin{array}{l}\text { There is a Development Plan for } \\
\text { the city overall, however each } \\
\text { borough manages their territory } \\
\text { differently. }\end{array}$ & $\begin{array}{l}\text { Will the Development Plan and } \\
\text { borough plans interoperate and } \\
\text { mandate the implementation of } \\
\text { smart city components? }\end{array}$ \\
\hline $\begin{array}{l}\text { Governance } \\
\text { Structure }\end{array}$ & $\begin{array}{l}\text { There is no interdepartmental } \\
\text { committee or commission that } \\
\text { acts in a decision-making capacity } \\
\text { for the Strategy; There is a } \\
\text { member on the Executive } \\
\text { Committee responsible for the } \\
\text { smart city; The BVIN promotes, } \\
\text { supports, and facilitates smart city } \\
\text { initiatives and business units } \\
\text { operationalize projects. }\end{array}$ & $\begin{array}{c}\text { Who utlimately decides on strategic } \\
\text { pathways for the smart city in the } \\
\text { long term? }\end{array}$ \\
\hline $\begin{array}{l}\text { Dedicated } \\
\text { Personnel }\end{array}$ & $\begin{array}{l}\text { Personnel are responsible for } \\
\text { operationalizing smart city } \\
\text { projects within their own } \\
\text { departments. }\end{array}$ & $\begin{array}{l}\text { Will there be dedicated legal, } \\
\text { privacy and security } \\
\text { personnel/function? }\end{array}$ \\
\hline Dedicated Unit & $\begin{array}{l}\text { BVIN's role is to promote, } \\
\text { support and facilitate projects } \\
\text { included in the Action Plan. }\end{array}$ & $\begin{array}{l}\text { Will there be dedicated legal, } \\
\text { privacy and security } \\
\text { personnel/function? }\end{array}$ \\
\hline $\begin{array}{l}\text { Inventory of } \\
\text { initiatives }\end{array}$ & $\begin{array}{l}\text { Action Plan specifies } 70 \text { smart } \\
\text { city projects; It is not clear if there } \\
\text { was a systematic inventory of } \\
\text { initiatives prior to the Strategy. }\end{array}$ & $\begin{array}{l}\text { What is the starting benchmark for } \\
\text { the city to measure progress of their } \\
\text { smart city initiative? }\end{array}$ \\
\hline Procurement & $\begin{array}{l}\text { Strategy includes collaboration } \\
\text { with venture capital firms; } \\
\text { Montréal partners with a smart } \\
\text { city accelerator; The city openly }\end{array}$ & $\begin{array}{l}\text { What will the guiding principles, } \\
\text { standards, open source, and etc., be } \\
\text { for procuring smart city } \\
\text { technologies? Will terms such as }\end{array}$ \\
\hline
\end{tabular}




\begin{tabular}{|c|c|c|}
\hline & $\begin{array}{l}\text { publishes and visualizes } \\
\text { procurement data online. }\end{array}$ & $\begin{array}{l}\text { open source, privacy and } \\
\text { transparency by design, and } \\
\text { cybersecurity standards guide } \\
\text { requests for proposals? Will the } \\
\text { city retain data, hardware and } \\
\text { software IP? }\end{array}$ \\
\hline Engagement & $\begin{array}{l}\text { Strong evidence of citizen } \\
\text { consultation and co-creation from } \\
\text { the beginning; Strategy relied on } \\
\text { transparent consultation } \\
\text { processes; Je Fais } M T L \text { forum } \\
\text { monitors development of projects. }\end{array}$ & $\begin{array}{l}\text { How will "smart citizens" be } \\
\text { empowered and included in a } \\
\text { decision making throughout project } \\
\text { life cycles and in the long term? }\end{array}$ \\
\hline Openness & $\begin{array}{l}\text { Prioritization of open standards; } \\
\text { The municipality retains data IP in } \\
\text { pilots; Open data and open } \\
\text { interoperable IT architecture are } \\
\text { part of policy guidelines; There is } \\
\text { strong collaboration with civic } \\
\text { technology organizations; Open } \\
\text { data policy specifies standard } \\
\text { principles by the Sunlight } \\
\text { Foundation; Real time and } \\
\text { telemetry data have been } \\
\text { published openly; There is } \\
\text { deployment of open standards } \\
\text { (i.e., Open Contracts Data } \\
\text { Standard for public procurement } \\
\text { and Open } 311 \text { for service } \\
\text { requests). }\end{array}$ & $\begin{array}{l}\text { Will open source be part of being } \\
\text { an open smart city? Will } \\
\text { comittment to open data be upheld } \\
\text { when procuring smart city } \\
\text { technologies? }\end{array}$ \\
\hline Spatial Data & $\begin{array}{l}\text { No clear connection of spatial } \\
\text { sciences informing the Strategy; } \\
\text { Evidence of innovative } \\
\text { deployment of geospatial data, } \\
\text { open publication of LiDAR data } \\
\text { for 3D modeling and interactive } \\
\text { geo-visualized data; There are } \\
\text { metadata and documented } \\
\text { standards for spatial open data. }\end{array}$ & $\begin{array}{l}\text { How will the Montréal ultimately } \\
\text { decide on the adoption of standards } \\
\text { for integrating geospatial data? } \\
\text { How will data be geocoded? Will } \\
\text { geocoding be mandated? Will } \\
\text { groups that specialize in GIS and } \\
\text { mapping techniques inform smart } \\
\text { city plans? }\end{array}$ \\
\hline
\end{tabular}




\begin{tabular}{|c|c|c|}
\hline Crowdsourcing & $\begin{array}{l}\text { There is some deployment of } \\
\text { crowdsourced data via partnership } \\
\text { with WAZE. }\end{array}$ & $\begin{array}{l}\text { How are crowdsourced data or } \\
\text { citizen science intiatives being } \\
\text { utilized for the smart city? }\end{array}$ \\
\hline \multirow[t]{2}{*}{$\begin{array}{c}\text { Standards \& } \\
\text { Interoperability }\end{array}$} & $\begin{array}{l}\text { City is piloting open APIs for } \\
\text { sharing city data; City SDK APIs } \\
\text { were considered but not adopted. }\end{array}$ & \multirow{2}{*}{$\begin{array}{l}\text { Will interoperabiliy of software and } \\
\text { data be specified? Will the smart } \\
\text { city be a platform that others plug } \\
\text { into? }\end{array}$} \\
\hline & $\begin{array}{l}\text { Open interoperable architecture is } \\
\text { a policy guideline for the strategy. }\end{array}$ & \\
\hline Privacy & $\begin{array}{l}\text { Privacy policies for IoT and smart } \\
\text { city are not clearly communicated; } \\
\text { Montréal has a team in IT that } \\
\text { advises on privacy issues at the } \\
\text { beginning of technology } \\
\text { initiatives; Ex-post privacy } \\
\text { assessments are enacted for older } \\
\text { systems. }\end{array}$ & $\begin{array}{l}\text { Will privacy by design principles } \\
\text { be applied for smart city } \\
\text { technologies, such as sensor } \\
\text { systems? }\end{array}$ \\
\hline Security & $\begin{array}{l}\text { There is a team devoted to } \\
\text { security in the IT branch. }\end{array}$ & $\begin{array}{l}\text { What security standards and } \\
\text { practices will be applied in a smart } \\
\text { city context, such as for data } \\
\text { captured by meters and sensors and } \\
\text { at the device level? }\end{array}$ \\
\hline Archiving & $\begin{array}{l}\text { There is an archiving strategy for } \\
\text { city owned information but it is } \\
\text { not overtly linked to smart city } \\
\text { data. }\end{array}$ & $\begin{array}{c}\text { How will data preservation be } \\
\text { considered for emergent smart city } \\
\text { technologies, especially IoT and } \\
\text { SaaS? }\end{array}$ \\
\hline
\end{tabular}




\subsection{The City of Ottawa}

The City of Ottawa, situated at the juncture of the Ottawa River and the Rideau River and Canal on the traditional unceded territory of the Algonquin Anishnaabeg people, was incorporated in 1855 and is Canada's national capital. The city's population is growing, with an enumerated population increase of 5.8 percent from 2011 to $2016 .{ }^{186}$ Ottawa's suburbs are surrounded by prime agricultural lands, interspersed with wetland and forests and some Canadian Shield. ${ }^{187}$

In 2001, the City of Ottawa amalgamated 11 urban and rural municipalities and a regional government. ${ }^{187}$ The City of Ottawa is a single-tier municipality governed by the 24-members that sit on Council. Residents in the 23 wards elect a city councilor and a Mayor by a citywide vote. The cities of Gatineau and Ottawa make up the National Capital Region (NCR) on both sides of the Ontario and Quebec border. The Cities of Ottawa and Gatineau and the federal government partner on a range of issues that relate to the NCR.

The federal government and high technology industries dominate Ottawa's economy. In addition, Ottawa hosts three universities, two publicly funded colleges, a variety of private and government research facilities, an active business community, and a well-educated workforce. ${ }^{188}$ Ottawa has a diverse population, with an estimated 1 in 4 residents born outside of Canada. ${ }^{189}$

The City of Ottawa Official Plan aims to address urban challenges such as housing, employment, resource intensification, mobility, and aging residents ${ }^{190}$ to address the projected population growth of the next decade. The 2020 Growth Management Strategy is guided by the following principles: a caring and inclusive City, a creative City rich in heritage and unique in identity, a green and environmentally sensitive City, a City of distinct, livable communities, an innovation City where prosperity is shared among all, a responsible and responsive City, and a healthy and active City. ${ }^{191}$ The Official Plan also specifies government accountability, open and participatory processes, public awareness, access to quality information, a strong rural economy and distinct rural countryside, a focus on walking, cycling, easy mobility, and transit, a green city, and citizen engagement. ${ }^{191}$ Ottawa also has master plans for transportation, greenspace, and infrastructure as part of its Official Plan. ${ }^{192}$

\footnotetext{
186 Statistics Canada. 2017. Focus on Geography Series, 2016 Census. Statistics Canada Catalogue no. 98-404X2016001. Ottawa, Ontario. Analytical products, 2016 Census http://www12.statcan.gc.ca/censusrecensement/2016/as-sa/fogs-spg/Facts-csd-eng.cfm?LANG=Eng\&GK=CSD\&GC=350.

${ }^{187}$ http://ottawa.ca/en/city-hall/planning-and-development/official-plan-and-master-plans/official-plan/volume-1official\#pdf-version

188 http://ottawa.ca/en/city-hall/planning-and-development/official-plan-and-master-plans/official-plan/volume-1official\#pdf-version

${ }^{189} \mathrm{http}: / /$ ottawa.ca/en/city-hall/planning-and-development/official-plan-and-master-plans/official-plan/volume-1official

190 http://ottawa.ca/en/node/1009708

$191 \mathrm{http} / / /$ documents.ottawa.ca/sites/documents.ottawa.ca/files/documents/con015300.pdf

192 http://documents.ottawa.ca/sites/documents.ottawa.ca/files/documents/section_05_en.pdf
} 
Council Priorities are set out in the City of Ottawa 2015-2018 Strategic Plan ${ }^{193}$ and these include economic prosperity, transportation and mobility, sustainable environmental services, healthy and caring communities, service excellence, and financial sustainability (see Figure 21).

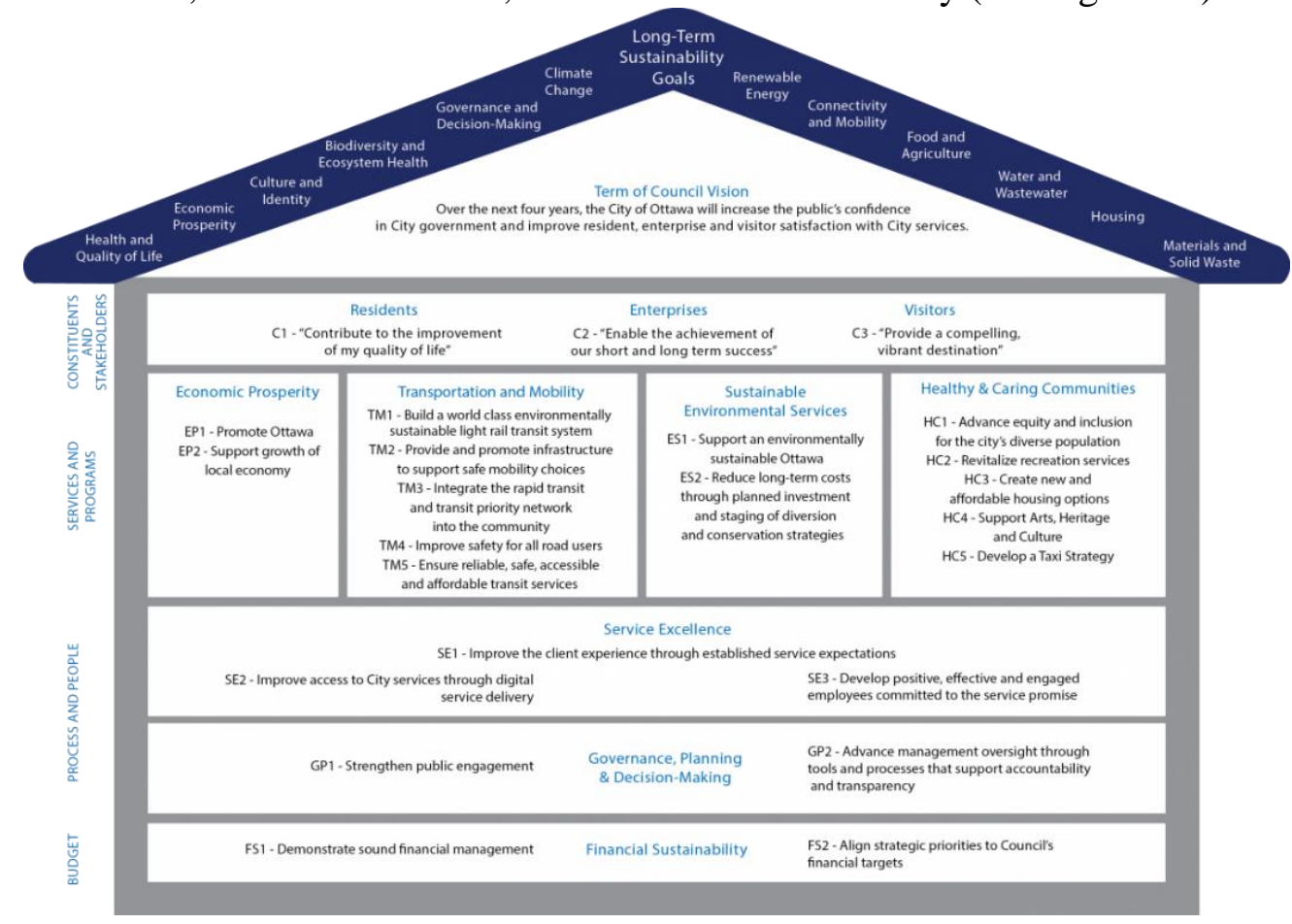

Figure 21 - City of Ottawa's Strategy Map (Source:

http://ottawa.ca/en/city-hall/accountability-and-transparency/corporateplanning-and-performance-management\#city-strategy-map)

\subsubsection{Strategy}

A series of events and consultations informed Ottawa's smart city strategy. In March 2016, city staff introduced the smart city as a concept to the IT Subcommittee with an information report and presentation. The following month, Invest Ottawa, Hydro Ottawa, and the City of Ottawa hosted an invitation-only "Building the Smart City" workshop as input for a Smart City Playbook. Hydro Ottawa hired private urban consultants, David Sandel \& Associates ${ }^{194}$ and later, Invest Ottawa hired Campbell Patterson ${ }^{195}$ to research smart city practices in other cities (i.e., cities of Toronto and Kingston). ${ }^{196}$ Sandel \& Associates helped develop Ottawa's Smart City Playbook, ${ }^{197}$ which compiled the workshop's outcomes and plans for developing a common understanding of a smart city and identifying smart city projects and tactics. The workshop event was organized around a

\footnotetext{
${ }^{193}$ http://documents.ottawa.ca/sites/documents.ottawa.ca/files/documents/2015 2018 strategic_plan_en.pdf

${ }^{194} \mathrm{http}: / /$ sandel-associates.com/index.php/The-CMS/the-team.html

195 https://www.campbellpatterson.com/

${ }^{196}$ Economic Development, Planning, Infrastructure and Economic Development at the City of Ottawa. Personal interview with Rachel Boom. June 5, 2017.

${ }^{197}$ http://sandel-associates.com/index.php/Latest/bmcd-press-release.html
} 
set of focus areas and attended by representatives from the private sector, public officials, MUSH organizations, and postsecondary institutions.

In June of 2016, the Finance and Economic Development Committee (FEDC) and City Council approved the Smart City Initiatives ${ }^{198}$ report. FEDC was given the responsibility to govern the smart city, as it spans across a number of City Standing Committees, providing the possibility for a more integrated approach. Staff were directed to develop a smart city vision and roadmap for Ottawa.

In September of 2017, Ottawa held a Smart City Symposium to present and receive feedback on the proposed draft Smart City 2.0 strategy. This was another-invitation only event and included stakeholders from a variety of sectors. ${ }^{199}$ Figure 22 provides a timeline of the events leading up to the approval of Smart City 2.0 by FEDC and City Council.

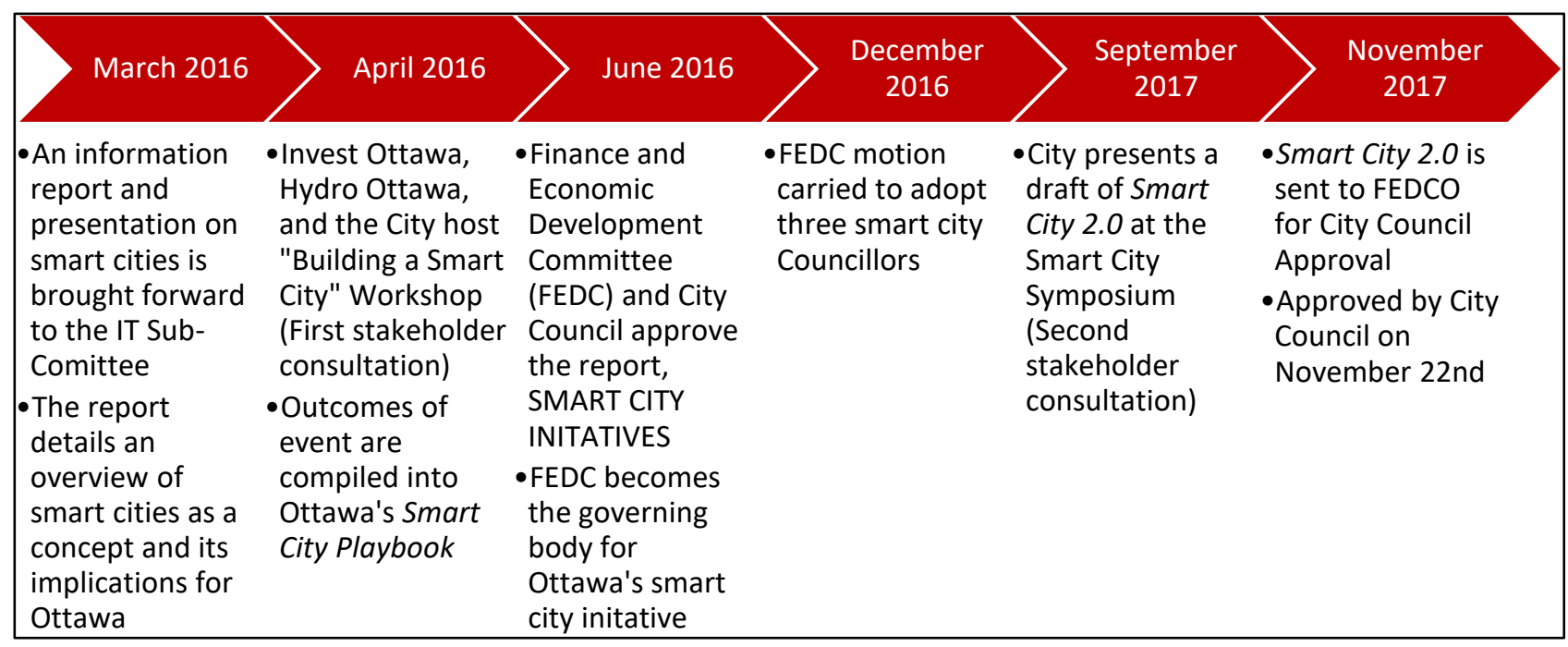

\section{Figure 22 - Timeline of Ottawa's Smart City Initiative}

Smart City 2.0 outlines smart city goals and some initiatives. The core of the smart city strategy is "the increasing importance of technology as a means of improving and enhancing the lives of the residents and businesses a City serves". ${ }^{200}$ Furthermore, the document states that Ottawa is already well advanced as a smart city but requires a strategy to proactively maintain its smart city edge. Smart City 2.0 intends to ensure that technology is not an "afterthought", but "something embedded within all the city does". ${ }^{200}$

Smart City 2.0 sets the priorities for City Council to advance Ottawa as a smart organization and its pathways for competing in the global economy. Representatives from Ottawa's Planning, Infrastructure and Economic Development Department identified infrastructure as a key element

\footnotetext{
198 http://app05.ottawa.ca/sirepub/cache/2/dyw4sb2t5bweoq0hr5bgvuhz/41296511222017011312203.PDF

199 Economic Development, Planning, Infrastructure and Economic Development at the City of Ottawa. Personal interview with Rachel Boom. June 5, 2017.

200 Smart City 2.0. Submitted to the Finance and Economic Development Committee. City of Ottawa. November 2017. http://app05.ottawa.ca/sirepub/cache/2/dyw4sb2t5bweoq0hr5bgvuhz/4851211106201709281159.PDF.
} 
of the initiative. ${ }^{201}$ It is anticipated that the forthcoming smart city action plan will establish an informed and official definition of a smart city for Ottawa.

The goals ${ }^{200}$ presented by Smart City 2.0 are as follows:

1. Connected City: Create a city where all residents and businesses are connected in an efficient, affordable and ubiquitous way.

2. Smart Economy: Stimulate economic growth by supporting knowledge-based business expansion and attraction, local entrepreneurs, and smart talent development.

3. Innovative Government: Develop new and innovative ways to impact the lives of residents and businesses through the creative use of new service delivery models, technology solutions, and partnerships.

According to Smart City 2.0, the City of Ottawa's role in achieving these goals are to:

1. Be a leader and catalyst in bringing together all of Ottawa's smart city stakeholders, programs, and initiatives under a single strategy and common set of goals; and

2. Work collaboratively with residents, businesses, and smart city eco-system players (knowledge-based businesses and entrepreneurs, Invest Ottawa and the city's economic development organizations, post-secondary institutions, Hydro Ottawa and utility providers, research institutions, and non-governmental, non-profit, and social enterprises) to advance and implement Smart City 2.0.

Appendix B provided details about the Strategy's goals, some initiatives, the currently identified collaborative stakeholders, as well as anticipated and current smart city initiatives.

The creation of Smart City 2.0 was motivated by Council's priorities of promoting Ottawa and advancing the city in the global economy. Thus, a driver for the strategy is, "the escalating "war for talent' dominating the global economy, dictating which cities succeed in attracting the most successful companies and well-paid workforce".

An action plan will follow the strategy and include a prioritization of smart city initiatives and a timeline for the smart city working group; a Key Performance Indicators (KPI) framework to measure the success of Smart City 2.0 and a dashboard to provide on-going progress reports to residents, businesses, and partners; a governance model for Smart City 2.0; the development of a web-presence and digital platform, as well as forums such as hackathons, to actively engage residents, businesses, and smart city partners in the co-creation and implementation of Smart City 2.0 .

\subsubsection{Perceived Beneficiaries}

Representatives at the City of Ottawa consider residents, businesses and city staff as beneficiaries of Ottawa's smart city initiative. Smart City 2.0 aims to ensure that residents access information more easily, that city staff can effectively and efficiently deliver services in a cost-effective and timely manner to respond to the needs of the community, and that businesses are better positioned

${ }^{201}$ Economic Development, Planning, Infrastructure and Economic Development at the City of Ottawa. Personal interview with Rachel Boom. June 5, 2017. 
to compete effectively and efficiently in the global economy. ${ }^{202}$ Furthermore, rural areas are also expected to benefit from a smart precision agriculture node that aims to enhance connectivity and technology for rural economic development. Ottawa's professional network and an online forum are expected to communicate the benefits of the smart city to its beneficiaries. ${ }^{202}$

\subsubsection{Components}

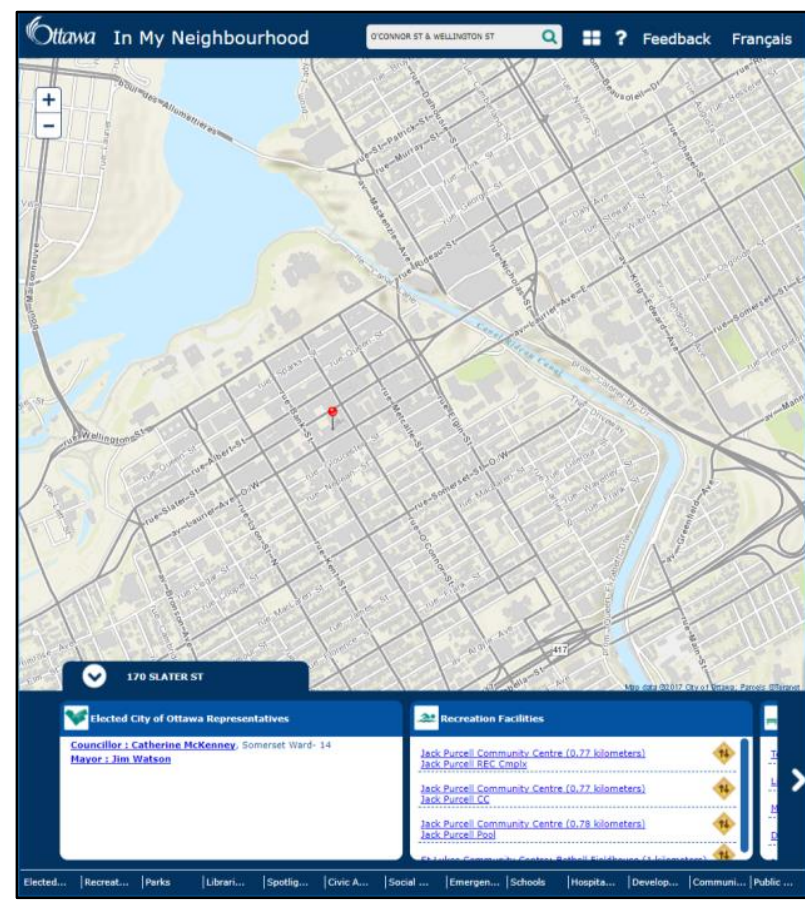

Figure 23 - Snapshot of Ottawa's In My Neighborhood (source: http://maps.ottawa.ca/imn/desktop.htm)

Table 8 lists operational smart city initiatives where the City of Ottawa is an active participant. The identified projects, reports, and programs are public facing information and some are within Ottawa's Smart City 2.0. Initiatives include: OC Transpo's real-time CCTV systems on buses, Hydro Ottawa's automated smart meter system, deployment of remote sensing equipment to detect terrain details and pipeline issues for infrastructure services, LED streetlighting conversion program, connecting cityowned salt truck to an automated salt management system, map based and location based services (see Figure 23), and autonomous vehicle test-tracking. The city has installed 285 KM of dark fibre to support their smart grid initiative and has increased interconnectivity of smart meters and other components that are intended to enable the system's operational flexibility, efficiency, better planning and maintenance. ${ }^{203}$ The city also operates a traffic control centre that manages traffic and a Paramedic Control Centre in collaboration with the Province. ${ }^{204}$ More information about some of Ottawa's current smart city initiatives are described in more detail below.

Table 8 - City of Ottawa Smart City Technologies and Programs

\begin{tabular}{|c|l|}
\hline Current Smart City Related Activities & \multicolumn{1}{|c|}{ Type of Smart City Component } \\
\hline OC Transpo CCTV real-time data system & $\begin{array}{l}\text { Sensors, intelligent transportation systems, } \\
\text { smart mobility, control rooms, surveillance }\end{array}$ \\
\hline Traffic Control Centre and Traffic Map & Smart mobility, control rooms \\
\hline Hydro Ottawa's smart meter system & Meters, smart energy, control rooms \\
\hline
\end{tabular}

\footnotetext{
${ }^{202}$ Economic Development, Planning, Infrastructure and Economic Development at the City of Ottawa. Personal interview with Rachel Boom. June 5, 2017.

203 "Smart Meters," Hydro Ottawa (webpage). Accessed March 26, 2017. https://hydroottawa.com/accounts-andbilling/business/time-of-use/smart-meters.

204 "Eyes on the City: Our Traffic Control Centre," Ottawa City News. October 18, 2013.

http://ottawa.ca/en/news/eyes-city-our-traffic-control-centre.
} 


\begin{tabular}{|c|c|}
\hline Autonomous Vehicle Cluster & $\begin{array}{l}\text { Autonomous vehicle test-bed and research, } \\
\text { IoT }\end{array}$ \\
\hline$\underline{\text { Salt truck management system }}$ & $\begin{array}{l}\text { Smart technology, smart services and } \\
\text { operations }\end{array}$ \\
\hline $\begin{array}{l}\text { Hydro Ottawa's installation of } 285 \mathrm{KM} \text { of } \\
\text { dark fibre for their smart grid initiative }\end{array}$ & $\begin{array}{l}\text { Smart energy, telecommunications, smart } \\
\text { infrastructure, and IoT enabler }\end{array}$ \\
\hline Open Data Catalogue & Open data, digital public services \\
\hline$\underline{\text { Innovation Centre at Bayview Yards }}$ & $\begin{array}{l}\text { Smart city devices, smart city accelerators, } \\
\text { smart innovation }\end{array}$ \\
\hline LED street lights conversion program & Smart energy \\
\hline$\underline{\text { Building automation system integrator }}$ & $\begin{array}{l}\text { Smart energy, remote operation of building } \\
\text { heating and ventilation }\end{array}$ \\
\hline Mobile workforce initiative & $\begin{array}{l}\text { Mobile-services, location based services, } \\
\text { collaboration tools }\end{array}$ \\
\hline Solar Panel Installations & Smart energy \\
\hline Innovation Pilot Program & Smart accelerator \\
\hline$\underline{\text { Traffic control center }}$ & $\begin{array}{l}\text { Smart traffic management, control rooms, } \\
\text { smart mobility }\end{array}$ \\
\hline Paramedic Control Room & Safe City \\
\hline Open311 & $\begin{array}{l}\text { Open data standards, service request } \\
\text { management, geo-enabled data, citizen centric } \\
\text { services }\end{array}$ \\
\hline$\frac{\text { Analytics Unit, Service Analytics and }}{\frac{\text { Planning, Service Innovation and }}{\text { Performance Department }}}$ & Data analytics, evidence-based policy making \\
\hline$\underline{\text { Connected Water pilot project }}$ & $\begin{array}{l}\text { IoT, smart infrastructure, environmental } \\
\text { sensor, sustainability, analytics, smart } \\
\text { technology procurement }\end{array}$ \\
\hline GeoOttawa map & $\begin{array}{l}\text { Open data map, geo-visualization, interactive } \\
\text { web mapping }\end{array}$ \\
\hline In My Neighbourhood & $\begin{array}{l}\text { Interactive map, open public facilitates data, } \\
\text { location based services }\end{array}$ \\
\hline$\underline{\text { ArcGIS and Esri Server }}$ & $\begin{array}{l}\text { GIS management, geodatabases, metadata } \\
\text { standards for geospatial data, open data } \\
\text { component, map based services }\end{array}$ \\
\hline MyServiceOttawa & Citizen-centric services and tools \\
\hline MBNCanada & Performance indicators for City services \\
\hline Ottawa Nav & $\begin{array}{l}\text { Multimodal mobile application, real-time } \\
\text { traveler information }\end{array}$ \\
\hline Technology Roadmap 2013-2016 & $\begin{array}{l}\text { IT planning, CSM, Information Security, GIS } \\
\text { enterprise }\end{array}$ \\
\hline
\end{tabular}




\subsubsection{Smart Water Pilot}

The city is implementing a pilot project for a connected water system, provided by Rogers Communications and Ericsson. ${ }^{205}$ The system uses sensors, cloud, and mobile broadband technologies for automated water quality testing at several locations throughout that NCR. ${ }^{206}$ The eight sensors provided by Ericsson collected data on water turbidity, conductivity and temperature and send them to a central database. The service collects and delivers these measurements every 30 minutes. The city's role was to pilot the system to take water quality readings and city staff provided feedback on the technology to the project's partners.

\subsubsection{IoT Research Cluster}

Ottawa is renowned for its high concentration of technology firms in the IoT space, most notably: QNX (a leader in the autonomous car), Macadamian (a software and design firm that develops innovative applications), Purple Forge (an Ottawa based Software as a Service (SaaS) provider of mobile-first community and self service solutions ${ }^{207}$ ), Wind River (Intel) (a global leader in software for intelligent connected systems), CENX (a company that provides predictive, real-time, and historical analytics services ${ }^{208}$ ), Spring2Innovation (an innovation consulting company that offers services in consulting, facilitation, innovation training \& certification, speaking engagements, and public service of tomorrow, ${ }^{209}$ StudIoT (no longer operating), ${ }^{210}$ The Centre of Excellence in Next Generation Networking (CENGN) (a consortium of telecommunications firms to accelerate the growth of the Canadian ICT sector), and Startup Weekend UOttawa (an annual event where innovators and entrepreneurs pitch ideas they have for a start up to a set of judges for feedback and a chance to win prizes $\left.^{211}\right)$.

In addition to these projects, Ottawa has hosted a variety of smart city events. Academics, city employees, politicians, and the CEOs of smart city vendor firms are among attendees at these events. These events ${ }^{212}$ are open to the public, but some include a fee for entry. Ottawa smart city events include themes such as IoT, autonomous and electric vehicles, Hydro Ottawa's smart meters, LED lighting, 5G networks, and cyber security issues.

\footnotetext{
${ }^{205}$ http://www.canadiangreentech.ca/index.php/technology/smart-tech/4766-ottawa-leveraging-communicationstechnologies-in-connected-water-project

206 https://www.cantechletter.com/2016/11/city-ottawa-unveils-connected-water-quality-testing-pilot-rogersericsson/

${ }^{207}$ http://www.ic.gc.ca/app/ccc/srch/nvgt.do?app=sold\&profileId=1921\&prtl=1\&estblmntNo=234567135031\&profil $\mathrm{e}=$ cmpltPrfl\&lang=eng

208 http://cenx.com/company/overview/

${ }^{209}$ http://www.spring2innovation.com/

$210 \mathrm{https}: / /$ twitter.com/studiotehub

211 http://communities.techstars.com/canada/ottawa-gatineau/startup-weekend/11011

212 "En route to a Smart City". National Capital Commission. The Capital Urbanism Lab (webpage). Modified October 24, 2016. http://www.ncc-ccn.gc.ca/about-ncc/capital-urbanism-lab/calendar-events/en-route-to-a-smartcity: "Smart Cities: Imagining the future National Capital Region," Conference Agenda. Accessed March 14, 2017. http://www.bac-lac.gc.ca/eng/about-us/events/Documents/Smart-cities-agenda.pdf: "Cyber Security 2017: Securing the Smart City of the Future," Invest Ottawa (community events page). Accessed March 14, 2017. https://www.investottawa.ca/event/cyber-security-2017-securing-smart-city-future/.
} 
The city has invested millions of dollars in providing state of the art telecommunication equipment for the Innovation Centre at Bayview Yards. ${ }^{213}$ The center supports the development and the bringing to market products and services offered by technology companies. CENGN, a consortium of telecommunications firms, provided the Centre with its telecommunications equipment. In addition, Ottawa's Innovation Pilot Program supports local tech startups and technology firms test and commercialize their project in an urban setting (more information about this program is provided in Section 3.4.4).

\subsubsection{Technology Roadmap}

Finally, the City of Ottawa Technology Roadmap 2013-2016 provides plans and recent activities related to information security considerations, the GIS Enterprise, the Citizen Services Management (CSM) technology platform, IT performance management, IT infrastructure, and information technology services (ITS) principles and key performance indicators. The CSM is integrated with My ServiceOttawa, an account-based service provided by the municipality that allows Ottawa residents to securely access multiple City services and information online, in one place and using a single email address and password. ${ }^{214}$ In addition, one ITS principle listed in the Technology Roadmap is to evolve "a standards-based technology architecture that is integrated with City businesses, enabling cost-effective evolution of services and infrastructure and connectivity with City residents and business partners". ${ }^{215}$ However, the roadmap does not mention smart city mechanisms and devices such as IoT, sensors, interoperability standards, nor open data.

\subsubsection{Governance}

According to the Strategy, the Economic Development in the Long Range Planning, Infrastructure, and Economic Development Department will lead collaborative efforts with smart city stakeholders for the development and implementation of external facing smart city initiatives. Service Transformation of the Service Innovation and Performance Department will lead the development and delivery of the Digital Service Strategy component of Smart City 2.0. ${ }^{216}$ The city's open data team contributes to the smart city as a part of the team focused on the forthcoming Digital Services Strategy (DSS). Staff at Economic Development and Long Range Planning and Service Transformation plans to establish a Smart City 2.0 Working Group that will include representatives from Ottawa's smart city eco-system, like post-secondary institutions, residents, and knowledge-based businesses. The Group will serve in an advisory capacity to the city, Invest Ottawa, and Hydro Ottawa to ensure that the implementation of technology included within Smart City 2.0 meets the needs of Ottawa.

Currently, there is no official plan regarding who will be a part of operationalizing Ottawa's smart city initiative, or if there will be a full time dedicated smart city unit. The role of the privacy officer

\footnotetext{
${ }^{213}$ Sali, David. "New \$10M Innovation Centre lab to help Ottawa startups test loT, smart city tech," Ottawa Business Journal. Modified December 7, 2016. http://www.obj.ca/Technology/2016-12-07/article-4700159/New$\$ 10 \mathrm{M}-$ Innovation-Centre-lab-to-help-Ottawa-startups-test-IoT,-smart-city-tech/1.

214 https://myservice.ottawa.ca/about

215 http://app05.ottawa.ca/sirepub/cache/2/dyw4sb2t5bweoq0hr5bgvuhz/6303510062017120209559.PDF

216 Smart City 2.0. Submitted to the Finance and Economic Development Committee. City of Ottawa. November 2017. http://app05.ottawa.ca/sirepub/cache/2/dyw4sb2t5bweoq0hr5bgvuhz/4851211106201709281159.PDF.
} 
also does not appear to be part of the smart city governance structure, but is expected to be addressed in the forthcoming action plan. A governance model for Ottawa' smart city initiative will be included in the forthcoming smart city action plan.

\subsubsection{Procurement}

The Smart City 2.0 is not prescriptive on the topic of procurement; however, it does lean toward more flexible approaches and suggests "studying various global smart city procurement models where the private sector is asked to propose innovative solutions to city problems rather than responding to traditional requests for proposals". ${ }^{217}$ The upcoming smart city action plan is expected to provide more details about procurement models as well as standards, performance metrics, and inclusive stakeholder processes.

The Innovation Pilot Program is part of Smart City 2.0 and the city's Economic Development Strategy. The program supports technology startups for the testing and commercialization of innovative technologies. For instance, as part of this program, Ottawa has conducted a mobile gamification pilot approach as part of a staff mental health awareness training course, tested a collaboration platform to manage the Innovation Pilot Program applicant intake and review process, piloted social media monitoring capabilities and an e-signature solution, and the program is considering piloting a smart playground system that may use a combination of free-to-play mobile games in conjunction with a series of durable augmented reality markers affixed to specific pieces of playground equipment. There is also consideration for an audit compliance system, a connected and real-time monitoring water system, products for emergency exercises (Building Tactical Information System ${ }^{\mathrm{TM}}$ and Plan Ahead ${ }^{\mathrm{TM}}$ ), and other projects. ${ }^{218}$ The Innovation Pilot Program does not necessarily provide funding to these technology startups, but does aim to provide an opportunity to test new technology in an urban setting. ${ }^{219}$ The Strategy also includes the Innovation Centre at Bayview Yards as an incubator for emergent smart technology and services. The Economic Planning and Development group are tasked with advancing these smart economy initiatives, including the innovation component of Ottawa's smart city plans.

Concurrently, Ottawa's most recent economic development strategy, entitled Partnerships for Innovation: Economic Development Strategy Update, ${ }^{220}$ suggests that there is a lack of incubators and accelerators to stimulate Ottawa's innovation sector. This economic development strategy focusses on the need for knowledge-based investment to attract and create innovative businesses to meet Smart City 2.0's smart economy goal.

\footnotetext{
217 Smart City 2.0. Submitted to the Finance and Economic Development Committee. City of Ottawa. November 2017. http://app05.ottawa.ca/sirepub/cache/2/dyw4sb2t5bweoq0hr5bgvuhz/4851211106201709281159.PDF.

218 http://ottawa.ca/en/business/business-resources/economic-development-initiatives/innovation-pilot-program

219 "Innovation Pilot Program," City of Ottawa, accessed March 14, 2017. http://ottawa.ca/en/business/businessresources/economic-development-initiatives/innovation-pilot-program.

${ }^{220}$ http://app05.ottawa.ca/sirepub/cache/2/dyw4sb2t5bweoq0hr5bgvuhz/28701811222017045658444.PDF
} 


\subsubsection{Openness}

It is not clear how Ottawa's Accountability and Transparency Policy ${ }^{221}$ or the Routine Disclosure and Active Dissemination Policy ${ }^{222}$ will map on to Smart City 2.0. Digital inclusivity and literacy and open data are, however, part of the Strategy, yet many important 'open' components of a smart city, such as open standards/APIs, open science, open source, open algorithms/analytics, open licenses and data access, standards for ensuring transparency, privacy and security in regard to PII, and meaningful civic technology community contributions, are not mentioned in the Strategy.

Nonetheless, Ottawa does host one of the earliest CKAN Open Data Catalogues in Canada, ${ }^{223}$ and it has adopted for their open data an Open Data License 2.0..$^{224}$ The license provides the data free of charge and supports data re-users to "copy, modify, publish, translate, adapt, distribute or otherwise use the Information in any medium, mode or format for any lawful purpose". 225

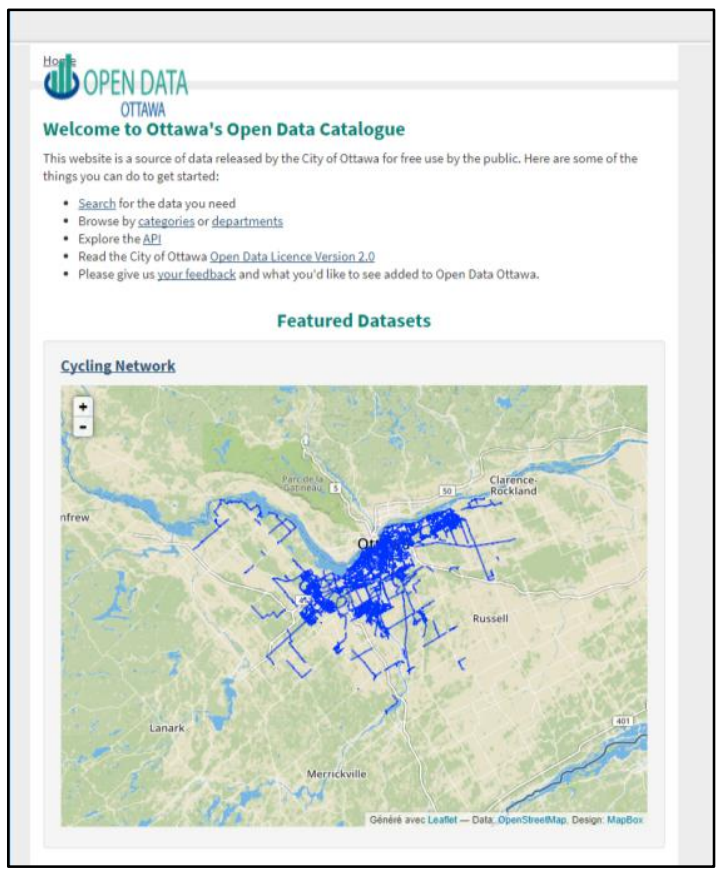

Figure 24 -Snapshot of Ottawa's Open Data Catalogue (Source: http://data.ottawa.ca/)

Third party developers currently do contribute to the re-purposing of City data and provide digital services to residents. For example, Flybits Inc. provides a location-based services (LBS) application that delivers open data about traffic incidents to its users. ${ }^{226}$ The application, titled Ottawa Nav, helps commuters access real-time traffic incident information, geospatial information about school and construction zones, and sensor data from live traffic camera feeds. Ottawa, like other cities assessed in the report, encourages developers to create open data applications by hosting regular hackathons. ${ }^{227}$ The municipality is also considering releasing real-time water consumption data as open data, and it provides 311 service request data on the open data catalogue.

\subsubsection{Citizen Engagement}

According to the Strategy, "residents, community groups, and businesses are best positioned to recommend and help develop digital solutions for the city". Smart City 2.0 specifies continuous engagement as part of its Continuous Engagement component which incorporates the following:

\footnotetext{
${ }^{221} \mathrm{https}: / /$ ottawa.ca/en/city-hall/accountability-and-transparency

${ }^{222}$ http://app05.ottawa.ca/sirepub/cache/2/dyw4sb2t5bweoq0hr5bgvuhz/7290811072017102741347.PDF

223"Ottawa's Open Data Catalogue," accessed March 14, 2017. http://data.ottawa.ca/.

224 "Innovation Pilot Program," City of Ottawa, accessed March 14, 2017. http://ottawa.ca/en/business/businessresources/economic-development-initiatives/innovation-pilot-program.

${ }^{225} \mathrm{http} / / /$ ottawa.ca/en/city-hall/get-know-your-city/open-data\#topen-data-licence-version-2-0

226 "Ottawa Nav," City of Ottawa, accessed March 14, 2017. http://ottawa.ca/en/residents/transportation-andparking/traffic.

${ }^{227}$ http://www.ottawacommunitynews.com/news-story/3813316-city-hall-hosts-hackathon-/
} 
1) Hackathons; 2) Meet Up Mondays at Bayview (attended by tech-communities like Open Data Ottawa, Ottawa Civic Tech, and Machine Learning Ottawa); 3) the development of a Smart City 2.0 website and engagement tools to inform residents and businesses with the ability to submit smart city ideas, and 4) Key Performance Indicator (KPI) Framework and dashboard so that the government and its smart city eco-system partners can assess the success of Smart City 2.0.

As previously stated, public officials held invitation-only smart city consultations about the development of its strategy, with invitations extending across sectors of government, industry, local business, post-secondary institutions and civil society organizations (e.g., Ottawa Community Foundation, Ottawa Community Housing, and Ottawa Impact Hub).

The city's Public Engagement Strategy ${ }^{228}$ includes principles and definitions on how to consult with the public and has developed a Public Engagement Toolkit ${ }^{229}$ for city staff. The toolkit provides a "common and consistent approach to public engagement across City of Ottawa departments". ${ }^{229}$ It is unclear if this toolkit informed Smart City 2.0 consultations.

In general, City Standing Committees are required to consult stakeholders and make their decisions public before moving on with the agenda. In addition, any decision by Council is subject to scrutiny by the public and goes through a committee that provides a public forum. The city also publishes documentation about public engagement events online. Before November 2017, when the Strategy was presented to Council, there had been limited press, social media, and/or blog posts soliciting input from the public on Smart City 2.0.

\subsubsection{Deployment of Geospatial and ICT Data}

As part of Smart City 2.0, the city plans to (1) expand sensor deployments; (2) develop a LED lighting enhancement test corridor to demonstrate advanced LED light technologies with roadway sensors, parking cameras, lighting control, and wireless capacity; and (3) advance Ottawa's leading position in data analytics by leveraging City data. The Strategy refers to IoT, big data, predictive analytics, and machine learning, yet it does not discuss standardized procedures for deploying these types of technologies, nor does it specify guiding principles on how to deploy these.

Like other cities included in this report, the Strategy does not mention geo-enabled or geovisualization, GIS, nor spatial planning methods and approaches.

The city has, however, recently updated its corporate spatial data repository with an ESRI and ArcGIS Server ${ }^{230}$. The IT-GIS group at the City of Ottawa provides the geospatial infrastructure, framework, and tools to support City business requirements. Data custodians oversee the data's management and publication and are responsible for data quality. The ArcGIS Server system update provides a single source of the most up to date data, business requirements to determine

\footnotetext{
228 http://ottawa.ca/en/city-hall/public-consultations/public-engagement

${ }^{229} \mathrm{http}$ ://ottwatch.ca/meetings/file/273915/Document_2_EN_Public_Engagement_Guidelines_and_Toolkit_pdf_Ite m_COMMUNITY_AND_SOCIAL_SERVICES_DEPARTMENT_IMPLEMENTATION_OF_PUBLIC_ENGAGE MENT_STRATEGY_Meeting_Community_and_Protective_Services_Committee_Date_2015_02_19_09_30_00

${ }^{230} \mathrm{https} / / /$ esri.ca/sites/default/files/filemanager/Training_and_Events/Conference_Proceedings/2012/Ottawa/Luken_ Barney_10_23_12.pdf
} 
automatic movement of data, the reduction of data duplication, the implementation of metadata standards, and commercially off the shelf (COTS) solutions technologies. Other applications reliant on the new ArcGIS and Esri Server systems are also being upgraded via COTS that provide for web services. Specifically, the 311 Service Request system will be upgraded via the Lagan technology services and asset management via the Maximo software solution products produced by IBM. ${ }^{230}$ Permit/license applications processes will also undergo upgrades. ${ }^{230}$ The upgraded environment positions geoOttawa as the city's public facing map for the geo-visualization of open data. The city plans to update open data via the ArcGIS and ESRI Server automatically. Business units geocode a variety of government data, such as building permit application data, traffic activity data, and development activity data.

geoOttawa is an online public facing map that includes geo-enabled City zoning, historical air photos, and remote aerial sensing images. City staff is working on making geoOttawa more accessible by creating a geoOttawa lite version that will be readily accessible on all major browsers and devices (i.e., tablets and smart phones), and to deploy screen readers, speech recognition services, and keyboard navigation. Data presented in geoOttawa is posted to the Ottawa Open Data catalogue as machine-readable datasets.

The City of Ottawa, like other cities assessed in this report, publishes geospatial data openly on their open data catalogue. ${ }^{231}$ These geo-enabled data include Ottawa's trails, water bodies, location of public facilities, and ward boundaries and are stored in a variety of machine-readable (SHP, KMZ, GeoJSON, dwg, CSV, XML, XLS, and PNG) and human-readable formats. Geo-enabled traffic incident sensor derived data and zoning have been repurposed into a multimodal third party commuting application entitled Ottawa Nav.

In addition to the GeoOttawa map, the government publicly provides other mapping services. ${ }^{232}$ For example, In My Neighborhood ${ }^{233}$ is a bilingual interactive map of Ottawa that helps residents locate schools, libraries, parks, recreation facilities, community services, events, land development applications, and more. ${ }^{234}$ In My Neighborhood leverages the ArcGIS My Government Services Local Government ${ }^{235}$ template. Ottawa also publishes maps containing information about how to find out if your house is in the 1-in-100-year flood plain, ${ }^{236}$ an online map of public and portable washrooms in City of Ottawa Facilities and Parks, ${ }^{237}$ Heritage Conservation Districts Map, ${ }^{238}$ and a Water Quality in Ottawa's Rivers, Lakes and Streams map. Water quality data are visualized according to the Water Quality in Ottawa's Rivers, Lakes, and Streams map, and is evaluated against three sets of criteria - the Provincial Water Quality Objectives, the Canadian Water Quality Guidelines for the Protection of Aquatic Life, and the Canadian Council of Ministers of the

231 http://data.ottawa.ca/group/geography-and-maps

232 http://ottawa.ca/en/city-hall/get-know-your-city/maps-ottawa\#heritage-conservation-districts

233 http://maps.ottawa.ca/imn/desktop.htm

$234 \mathrm{http} / / /$ ottawa.ca/en/city-hall/get-know-your-city/maps-ottawa\#my-neighbourhood

235 https://www.arcgis.com/home/item.html?id=23c7fd011b64434d87fb0aa607f2c049

$236 \mathrm{http}$ ://ottawa.ca/en/city-hall/get-know-your-city/maps-ottawa\#my-neighbourhood

237 http://ottawa.ca/en/city-hall/get-know-your-city/maps-ottawa\#my-neighbourhood

238 http://ottawa.maps.arcgis.com/apps/MapJournal/index.html?appid=2306b490ff9f46f7a0b2f467a9bc2499 
Environment Water Quality Index. ${ }^{239}$ "Raw" water quality data visualized in these maps are provided in CSV file formats on the Ottawa Open Data Catalogue.

Other emerging smart and geospatial activities include the test tracking of autonomous vehicles and government's deployment of remote sensing technologies to assess the performance of city infrastructure. City staff have also test tracked autonomous vehicles by setting up bay stations to rebroadcast GPS locations. In addition, the GIS and Data Services Group is responsible for the daily maintenance of both the water distribution and sanitary and storm collection systems. City staff makes the data collected for maintenance purposes, planning and renewal available via Citywide Index Maps of the Water Distribution System and the Sanitary and Storm Collection Systems. ${ }^{240}$ Ottawa's Surveys and Mapping Group provides land information expertise and vital geographic data to support internal operations by business units and external client needs. Services by the Surveys and Mapping Group include procuring, maintaining and distributing essential geographic data by using specialized applications.

While the strategy specifies that the deployment of sensors and actionable data are a part of Smart City 2.0, specifics outlining how the city will manage data derived from these devices are not yet determined. Currently, there is no centralized location to store City data. The Digital Services Strategy, which is expected to be released for the first quarter of 2018, will focus on how to centrally store data from various business units and consider an analytical process to optimally extract meaning from the data.

In terms of IP, the legal department recommends that data use licenses be negotiated before any data are externally shared. Strategic methods to standardize, archive, and secure smart city data (i.e., at the sensor and device level) were not addressed in the strategy. It is anticipated that the forthcoming action plan will provide insight about preferred methods and standards about secure data practices, quality and interoperability.

\subsubsection{Summary and Observations}

The City of Ottawa is in the very early stages of implementing is smart city plans. Responsibility for the smart city has shifted over time from the IT Subcommittee to FEDC, a powerful crossdepartmental City standing committee. As is discussed and summarized in Table 9 below, the City of Ottawa recently released its smart city vision and roadmap in alignment with Council priorities, and it aims to advance Ottawa as a smart organization. The perceived benefits of Ottawa's smart city strategy include better access to information by the general public, improved City services, and attraction of talent and competitive businesses within the global economy. Ottawa is unique in that its smart city strategy includes precision agriculture and its benefits are expected to extend to rural areas.

That said, smart city plans have not been open and transparent to the public. The focus on attracting input from experts and business has resulted in invitation-only events. It is hoped that Ottawa will

\footnotetext{
${ }^{239}$ http://ottawa.ca/en/city-hall/get-know-your-city/maps-ottawa

240 http://ottawa.ca/en/business/planning-and-development/engineering-services
} 
develop a governance structure that empowers and invites a more balanced and diverse set of stakeholders to set focus areas and make decisions regarding the smart city.

In addition, Ottawa's overall city vision is guided by principles of government accountability, open and participatory processes, public awareness, and access to quality information. We await to see how Smart City 2.0 will ensure that these principles are upheld. For the moment, smart city actors have not specified the principles that guide them to achieve their smart city goals of connectivity, innovative government, and smart economy. Guiding considerations for IT procurement are not discussed, nor is the practice of negotiating control and access of smart data, software, data standards, etc.

The forthcoming action plan may address some of these gaps. Like the other cities included in this report, it is hoped that the smart city will include approaches to ultimately improve the social, economic and general well-being of all Ottawa residents and their environment, and that data and technology will protect personal privacy while enabling residents, civil society and the private sector to play a meaningful part in reinforcing an ethical, engaged, collectively owned, and secure smart city.

Table 9 - Summary of the City of Ottawa Smart City Initiative

\begin{tabular}{|c|l|c|}
\hline $\begin{array}{c}\text { Smart City } \\
\text { Component/Process }\end{array}$ & \multicolumn{1}{c|}{ Current State } \\
\hline $\begin{array}{c}\text { Smart City Strategy/ } \\
\text { Roadmap }\end{array}$ & Smart City 2.0 (2017) & $\begin{array}{c}\text { Considerations for the } \\
\text { Future }\end{array}$ \\
\hline $\begin{array}{c}\text { Action Plan \& Guiding } \\
\text { Principles }\end{array}$ & $\begin{array}{l}\text { Action Plan is forthcoming and will } \\
\text { include: prioritization of smart city } \\
\text { governance model, KPI framework, } \\
\text { and the development of a web- } \\
\text { presence, digital platform and } \\
\text { forums to actively engage residents, } \\
\text { businesses, and smart city partners; } \\
\text { Guiding principles have not been } \\
\text { specified for the smart city. }\end{array}$ & Forthcoming \\
\hline Urban Plan & $\begin{array}{l}\text { Smart City 2.0 vision and goals will } \\
\text { be embedded in the City's Official } \\
\text { Plan, Transportation Master Plan, } \\
\text { and Asset Management Strategy as } \\
\text { they are updated. }\end{array}$ & $\begin{array}{c}\text { How will the relevant } \\
\text { plans and strategy } \\
\text { integrate and mandate } \\
\text { the implementation of } \\
\text { smart city technologies? }\end{array}$ \\
\hline
\end{tabular}




\begin{tabular}{|c|c|c|}
\hline Governance Structure & $\begin{array}{l}\text { The Economic Development and } \\
\text { Long Range Planning and Service } \\
\text { Transformation team will lead and } \\
\text { work with Invest Ottawa and Hydro } \\
\text { Ottawa on the Smart City Working } \\
\text { Group; A smart city governance } \\
\text { model will be part of the } \\
\text { forthcoming smart city action plan. }\end{array}$ & $\begin{array}{l}\text { How will residents be } \\
\text { represented in the } \\
\text { governance structure for } \\
\text { the smart city? Will } \\
\text { citizens have a decision- } \\
\text { making role and be } \\
\text { empowered to be } \\
\text { critically engaged and } \\
\text { assess smart city } \\
\text { developments? What } \\
\text { role will civic } \\
\text { technology and civil } \\
\text { society groups play in } \\
\text { the development of } \\
\text { Smart City 2.0? }\end{array}$ \\
\hline Dedicated Personnel & Not yet. & $\begin{array}{l}\text { Will there be dedicated } \\
\text { legal, privacy and } \\
\text { security } \\
\text { personnel/function? }\end{array}$ \\
\hline Dedicated Unit & Not yet. & $\begin{array}{c}\text { Will there be dedicated } \\
\text { legal, privacy and } \\
\text { security } \\
\text { personnel/function? }\end{array}$ \\
\hline Inventory of initiatives & $\begin{array}{l}\text { Not yet; But there has been an ad- } \\
\text { hoc compilation of smart initiatives } \\
\text { and projects by city staff; Ottawa } \\
\text { has not yet settled on a smart city } \\
\text { definition. }\end{array}$ & $\begin{array}{l}\text { What constitutes a smart } \\
\text { city program/project? } \\
\text { What is systematic about } \\
\text { this decision process? }\end{array}$ \\
\hline Procurement & $\begin{array}{l}\text { The strategy includes studying new } \\
\text { procurement models; Ottawa has an } \\
\text { Innovation Pilot Program and } \\
\text { Innovation Centre at Bayview } \\
\text { Yards to enable the municipality to } \\
\text { partner with businesses and pilot } \\
\text { innovative services and products; } \\
\text { The CENGN is a consortium of } \\
\text { telecommunications companies that } \\
\text { partner with Invest Ottawa to } \\
\text { accelerate innovation in ICT sector. }\end{array}$ & $\begin{array}{l}\text { What will the guiding } \\
\text { principles, standards, } \\
\text { open source, and etc., be } \\
\text { for procuring smart city } \\
\text { technologies? Will open } \\
\text { source, open standards, } \\
\text { privacy and transparency } \\
\text { by design, and } \\
\text { cybersecurity standards } \\
\text { guide requests for } \\
\text { proposals? Will the city } \\
\text { retain data, hardware and } \\
\text { software IP? }\end{array}$ \\
\hline
\end{tabular}




\begin{tabular}{|c|c|c|}
\hline Engagement & $\begin{array}{l}\text { Two invitation only consultations } \\
\text { with representatives from } \\
\text { businesses, civil society } \\
\text { organizations, post-secondary } \\
\text { institutions, and public } \\
\text { representatives about the strategy; } \\
\text { The general public was not } \\
\text { consulted directly (via } \\
\text { crowdsourcing mechanisms, social } \\
\text { media, open forums) in formulating } \\
\text { and determining priorities for the } \\
\text { strategy; Outputs and records of } \\
\text { consultations and research that } \\
\text { informed the strategy are not made } \\
\text { easily available to the public; There } \\
\text { is limited social media outreach; No } \\
\text { indication of residents being } \\
\text { incorporated in a decision-making } \\
\text { capacity; Ottawa has a citywide } \\
\text { public engagement strategy, toolkit } \\
\text { and event inventory but it is not } \\
\text { overtly linked to the development of } \\
\text { Smart City } 2.0 \text {; FEDC and Council } \\
\text { meetings to pass the smart city } \\
\text { strategy were open to the public; } \\
\text { Smart City } 2.0 \text { is made public } \\
\text { online. }\end{array}$ & $\begin{array}{l}\text { How will smart } \\
\text { citizens/residents be } \\
\text { empowered and included } \\
\text { in a decision making } \\
\text { capacity? Will residents } \\
\text { and civil sociey } \\
\text { organizations co-create } \\
\text { the smart city action } \\
\text { plan? If yes, what } \\
\text { methods will be } \\
\text { deployed to enable co- } \\
\text { creation of smart city } \\
\text { services? }\end{array}$ \\
\hline Openness & $\begin{array}{l}\text { Open data is part of the innovative } \\
\text { government goal; There is an Open } \\
\text { Data Catalogue that implements } \\
\text { open data formats, open maps and } \\
\text { web mapping services, an open } \\
\text { license, and the CKAN open source } \\
\text { platform; There are no specific } \\
\text { plans for public engagement beyond } \\
\text { open data hackathons and meet ups. }\end{array}$ & $\begin{array}{l}\text { Will an overall open } \\
\text { source strategy be part of } \\
\text { the smart city? Will open } \\
\text { standards be considered } \\
\text { for the smart city and } \\
\text { IoT? }\end{array}$ \\
\hline Spatial Data & $\begin{array}{l}\text { GIS and geospatial data are not } \\
\text { mentioned in the Strategy; Staff } \\
\text { deploy geoOttawa map, real-time } \\
\text { traffic services, ESRI and ArcGIS } \\
\text { Server, autonomous vehicle testing; } \\
\text { GIS and Data Services and Survey }\end{array}$ & $\begin{array}{l}\text { How will Ottawa } \\
\text { utlimately decide on the } \\
\text { adoption or rejection of } \\
\text { standards for integrating } \\
\text { geospatial data? How } \\
\text { will data be geocoded? }\end{array}$ \\
\hline
\end{tabular}




\begin{tabular}{|c|c|c|}
\hline & $\begin{array}{l}\text { and Mapping Groups use geospatial } \\
\text { data for City operations. }\end{array}$ & $\begin{array}{l}\text { How will groups that } \\
\text { specialize in GIS and } \\
\text { mapping contribute and } \\
\text { be incorporated into the } \\
\text { smart city strategy? }\end{array}$ \\
\hline Crowdsourcing & $\begin{array}{l}\text { Ottawa public works uses the } \\
\text { Open311 standard for service } \\
\text { request open data. }\end{array}$ & $\begin{array}{l}\text { What role will } \\
\text { crowdsourcing data play } \\
\text { in the smart city? }\end{array}$ \\
\hline \multirow{2}{*}{$\begin{array}{c}\text { Standards \& } \\
\text { Interoperability }\end{array}$} & $\begin{array}{l}\text { Standards are not mentioned in the } \\
\text { strategy; Metadata standards are } \\
\text { specified by the ArcGIS and ESRI } \\
\text { Server; Ottawa uses CKAN open } \\
\text { data platform and Open311 API. }\end{array}$ & \multirow{2}{*}{$\begin{array}{c}\text { How will the } \\
\text { forthcoming Digital } \\
\text { Services Strategy } \\
\text { approach data } \\
\text { interoperability and } \\
\text { integration? Will } \\
\text { interoperability of } \\
\text { software and data be } \\
\text { specified and will the } \\
\text { smart city be a platform } \\
\text { that others plug into? }\end{array}$} \\
\hline & $\begin{array}{l}\text { No mention of mapping } \\
\text { interoperability needs in Smart City } \\
\text { 2.0. }\end{array}$ & \\
\hline Privacy & $\begin{array}{l}\text { No mention of privacy } \\
\text { considerations in smart city } \\
\text { strategy; Government adheres to } \\
\text { principles outlined in the Municipal } \\
\text { Freedom of Information and } \\
\text { Protection of Privacy Act } \\
\text { (MFIPPA); } \\
\text { The municipal Access to } \\
\text { Information and Privacy Office is } \\
\text { consulted on a regular basis to } \\
\text { provide advice to staff regarding the } \\
\text { collection, use, disclosure, retention } \\
\text { and disposal of personal } \\
\text { information. }\end{array}$ & $\begin{array}{l}\text { Will privacy by design } \\
\text { principles be applied to } \\
\text { smart city technologies? } \\
\text { How has and will the } \\
\text { Access to Information } \\
\text { and Privacy Office } \\
\text { contribute their expertise } \\
\text { to the planning and roll } \\
\text { out of Smart City 2.0? }\end{array}$ \\
\hline
\end{tabular}




\begin{tabular}{|c|l|c|}
\hline Security & $\begin{array}{l}\text { Smart City 2.0 does not mention } \\
\text { security issues and it was not } \\
\text { discussed in interview; The } \\
\text { Technology Roadmap addresses } \\
\text { information security citywide. }\end{array}$ & $\begin{array}{c}\text { What security standards } \\
\text { and practices will be } \\
\text { applied in a smart city } \\
\text { context, such as for data } \\
\text { captured by meters and } \\
\text { sensors and at the device } \\
\text { level? }\end{array}$ \\
\hline Archiving & $\begin{array}{l}\text { Smart City 2.0 does not mention } \\
\text { archiving considerations for data; } \\
\text { Archiving practices were not } \\
\text { discussed with city representatives. }\end{array}$ & $\begin{array}{c}\text { How will data } \\
\text { preservation be } \\
\text { considered for emergent } \\
\text { smart city technologies, } \\
\text { especially IoT and SaaS? }\end{array}$ \\
\hline
\end{tabular}




\section{Inter-jurisdictional Results}

\subsection{Ontario Smart Grid}

The Province of Ontario is responsible for a range of smart energy initiatives in cities and rural areas, as well as projects that promote and deploy data driven and networked technology throughout province. Smart energy grid technologies and utilities are governed by regulation legislation, polices, a number of agencies, and stakeholders. For example, the Ministry of Energy has province wide Long Term Energy Plans, ${ }^{241}$ and cities via their local distribution companies operationalize part of that plan. The Electricity Act, $1998^{242}$ defines a Smart Grid as follows:

(1.3) For the purposes of this Act, the smart grid means the advanced information exchange systems and equipment that when utilized together improve the flexibility, security, reliability, efficiency and safety of the integrated power system and distribution systems, particularly for the purposes of,

(a) enabling the increased use of renewable energy sources and technology, including generation facilities connected to the distribution system;

(b) expanding opportunities to provide demand response, price information and load control to electricity customers;

(c) accommodating the use of emerging, innovative and energy saving technologies and system control applications; or

(d) supporting other objectives that may be prescribed by regulation. 2009, c. 12, Sched. B, s. 1 (5).

Overall there are three defining and fundamental components that make a grid system smart and modern:

(1) sensors connected to the distribution system that are able to collect digital information on the health of the system and its operational status,

(2) the communication infrastructure that transmits energy use data to a central warehouse, and

(3) a software platform that is able to collect and analyze data and provide certain outputs, including information to make annual decisions.

\subsubsection{Smart Metering Initiative}

The Ontario smart metering system utilizes an Advanced Metering Infrastructure (AMI) to transfer information via two-way communication protocols (see Figure 25) and is one of the components of a smart grid. AMI comprises of smart electricity meters, a communication network, a meter data management system, and utility operational software for billing customers, the generation of distribution efficiencies. ${ }^{243}$ In Ontario, smart meter technology tracks energy use in the home on

\footnotetext{
241 https://www.ontario.ca/page/ontarios-long-term-energy-plan

${ }^{242}$ Electricity Act, 1998, S.O. 1998, CHAPTER 15, Schedule A, section 1.3. https://www.ontario.ca/laws/statute/98e15.
} 
an hourly basis and sends this information back to the Local Distribution Company (LDC) that services and bills the customer. ${ }^{243}$ According to Toronto Hydro-Electric System Limited, smart metering acts as the "gateway" between the electricity grid and the consumer of energy. ${ }^{244}$

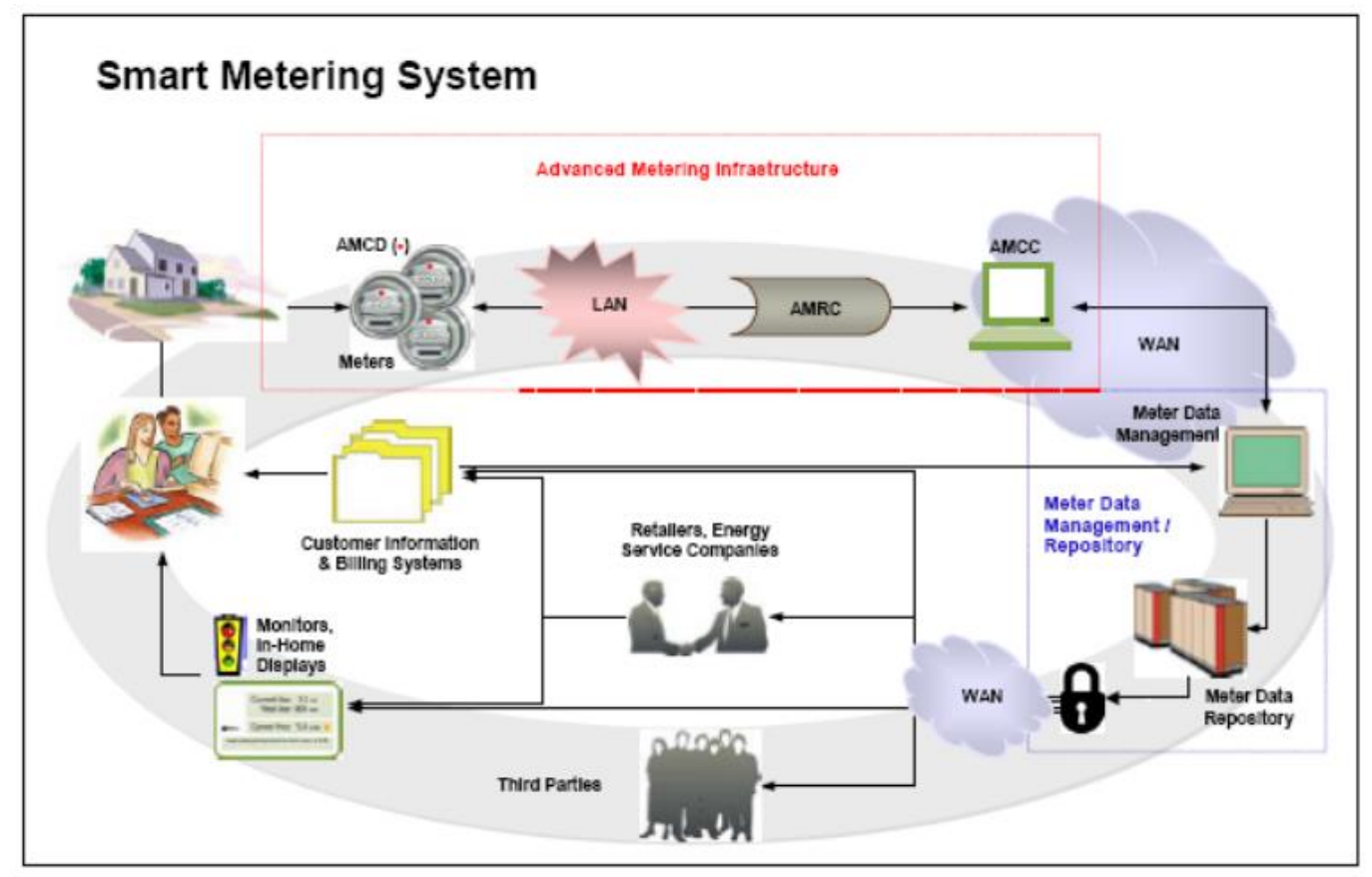

Figure 25 - Smart Metering System (Source: Government of Ontario IT Standard: Advanced Metering Infrastructure (2007) p. 5, https://dr6j45jk9xcmk.cloudfront.net/documents/1889/go-its-51advanced-metering-infrastructure.pdf)

In 2004, the Minister of Energy, under the Energy Board Act, 1998, directed the Ontario Energy Board (OEB) to propose an implementation plan for the installation of smart meters. The desire to deploy smart metering is said to reflect the intention of Ontario's Ministry of Energy to manage demand for electricity in Ontario so as to more efficiently use existing power-generating capacity in the province while reducing reliance on out-of-province power purchases. ${ }^{245}$ Ontario's Smart Meter Initiative set a target to install smart meter technology in all Ontario homes and businesses by 2010 .

Organizationally, the Smart Metering Initiative included the participation of the Ministry of Energy, OEB (the regulator of Ontario's natural gas and electricity utilities), Independent Electricity System Operator (IESO) (the not for profit corporate entity responsible for overseeing the electricity market and directing the operation of Ontario's electricity system), and over 70 local distribution centres or companies, including Hydro One (which services rural areas of the

\footnotetext{
${ }^{243}$ https://www.consumerscouncil.com/site/consumers council of canada/assets/pdf/SM Report.pdf

244 https://www.torontohydro.com/sites/electricsystem/Documents/2012EDR/G1_T01_S02.pdf

245 http://www.auditor.on.ca/en/content/annualreports/arreports/en14/311en14.pdf
} 
Province). As of December 31, 2017, approximately 4.9 million smart meters had been installed in homes and small businesses across Ontario ${ }^{246}$.

\subsubsection{Accessing Energy Use Data}

The Ministry of Energy and its agencies ${ }^{247}$ participated in and oversaw initiatives to share and open aggregated reports about the energy sector and energy use data with third parties. These initiatives include:

1. The Ontario Energy Report, an online portal that provides energy to consumers and stakeholders with an up-to-date snapshot of Ontario's energy sector;

2. Utility performance monitoring, a set of electricity utility dashboards; natural gas and electricity year books for financial, operations, and reliability data; and audits and assessment reviews published online by the Ontario Energy Board (OEB);

3. Smart Meter Entity: Third Party Access Implementation Plan (discussed below); and

4. The Green Button Initiative (discussed below).

\subsubsection{Smart Meter Entity: Enhancing Value of Meter Data and Third Party Access Implementation Plan}

Energy use data, once ingested and read by a meter, are partially de-identified by local distributors in Ontario (e.g., Ottawa Hydro and Guelph Hydro) and are transferred to Ontario's Independent Electricity System Operator (IESO) which is the Province's Smart Metering Entity (SME). The Electricity Act, 1998 designated the SME as the responsible entity for managing the Meter Data Management/Repository (MDM/R), which is the central repository for the province's meter data. The SME is also responsible for the verification process whereby energy use data are accurately converted into time of use data. These data are then transferred back to local distribution companies (LDCs) so they can bill a customer's energy consumption based on time of use.

In 2013, the OEB issued a Supplemental Report on the Smart Grid. ${ }^{248}$ In this report, the OEB stated that there was an opportunity for innovation by enhancing the value of meter data stored in the MDM/R. ${ }^{249}$ The OEB further recommended that the SME look into the possibility of providing the data for third party access in a way that did not compromise the security and privacy of customers that utilities service.

In 2014, MaRS Advanced Energy Centre (AEC) and the IESO launched consultations to examine the access rules for aggregated energy consumption data that could potentially be used for research and innovative product development. The initiative, entitled the Meter Data Access Project (MDAP), aimed to develop a business case to identify the benefits and costs associated with integrating additional data sets with existing meter data (see Figure 26). The platform considered integrating additional data (e.g., property, generation, commercial) with MDM/R data to create

\footnotetext{
${ }^{246}$ http://www.auditor.on.ca/en/content/annualreports/arreports/en16/v2 111en16.pdf

247 IESO, Hydro One, and OEB.

248 https://www.oeb.ca/oeb/ Documents/EB-2011-0004/Supplemental Report on Smart Grid 20130211.pdf

249 http://www.ieso.ca/Documents/consult/Foundation/Foundation-20151104-FoundationProject-Final-Report.pdf
} 
actionable insights for Ontario. The AEC and the IESO released their final advisory report on the MDAP in October of 2015.

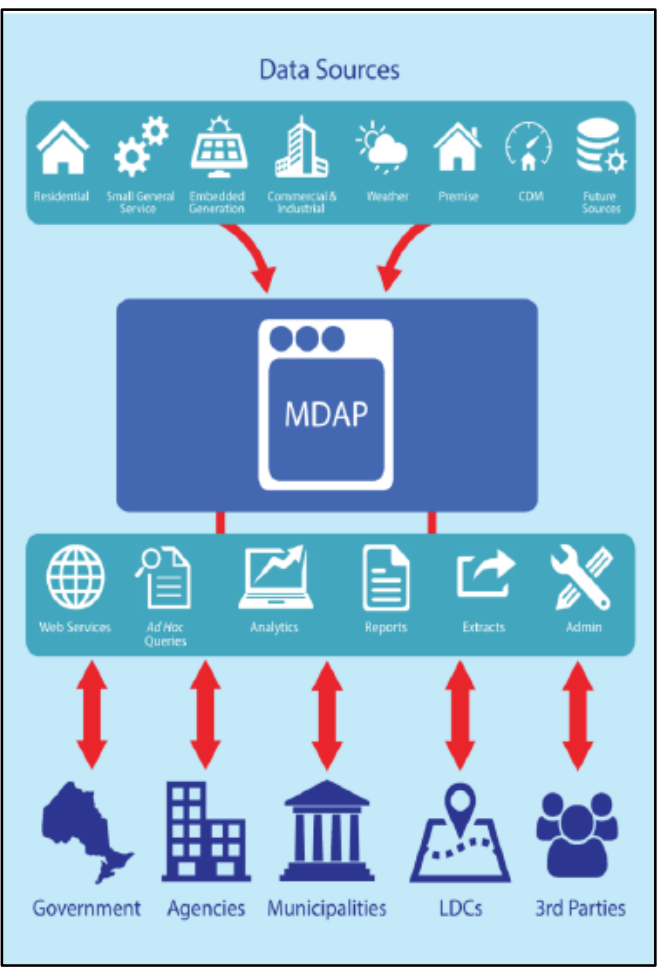

Figure 26 - MDAP Project (source: Third Party Access to MDM/R Data: Privacy Law Considerations (2017) p. 21, http://www.ieso.ca//media/files/ieso/documentlibrary/smart-meteringentity/dsac/dsac-20170802-privacylaw-presentation.pdf?la=en )
In March of 2015, the IESO established the Foundation Working Group (FWG) to lead the Foundation Project, the first initiative to enhance the value of meter data stored in the MDM/R with additional elements to enable access by third parties. Thus, the FWG was responsible for recommending (1) requirements to accurately complete the information in the MDM/R to enable the analysis of the data and (2) rules for third party access to enhanced energy use data. ${ }^{250}$ As a result, the FWG provided two frameworks in their Final Report: A Framework for Third Party Access and a Framework for De-Identification of Information for Disclosure to Third Parties. ${ }^{251}$ These two recommended frameworks were developed in close consultation with LDCs. The project's Final Report documents differences of opinions among FWG members regarding third party access to MDM/R data. For example, FWG members disagreed about whether certain government agencies should be able to access personally identifiable information (PII) collected by LDCs. Some LDCs were members of the FWG and did not support access by government agencies to PII. These LDCs cited that it was their responsibility to protect the privacy of their customers.

The Foundation Project's Final Report, released on November 4, 2015, did not include an implementation plan, noting that costs had not yet been assessed and, more importantly, that the recommendation to pair consumption information with addresses would raise privacy concerns. Thus, the Foundation Project's Final Report did not propose how (i.e., technical protocols) to enhance meter data for access by third parties in a way that protects personal privacy.

When the SME applied to renew their license with the OEB in November 13, 2015, the application failed to mention the Foundation Project's recommendations or how they could be implemented by the SME. In their response ${ }^{252}$ to the license renewal application, the OEB stated it felt that regulatory scrutiny was needed to increase the speed to enhance the value of the MDM/R data. Thus, the OEB renewed SME's license for a year (instead of five) and mandated via Order EB-2015-0297 that the

\footnotetext{
${ }^{250}$ www.ieso.ca/Documents/consult/Foundation/Foundation-20150422-Project Plan Overview.pdf

${ }^{251}$ http://www.ieso.ca/sector-participants/engagement-initiatives/engagements/completed/Lmedia/files/ieso/document-library/engage/foundation/Foundation-20151104-Foundation-Project-FinalReport.pdf

252 http://www.rds.oeb.ca/HPECMWebDrawer/Record/514364/File/document
} 
SME shall, effective January 1, 2017, collect the following information associated with each meter (modified where necessary to sufficiently render it non-personal information): the postal code, the distributor rate class, the commodity rate class, and occupant change data. Order EB-2015-0297 also required the SME to prepare and include in its next application to renew its license an implementation plan for third party access ${ }^{253}$.

\section{Part 1 - SME Response to OEB Order EB-2015-0297}

In response to the OEB Order EB-2015-0297, the IESO established the SME License Order Working Group (or Working Group) to set technical protocols for the collection of mandated data elements. The process to enhance data elements for $\mathrm{MDM} / \mathrm{R}$ data entailed extensive privacy impact and reidentification risk assessments. The Working Group consisted of representatives from the IESO (SME, Legal, and Regulatory), 13 LDCs, and 5 Observers from the Ministry of Energy, Electricity Distributors Association (EDA), OEB, and two gas utilities (i.e., Enbridge and Union Gas).

The Working Group conducted broad outreach with experts, stakeholders, and the general public. The Information Privacy Commissioner (IPC) for Ontario and an expert consultancy firm, Privacy Analytics Inc., conducted the duel-phase privacy assessment before and after data were enhanced in the MDM/R with geo-location elements.

Privacy Analytics, Inc. has worked with health care organizations and has supported others to comply with privacy by design third party data access for other public organizations, global standards and frameworks such as: Institute of Medicine (IOM), Health Information Trust Alliance (HITA), the Council of Canadian Academies, the Health Insurance Portability and Accountability Act (HIPAA), and the EU General Data Protection Regulation (EU GDPR) framework, and were designated by IESO as responsible for evaluating the risk of re-identification of the dataset containing newly mandated data elements and recommending any required changes to the MDM/R to protect the privacy of costumers. To do this, they implemented a conceptual re-identification risk determination methodology to evaluate risk of re-identification based on new data elements. One recommendation by the firm was for the LDC to mask street addresses before sending data to the centralized MDM/R. The SME accepted this recommendation. Additionally, the SME conducted an industry scan of third party data access practices and consulted with other organizations (e.g., Statistics Canada, The Canadian Institute for Health Information, Municipal Property Assessment Corporation) to learn about their data sharing processes.

The SME established a comprehensive dialogue with the following stakeholders: LDC Community, SME Steering Committee, and MDM/R Technical Panel Members. These stakeholders were communicated with via webinars, Electricity Distributors Association (EDA) communications, email notifications, in person meetings, and surveys. Communications were ongoing over time and documented by the SME. Finally, public facing communications about the Working Group's activities and decisions were shared via a webpage. The webpage provides the OEB Order, meeting agendas, formal presentations and meeting minutes.

Technical protocols to collect data elements that were determined to comply with the OEB Order and privacy legislation include:

- 6 digital postal code (unique dwelling postal codes masked by LDCs),

${ }^{253}$ http://www.rds.oeb.ca/HPECMWebDrawer/Record/514364/File/document 
- distributed and commodity rate classes,

- $\quad$ and occupant change date (generalized at yearly level) (see Table 10 for details). ${ }^{254}$

New data elements were integrated into the MDM/R via a new code that was piloted internally by the SME and then by the LDCs. MDM/R synchronization of additional data elements was stated to not impact the meter read data validation and estimation functionality or the billing functionality. The SME provided LDCs (once they started synchronizing new data elements) with data compliance reports in addition to the regular synchronization reports. These reports helped the LDCs to monitor their progress during the synchronization of new data elements into the MDM/R.

Ontario's meter data has been enhanced with new data elements by all of Ontario's licensed LDCs. Geo-enabled MDM/R data by postal code is consumed by ESRI's mapping and analytics ArcGIS platform.

Table 10 - Available Data Elements for Third Party Access (Source: The Third Party Access Implementation Plan (2016))

\begin{tabular}{|c|c|}
\hline Data Elements & Data Elements Description \\
\hline $\begin{array}{l}\text { Consumption Data (existing } \\
\text { data) }\end{array}$ & Hourly interval data, aggregated as required. \\
\hline $\begin{array}{l}\text { Location by Postal Code } \\
\text { (newly required by OEB } \\
\text { order) }\end{array}$ & $\begin{array}{l}\text { The Postal Code associated with the Service Delivery Point } \\
\text { (SDP), i.e. Service Location, where the meter is installed. For } \\
\text { Third Party requests, the level of generalization of the Postal } \\
\text { Code will be based on the risk of re-identification as it relates to } \\
\text { the data sample and the requestor's risk profile following a } \\
\text { consistent framework that will be developed in consultation } \\
\text { with the Privacy Consultant and the IPC. }\end{array}$ \\
\hline $\begin{array}{l}\text { Distributor Rate Class } \\
\text { (newly } \\
\text { required by OEB Order) }\end{array}$ & $\begin{array}{l}\text { The market segment to which the customer, associated to the } \\
\text { SDP, belongs. }\end{array}$ \\
\hline $\begin{array}{l}\text { Commodity Rate Class } \\
\text { (newly required by OEB } \\
\text { Order) }\end{array}$ & The price plan for the customer associated to the SDP. \\
\hline $\begin{array}{l}\text { Validation of Occupant } \\
\text { Status (newly required by } \\
\text { OEB order) }\end{array}$ & $\begin{array}{c}\text { The year associated with this parameter defines whether a } \\
\text { move-in/move-out event by the premise's occupant occurred in } \\
\text { the indicated year. }\end{array}$ \\
\hline
\end{tabular}

${ }^{254}$ http://www.ieso.ca/-/media/files/ieso/document-library/working-group/sme/sme-20170224presentation.pdf?la=en 


\begin{tabular}{|c|c|}
\hline Number of Premises & $\begin{array}{c}\text { Number of premises used to fulfill the data request. Data may } \\
\text { not be provided if a data request involves }<\mathrm{X} \text { (e.g. 5) number } \\
\text { of premises. }\end{array}$ \\
\hline
\end{tabular}

Part 2 - SME Response to OEB Order EB-2015-0297

Now that MDM/R data have been enhanced with additional data elements, the SME has turned their attention to planning the implementation of the Third Party Access Program. Before producing a formal implementation plan, the SME first devised a Framework for Third Party Access. This Framework consisted of guiding principles, a governance framework (compartmentalized by regulatory, legal, and external and internal governance structures), segmentation of requestors into risk categories (to determine the risk that the third party will attempt to re-identify the data), a high-level outline of the process for third party access, and metrics for measuring success. Guiding principles outlined in the framework are as follows: purpose and governance, no impact to core functions, operation effectiveness, data stewardship, and privacy by design as a core principle.

In terms of the Implementation Plan's internal governance structure, IESO has set up an Executive Steering Committee that includes members of the IESO executive leadership team and an executive sponsor of the program. In terms of an external governance structure for the Plan, the SME implements a two-pronged approach to external engagement. One approach is focused on having experts from variety of sectors advise throughout the process. Thus, SME has appointed, via an open call for nominations, the Data Strategy Advisory Council ${ }^{255}$ as the entity responsible for advising on the SME's plan to implement third party access to de-identified smart meter data. The City of Guelph and the County of Oxford are members of the Council. The Council also presented and reviewed the Roadmap for Third Party Access provided by Privacy Analytics, Inc.. ${ }^{256}$ They also helped develop the test cases for the pilot stage of the implementation plan.

The second engagement approach entails broader outreach to the public for their input. Thus, the Implementation Plan and Data Strategy Advisory Council each have their own webpage in which they post all public documents, meeting minutes and presentation slides. They have also hosted webinars, open to the public, on the Implementation Plan. The Advisory Council has published online correspondence regarding stakeholder consultations (with the permission of the stakeholders that provided the original feedback).

The Third Party Access Implementation Plan, provided by the SME to the OEB in their 2016 license renewal application, stipulates 5 phases. Phase 1, from Q4 of 2016 to Q2 of 2017, includes the collection of the four enhanced data elements as required by the OEB order (this stage has been completed). Additionally, Phase 1 includes the development of the legal agreement, business processes and functional and non-functional system application requirements to support the administration and provision for third party access services, privacy assessments and re-identification risk assessments for third party access, development of communication stakeholder plans, a training plan on how to use third party access tools, the establishment of an enhanced data governance framework, and the development of metrics to measure the success of pilot projects (in coordination with collaborating organizations).

\footnotetext{
255 http://www.ieso.ca/sector-participants/smart-metering-entity/data-strategy-advisory-council

${ }^{256}$ http://www.ieso.ca/-/media/files/ieso/document-library/smart-metering-entity/dsac/dsac-20170802-thirdparty-access-to-deidentified-data-roadmap.pdf?la=en
} 
Phase 2 includes the procurement of all necessary systems/applications, services and additional personnel, creation of training material for all aspects of the third party access services, an outline of complete business process to be utilized for providing third party access services, extension of the communications plan from Phase 1, and development of the Third Party Access Pilot Plan. This last task requires planning a timeline, selecting criteria for pilot participants, defining measures of success, evaluating process and limitations based on types of information requests.

Phase 3 includes preparing for the pilot program with selected participants. Test cases have been put forth by the Data Strategy Advisory Council and are provided in Table 11. This stage will test out the systems/applications and external services, finalize legal agreements between the SME and third parties collaborating on the pilot program. This Phase also includes a reassessment by Privacy Analytics Inc. of their original recommendations after new data elements have been collected for at least six months.

Table 11 - Test Cases (Source: http://www.ieso.ca/-/media/files/ieso/documentlibrary/engage/tpa/sme-third-party-access-presentation-20171107.pdf?la=en)

\begin{tabular}{l|l}
\hline \multicolumn{1}{c|}{ Organization } & \multicolumn{1}{c}{ Objective } \\
\hline City of Guelph & $\begin{array}{l}\text { To identify priority areas for EE/DG programs via energy mapping; } \\
\text { support GHGs targets with an emissions inventory }\end{array}$ \\
\hline Oxford County & $\begin{array}{l}\text { To create an accurate electricity baseline for improving EE, and aiding in } \\
\text { the transition to renewable energy. }\end{array}$ \\
\hline Enbridge Gas & $\begin{array}{l}\text { To establish load profiles to help predict the GHGs impact of the power } \\
\text { system and support emission reduction }\end{array}$ \\
\hline Ontario Clean & $\begin{array}{l}\text { To identify energy saving opportunities for the } 800 \text { water and } \\
\text { wastewater treatment /distribution /collection facilities }\end{array}$ \\
\hline IESO & $\begin{array}{l}\text { To improve short \& long term demand forecasting through better system } \\
\text { modelling }\end{array}$ \\
\hline OEB & $\begin{array}{l}\text { To better understand small commercial energy use patterns and to make } \\
\text { more informed pricing decisions }\end{array}$
\end{tabular}

Phase 4 will entail selecting participants for the pilot and monitoring operations to determine if any adjustments to the system, process, and legal agreement are necessary. The pilot program will conclude with a financial and an operations report. The operations report will assess the project based on predetermined key performance indicators. A financial report will itemize program costs by the categories indicated in the Assessment of Cost implications. Finally, Phase 5, extending into 2019, will open up data service offerings to new applicants. The SME states in their plan that they will monitor the overall service and will adopt continuous improvement practices for the long term. The SME intends to develop a training and communications strategy to make sure that the process and use of resources are clear to stakeholders. 
In August of 2017, Privacy Analytics, Inc. presented to the Data Strategy Advisory Council the Third Party Access to De-identified Data Roadmap, developed in consultation with the IESO ${ }^{257}$ The Roadmap provides an options analysis for:

(1) MDM/R de-identified data offering types,

(2) the provision of risk assessment and de-identification of data offerings, and

(3) technology platforms to request and deliver MDM/R de-identified data.

Its recommendations for the SME are divided across three categories of people, process, and technology. All of these are intended to support the SME's broader data governance framework. In addition to privacy, data sharing is expected to respond to principles of ethics, fairness, and the determination of what uses of the data are acceptable. Thus, the Roadmap recommended the IESO establish a Data Access and Ethics Review Committee as part of their process to provide the data for third party access. SME will develop a detailed project plan that incorporates the recommendations outlined in the Roadmap.

A member of Canada's National Research Council asked the SME if it is considering providing aggregated data as open data, to be released on the Provincial Open Data website. The SME responded they are aware of this type of data offering. However, the SME is still contemplating how specifically to provide the de-identified data for third party access. The suggestions of MNP, the firm selected to provide consultant services to assist in developing a Market Analysis \& Costing Model for third party access to de-identified electricity consumption data, does not include the option of open data in a presentation to the Data Strategy Advisory Council. MNP's model includes collecting and interpreting economic and financial information specific to the use and value of data in various sectors and for various types of purposes, a detailed analysis and modeling based on market and business inputs, and viable options for a model that will support IESO's future policy of charging various third parties using and accessing the de-identified electricity data. ${ }^{258}$ The MNP identified and presented to the Data Strategy Advisory Council the pricing model alternatives for accessing and using the meter data.

Decisions about the Third Party Access Implementation Plan, such as the type of data offering and costing model for meter data, will be informed by lessons from the test cases and be made throughout 2018.

\footnotetext{
${ }^{257}$ http://www.ieso.ca/-/media/files/ieso/document-library/smart-metering-entity/dsac/dsac-20170802-thirdparty-access-to-deidentified-data-roadmap.pdf?la=en 258 http://www.ieso.ca/-/media/files/ieso/document-library/smart-metering-entity/dsac/dsac-20180131-costingmodel-update.pdf?la=en
} 


\subsubsection{The Green Button Initiative}

The Green Button Initiative has made it possible to share with customers their own energy use data from meter readings. The Ontario Green Button program is an initiative led by the MaRS Discovery District ${ }^{259}$ and supported by government, utility companies, and private industry actors to provide common data access standards for Ontario's smart meter data ${ }^{260}$. The Green Button initiative, which was originally an initiative by the U.S. Department of Energy, allows electricity customers to access their energy consumption data via an open standard. ${ }^{261}$ The standard allows customers to consent and control with regards to whom they share data about their energy use. Technical documentation about the Green Button consensus-based standards is available online.

The "Green Button" is a suite of standards that are characterized by the following components: (1) A data access standard, "Download my Data", that represents a common data format (see Figure 27) and (2) the Energy Service Provider Interface (ESPI), entitled "Connect my data" (see Figure 28), that provides a consistent way for customers to grant and revoke third party access to their data and automatically provide it to applications $^{262}$. Documentation about these standards was published in collaboration with the Smart Grid Interoperability Panel $^{263}$ to enable applications for the data so that customers may be better informed about their energy use in real time. The ESPI, published by the National

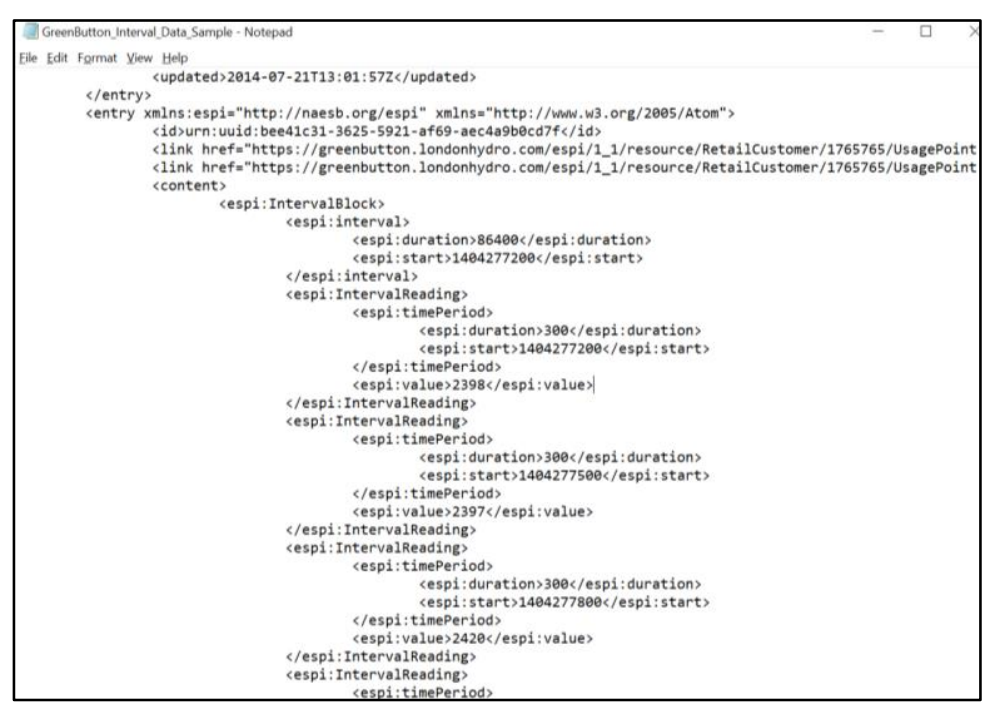

Figure 27 - Example of Download my Data Schema

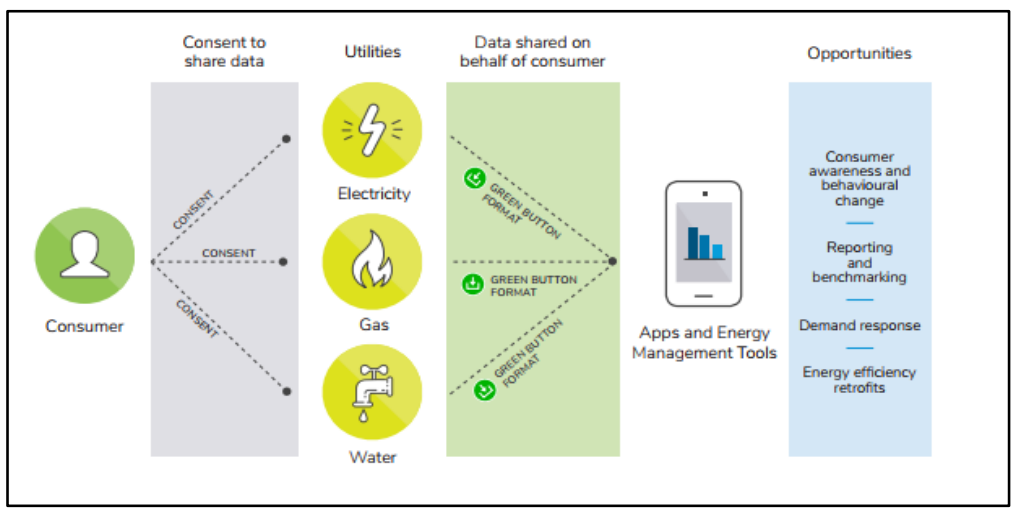

Figure 28 - Green Button Connect My Data (Source: Ontario's 2017 Long Term Energy Plan: Delivering Fairness and Choice, p. 99)

\footnotetext{
259 https://www.marsdd.com/

260 http://www.greenbuttondata.ca/

261 https://openei.org/wiki/Green Button Developer\#ESPI Toolkit

262 http://www.ieso.ca/learn/ontario-power-system/a-smarter-grid/ontario-smart-grid-forum/Lmedia/files/ieso/document-library/smart grid/Smart Grid Progress Assessment Vignette.pdf 263 http://collaborate.nist.gov/twiki-sggrid/bin/view/SmartGrid/WebHome
} 
American Energy Standards Board (NAESB), is a standardized process and interface for the exchange of a retail customer's energy use information between their designated data custodian (i.e. distribution company) and an authorized third party service provider. ${ }^{264}$ An example of energy use data that implements the ESPI XML schema is provided in Figure 27.

Ontario's Green Button program has a list of energy hackathon resources (data, APIs, examples) for web hacks and energy mashups by application developers. ${ }^{265}$ According to the Smart Grid Forum's Assessment Report ${ }^{262}$ published in 2013, over 2.6 million retail customers were able to access their smart metering data in Green Button format. The format has enabled a variety of software applications that display and analyze a customer's energy use data.

\subsubsection{Summary}

Cities in Ontario shape how smart meter data, meters and smart grid technology are managed, but do so at a distance via their participation or representation in formal committees, such as the Data Strategy Advisory Council. While LDCs manage electricity that is distributed and metered in cities, the management of Ontario's electricity systems is directed by the IESO and regulated by OEB. Costumers of LDCs may access data on their energy use via their billing and the Green Button, a system that enables customers to decide whether or not to share their energy use data with third party services. Data are also aggregated and deposited and stored in the MDM/R repository and managed by the SME. The governance of the implementation plan to allow third party access to Ontario's smart meter data is carried out by an Executive Steering Committee and informed by experts represented on the Data Strategy Advisory Council. The external consultation process was extensive, as was the pilot and the audit trail to ensure privacy. This is an excellent example of professional, expert and government collaboration and the operationalization of privacy by design. The MDM/R data are expected to be made available for third party access by 2019. 2018 will include continuation of privacy and de-identification assessments and choosing the type of data offering and the costing model for meter data that is accessed and used by third parties.

\subsubsection{Inter-jurisdictional Collaboration and Smart Cities}

Allowing third parties to access de-identified smart meter data is expected to help municipalities in Ontario manage and measure their energy goals. The Ministry of Energy has interacted with cities or regional municipalities on smart city initiatives via grassroot energy initiatives. For instance, the City of Guelph has expressed a desire to become a net zero energy community. ${ }^{266}$ However, such expressions are ad-hoc/opportunistic and the more comprehensive mechanisms do not appear to be in place at the Ministry of Energy to collaborate with cities on smart city programs and projects.

\footnotetext{
264 https://www.naesb.org//ESPI Standards.asp

265 https://openei.org/wiki/Help:Energy Hackathon Resources

${ }^{266}$ https://globalnews.ca/news/3230464/londons-net-zero-west-5-smart-community-expected-to-be-move-inready-for-spring/
} 
It is unknown if inter-jurisdictional partnerships to promote data driven energy management are informing or accelerating smart city initiatives in Ontario. The Smart Grid Forum ${ }^{267}$ is an interjurisdictional mechanism (in that it consists of provincial and municipal representatives) to develop the smart grid in Ontario, but there is not any evidence suggesting smart cities are discussed among its members. Furthermore, the Ontario Ministry of Energy's 2017 Long Term Energy Plan: Delivering Fairness and Choice mentions coordination among municipalities, LDCs, and other government agencies to enable a knowledge sharing platform and partnerships to increase efficiencies of scale and scope within operations of individual LDCs (e.g., the GridSmartCity Cooperative). However, direct linkages to smart city strategies by municipalities are not discussed in the Plan. There is also a branch at the Ministry of Energy that works on supplying funding to municipal energy planning, but it is unknown whether smart city solutions are considered during the process to secure funding. Efficiency standards on municipal energy practices, enforced by the Ministry, do require inter-jurisdictional cooperation and necessitate information sharing. However, it is not evident yet if provincial compliance standards impact, link, or accelerate smart city programs in Ontario.

${ }^{267}$ http://www.ieso.ca/learn/ontario-power-system/a-smarter-grid/ontario-smart-grid-forum//media/files/ieso/document-library/smart grid/Smart Grid Progress Assessment Vignette.pdf 
Appendix A: Edmonton's Smart City Strategy (2017)

\begin{tabular}{|c|c|c|c|}
\hline $\begin{array}{l}\text { Smart City } \\
\text { Goals }\end{array}$ & $\begin{array}{l}\text { Smart City } \\
\text { Components }\end{array}$ & Actions & Related Smart City Initiatives \\
\hline \multirow[t]{3}{*}{ Resiliency } & Open City & $\begin{array}{l}\text { Align practices to support openness, transparency, and } \\
\text { consistency } \\
\text { Create opportunities for citizens to interact with the City and } \\
\text { impact the design, development and delivery of public programs, } \\
\text { services, and policies } \\
\text { Enhance quality and increase quantity of information available } \\
\text { via the open data strategy } \\
\text { Provide information to Edmontonians to promote participation } \\
\text { and collaboration, increase knowledge, and build capacity in the } \\
\text { community } \\
\text { Support informed policy development and decision-making by } \\
\text { leveraging the vast stores of city data and new analytics } \\
\text { capabilities }\end{array}$ & $\begin{array}{l}\text { Open Data } \\
\text { Citizen Dashboard } \\
\text { Open Analytics } \\
\text { The Metro Edmonton Open Data } \\
\text { Group }\end{array}$ \\
\hline & Citizens & $\begin{array}{l}\text { Develop strategies to evaluate methods of citizen engagement that } \\
\text { are most appropriate to discuss issues facing the city now and in } \\
\text { the future } \\
\text { Consider the unique characteristics and needs of minority groups } \\
\text { to inform developing strategies to address these needs } \\
\text { Understand the issues and challenge facing the youth of today } \\
\text { and tomorrow } \\
\text { Ensure consistent access to programs and service for all Citizens }\end{array}$ & $\begin{array}{l}\text { Online Engagement } \\
\text { The Edmonton Insight Community } \\
\text { Indigenous Inclusion } \\
\text { Youth Council } \\
\text { Council Initiative on Public } \\
\text { Engagement } \\
\text { Idea generator } \\
\text { Edmonton Service Centre }\end{array}$ \\
\hline & Economy & $\begin{array}{l}\text { Support a competitive business climate an deliver business } \\
\text { friendly services } \\
\text { Facilitate the development of established businesses and sectors } \\
\text { Support the advancement of potential sectors } \\
\text { Attract talent and investment } \\
\text { Lead and participate in effective regional partnerships and } \\
\text { collaboration }\end{array}$ & $\begin{array}{l}\text { Edmonton Economic Development, } \\
\text { TEC Edmonton, Startup Edmonton, } \\
\text { Alberta Innovates, eHub, Edmonton } \\
\text { International Airport, Alberta Women } \\
\text { Entrepreneurs, Edmonton Research } \\
\text { Park }\end{array}$ \\
\hline \multirow[t]{2}{*}{ Livability } & Health & $\begin{array}{l}\text { Develop and implement a strategy to end poverty in Edmonton } \\
\text { Address the challenges facing Canada's health industry }\end{array}$ & $\begin{array}{l}\text { End Poverty Edmonton Strategy, } \\
\text { Health City Initiative }\end{array}$ \\
\hline & Community & $\begin{array}{l}\text { Utilize place making to foster relationships, collaboration, } \\
\text { experimentation and innovation }\end{array}$ & Make Something Edmonton, CITYlab \\
\hline
\end{tabular}




\begin{tabular}{|c|c|c|c|}
\hline & & $\begin{array}{l}\text { Engage in conversations about how Cities evolve, how to connect } \\
\text { people } \\
\text { Promote broad cultural and artistic investment across all aspects } \\
\text { of cultural spectrum }\end{array}$ & $\begin{array}{l}\text { Edmonton's Infill Roadmap, } \\
\text { Edmonton Arts Council, } \\
\text { BetaCityYEG, Fresh }\end{array}$ \\
\hline & Environment & $\begin{array}{l}\text { Ensure sustainable energy source and uses } \\
\text { Implement practices to ensure Edmonton is resilient to } \\
\text { disturbance that are capable of affecting its energy supplies and } \\
\text { distribution systems } \\
\text { Become a carbon-neutral city } \\
\text { Ensure the city is pollution free and environment friendly }\end{array}$ & $\begin{array}{l}\text { Energy transition Strategy Blatchford } \\
\text { Enerkem Facility } \\
\text { Touch the Water Promenade } \\
\text { Edmonton Waste Management Centre }\end{array}$ \\
\hline \multirow[t]{3}{*}{ Workability } & Mobility & $\begin{array}{l}\text { Promote collaboration between citizen and administrations } \\
\text { through digital equality and accessibility } \\
\text { Encourage the identification of innovative idea from citizens and } \\
\text { staff to improve the delivery of programs and services } \\
\text { Harness new technologies as they become available } \\
\text { Set a framework for building a sustainable, modern city that meets } \\
\text { the needs of Edmonton urban and regional population }\end{array}$ & $\begin{array}{l}\text { Smart Bus } \\
\text { Autonomous Vehicles } \\
\text { Centre for Smart Transportation } \\
\text { Intelligent Transportation } \\
\text { Smart Fare }\end{array}$ \\
\hline & Education & $\begin{array}{l}\text { Partner with universities and colleges to share ideas and } \\
\text { knowledge on city data and systems } \\
\text { Promote Edmonton as a post-secondary city to encourage future } \\
\text { investment and sector growth } \\
\text { Facilitate digital inclusion and literacy among all citizens } \\
\text { Collaborate with education institutions to demonstrate the } \\
\text { possibilities and prepare students for advancement in technologies } \\
\text { and data analysis }\end{array}$ & $\begin{array}{l}\text { Open Science } \\
\text { Edmonton Public Library Digital } \\
\text { Literacy }\end{array}$ \\
\hline & Infrastructure & $\begin{array}{l}\text { Work with utility partners to provide smart energy and water } \\
\text { metering } \\
\text { Upgrade our road networks with smart technologies to ensure } \\
\text { adequate management of existing assets } \\
\text { Upgrade our ICT infrastructure to ensure high speed connectivity } \\
\text { Build sustainable and connected future communities } \\
\text { Smart building to manage infrastructure demand density }\end{array}$ & $\begin{array}{l}\text { Open City Wifi } \\
\text { EPCOR } \\
\text { Vision Zero initiative } \\
\text { Soofa Benches installations } \\
\text { Telus PureFibre } \\
\text { EPark } \\
\text { Civic Smart Card } \\
\end{array}$ \\
\hline
\end{tabular}


Appendix B: Ottawa's Smart City 2.0 (2017)

\begin{tabular}{|c|c|c|c|c|}
\hline $\begin{array}{c}\text { Smart City } \\
\text { Goals }\end{array}$ & Description & $\begin{array}{l}\text { Categories of } \\
\text { Initiatives }\end{array}$ & Sampled Initiatives & Collaborative Stakeholders \\
\hline \multirow{13}{*}{$\begin{array}{l}\text { Connected } \\
\text { City }\end{array}$} & \multirow{13}{*}{$\begin{array}{l}\text { Create a city } \\
\text { where all } \\
\text { residents and } \\
\text { businesses are } \\
\text { connected in an } \\
\text { efficient, } \\
\text { affordable, and } \\
\text { ubiquitous way. }\end{array}$} & \multirow{5}{*}{$\begin{array}{l}\text { Build next generation } \\
\text { infrastructure }\end{array}$} & Develop a Fibre Broadband Strategy & Hydro Ottawa and industry stakeholders \\
\hline & & & $\begin{array}{l}\text { Support an Ottawa Internet Exchange } \\
\text { (IXP) (a carrier-neutral interchange } \\
\text { point, which would provide broader } \\
\text { bandwidth options to interconnect } \\
\text { Ottawa users with other Canadians) }\end{array}$ & $\begin{array}{l}\text { Partners like the Canadian Internet } \\
\text { Registration Authority (CIRA) and Invest } \\
\text { Ottawa }\end{array}$ \\
\hline & & & Support a 5G Testbed & Invest Ottawa and CENGN \\
\hline & & & $\begin{array}{l}\text { Wireless Tower Lease/Attachment } \\
\text { and Fibre Backhaul }\end{array}$ & TBD \\
\hline & & & Smart Community Pilots & $\begin{array}{l}\text { City of Ottawa and NRC partner with land } \\
\text { developers and technology providers to } \\
\text { embed advanced technologies within new } \\
\text { development permits }\end{array}$ \\
\hline & & \multirow{3}{*}{$\begin{array}{l}\text { Sensors and Data (big } \\
\text { data, IoT, and } \\
\text { algorithms/analytics) }\end{array}$} & Expand sensor deployment & TBD \\
\hline & & & Connected LED Lighting & TBD \\
\hline & & & $\begin{array}{l}\text { Advance Ottawa's Leading Position } \\
\text { in Data Analytics }\end{array}$ & $\begin{array}{l}\text { Carleton University, the University of } \\
\text { Ottawa, Algonquin College, and Federal } \\
\text { Government }\end{array}$ \\
\hline & & \multirow{5}{*}{$\begin{array}{l}\text { Bridging the Digital } \\
\text { Divide }\end{array}$} & Explore Broadband as a Utility & TBD \\
\hline & & & $\begin{array}{l}\text { Explore a Minimum Connectivity } \\
\text { Standard }\end{array}$ & Industry partners \\
\hline & & & $\begin{array}{l}\text { Explore a Minimum Connectivity } \\
\text { Standard }\end{array}$ & Industry partners \\
\hline & & & $\begin{array}{l}\text { Investigate Further Options for Low- } \\
\text { Cost Broadband }\end{array}$ & TBD \\
\hline & & & Extend Public Wi-Fi & TBD \\
\hline
\end{tabular}




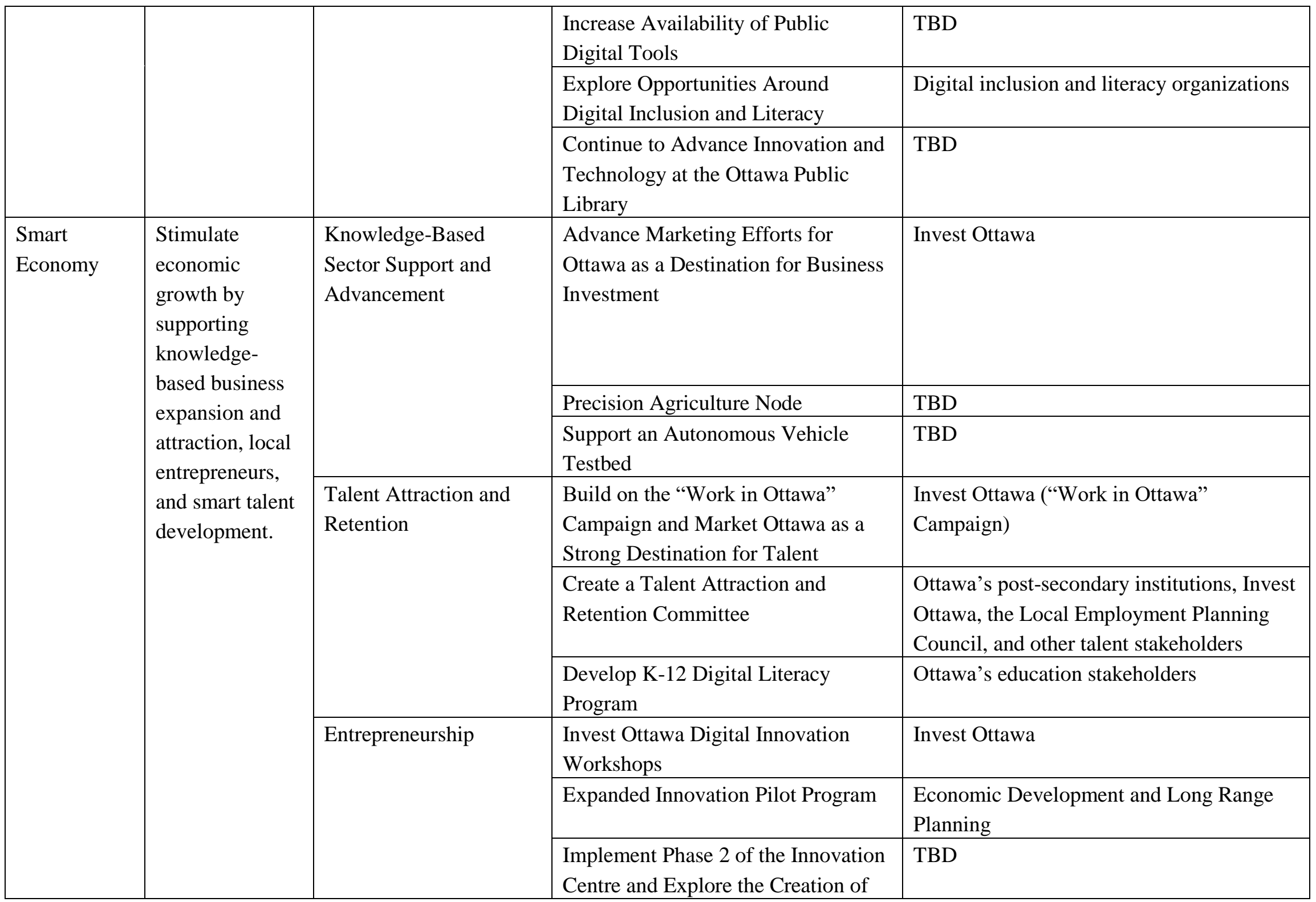




\begin{tabular}{|c|c|c|c|c|}
\hline & & & $\begin{array}{l}\text { an Innovation District at Bayview } \\
\text { Yards }\end{array}$ & \\
\hline \multirow[t]{8}{*}{$\begin{array}{l}\text { Innovative } \\
\text { Government }\end{array}$} & \multirow{8}{*}{$\begin{array}{l}\text { Develop new } \\
\text { and innovative } \\
\text { ways to impact } \\
\text { the lives of } \\
\text { residents and } \\
\text { businesses } \\
\text { through the } \\
\text { creative use of } \\
\text { new service } \\
\text { delivery models, } \\
\text { technology } \\
\text { solutions, and } \\
\text { partnerships. }\end{array}$} & \multirow[t]{3}{*}{$\begin{array}{l}\text { Digital Service Strategy } \\
\text { (DSS) }\end{array}$} & $\begin{array}{l}\text { Delivering a Mobile Client } \\
\text { Experience }\end{array}$ & TBD \\
\hline & & & $\begin{array}{l}\text { Analytics driven, responsive } \\
\text { operations enabled by machine } \\
\text { learning, artificial intelligence, } \\
\text { predictive analytics, and open data }\end{array}$ & TBD \\
\hline & & & $\begin{array}{l}\text { Intelligent infrastructure via OC } \\
\text { Real-Time Transit Service } \\
\text { Information, Light Rail Transit } \\
\text { (LRT), Traffic Operations, } \\
\text { Automated Meter Reading project, } \\
\text { sensors, Ottawa Fire Services }\end{array}$ & TBD \\
\hline & & \multirow[t]{5}{*}{ Innovative Government } & $\begin{array}{l}\text { Enable a Mobile Driven Digital } \\
\text { Experience }\end{array}$ & TBD \\
\hline & & & $\begin{array}{l}\text { Enhance Ottawa's Open Data } \\
\text { Program }\end{array}$ & TBD \\
\hline & & & $\begin{array}{l}\text { Implement Additional Service } \\
\text { Delivery Analytics }\end{array}$ & TBD \\
\hline & & & $\begin{array}{l}\text { Explore Pilot(s) for Artificial } \\
\text { Intelligence, Predictive Analytics, } \\
\text { and Machine Learning }\end{array}$ & TBD \\
\hline & & & $\begin{array}{l}\text { Engage Ottawa's Knowledge-Based } \\
\text { Sector and Eco-System in the } \\
\text { Delivery of Smart City Solutions via } \\
\text { studying new procurement models }\end{array}$ & TBD \\
\hline
\end{tabular}

